Arch. histol. jap. Vol. 29, No. 2 (1968)

p. $137-192$

Department of Anatomy (Prof. T. Iто)

Gunma University School of Medicine, Maebashi, Japan

\title{
Electron Microscopic Study on the Hepatic Sinusoidal Wall and the Fat-Storing Cells in the Normal Human Liver
}

\author{
Toshio Ito and Susumu Shibasaki \\ (伊東俊夫と柴崎晋) \\ Received January 19, 1968
}

Numerous electron microscopic studies have been carried out to elucidate the structural characteristics of the hepatic sinusoidal wall (Novikoff and Essner 1960, Aterman 1963, Roulller et al. 1963, Tanikawa et al. 1965, Kuhn et al. 1965, Bronfenmajer et al. 1966, Sahnack, Stockinger and Wewalka 1966, Safran and Sahaffner 1967, Nigolescu and Rouiller 1967, etc.). Owing to these electron microscopic studies it has been revealed that the hepatic sinusoidal wall is composed of the continuous or discontinuous endothelial lining including the Kupffer cells associated with or without the basement membrane and the sinusoidal surfaces of the hepatocytes and that between these two elements there exists the perisinusoidal space or the Disse's space, in which an amorphous material similar to blood plasm, collagen or reticular fibers and abundant microvilli protruded from the hepatocytes are commonly contained. Besides these contents, the occurrence of unmyelinated nerve fibers (YAMADA 1965), pericytes, fat-storing cells and other cell types have been proposed. The "fat-storing cell" ("Fettspeicherungs- or Fettspeicherzelle") was discovered and for the first time reported by Iто (1950) at the 55th Annual Meeting of the Japanese Association of Anatomist and thereafter described in detail by Іто and Neмото (1952). According to numerous light microscopic observations carried out by Іто and his co-workers on the liver of several mammals, birds, reptiles, amphibia and fishes, the fat-storing cells are located, contrary to endothelial and Kupffer cells, within the sinusoidal wall being separated by reticular fibers from the sinusoidal lumen. They contain in the cytoplasm fat droplets blackend by osmic acid which exhibit the morphological characteristics strictly different from species to species; for example fat-storing cells of human livers always possess, without any individual variations, many small, closely packed fat droplets, the same pattern of fat droplets of the fat-storing cells is found in the livers of several rodents, horses and of many birds. In the calf, pig, goat, whale and snake the morphology of fat droplets in fat-storing cells is quite different; they always contain a single large fat droplet in the cells. Another type of fat droplet is observed in the carnivore, the cat and dog. They contain commonly small numbers of medium sized fat droplets in these cells of the liver. In 1959 YAMAGishi observed for the first time fat-storing cells by means of electron microscopy in the rabbit liver and revealed that they are present in the perisinusoidal or Disse's space and that, as proved by light microscopy, they never directly face the sinusoidal lumen being separated by the endo- 
thelial lining from the latter. This electron microscopic study was important, because it has accurately established the existence of the fat-storing cell, which is different in localization, ultrastructure and function from the endothelial and Kupffer cells, in the hepatic sinusoidal wall. Following this author, several workers have electron microscopically observed the fat-storing cells in human and animal livers (Novikoff and Essner 1960, Nakane 1963, Roulller et al. 1963, Tanikawa et al. 1965, Bronfenmajer et al. 1966, Sahnack, Stogkinger and Wewalka 1966, Nigolescu and Rouiller 1967, etc.) but regarding their functional significance and identity with other cell types there exists opinion divergency. In his review on hepatic sinusoid, Aterman (1963) pointed out that obviously the question of "pericytes", extravascular "reticular cell" or "fat-storing cells" is quite unsettled and requires much further research if we are to arrive at definite views concerning the potential for extramedullary hemopoiesis or formation and maintenance of connective tissue fibers in the liver parenchyme. In the present study the authors have attempted an electron microscopic observation on the hepatic sinusoidal wall and especially on the fat-storing cells of normal human livers to add some new findings which may contribute to the solution of several questions concerning this research field.

\section{Materials and Methods}

The materials used for this study were small pieces of the livers removed surgically from patients suffering from the gastric ulcer at the time of the operation. Small blocks of tissue were promptly dipped into chilled $1 \% \mathrm{OsO}_{4}$ of $\mathrm{C}_{\text {AULfield }}$ in the operating room, then they were cut into many smaller pieces in the laboratory room and refixed in the same fixative for about 90 minutes at $4{ }^{\circ} \mathrm{C}$. The specimens were rapidly dehydrated with ascending serial concentrations of ethanol for about 10 minutes in each step, and embedded in Epon 812 according to the method of LufT (1961). Thick sections stained with toluidine blue served for the determination of the presence of "fat storing cells". For electron microscopy, thin sections on copper grids were double-stained with uranyle acetate and lead hydroxide. After these procedures they were examined and photographs were taken in the JEM-5G type or the JEM-7 type electron microscope.

\section{Results}

Perisinusoidal space. The hepatic sinusoid is surrounded by a continuous, electron lucent perisinusoidal space or a Disse's space of variable width which is sandwitched between the endothelial cells lining directly the sinusoidal lumen and the sinusoidal or perisinusoidal surface of the hepatic parenchymal cells or hepatocytes. The latter protrude, as revealed for the first time by FAWGETT (1955), numerous polymorphous microvilli into the perisinusoidal space (Fig. 1, 2,3). As described by several workers, from the perisinusoidal space wedge-shaped recesses extend at different intervals between the adjacent hepatocytes for considerable distances approaching the bile canaliculi, from which they are, however, completely separated by a terminal bar formed between apposed hepatocytes. The free surfaces of the adjacent hepatocytes bordering the recesses protrude also microvilli into the latter ; occasional desmosomes 


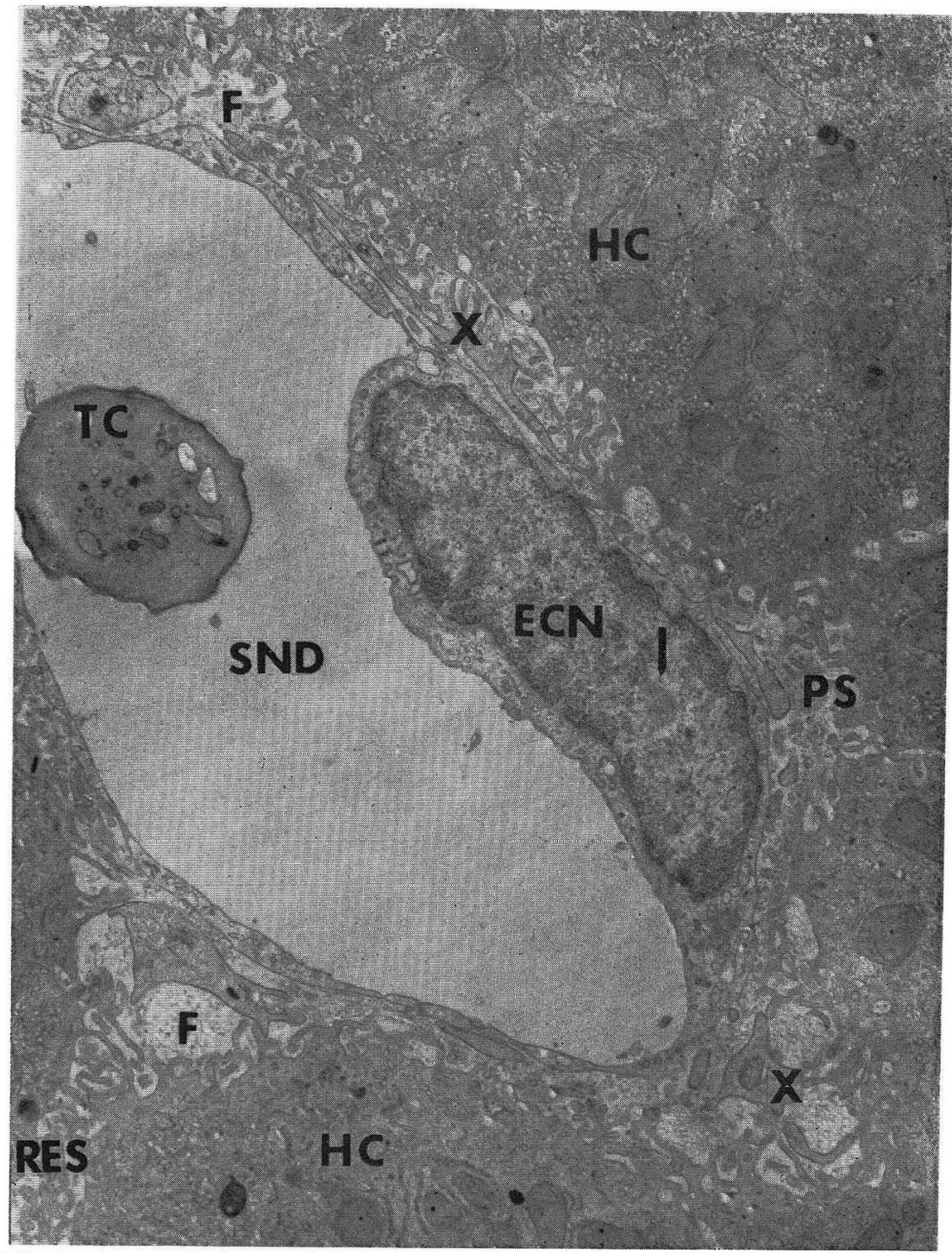

Fig. 1. A survey picture of the hepatic sinusoid $(S N D)$ and the perisinusoidal space (Disse's space) $(P S)$. The hepatic sinusoid is lined by the perikaryon containing an elongated nucleus $(E C N)$ and the thin cytoplasmic sheet of the endothelial lining ccll, which shows a pore or gap. The perisinusoidal space $(P S)$ between the endothelial lining cells and the perisinusoidal surfaces of the hepatocytes $\left(H C^{\prime}\right)$ contains abundant microvilli of the hepatocytes and collagen fibers $(F)$. Several short cytoplasmic sheets or portions $(X)$ closely and in parallel apposed to the outside of the endothelial lining are subendothelial processes of the fat-storing cells. The nucleus $(E C N)$ of the endothelial cell contains a sphaeridion (arrow). RES recessus of perisinusoidal space, $T C$ blood platelet. $\times 9,000$ 


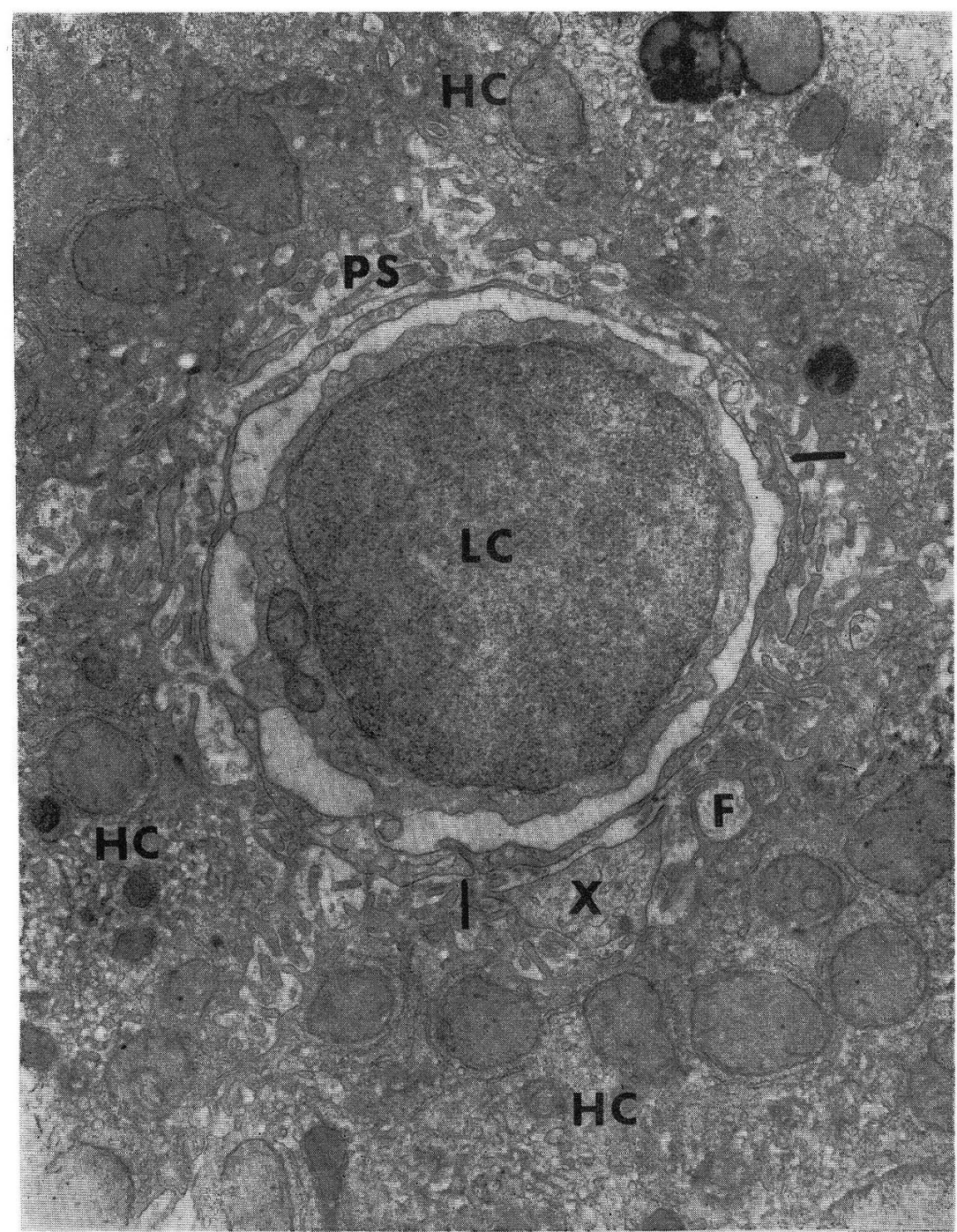

Fig. 2. Endothelial cell shects lining a sinusoid containing a lymphocyte $(L C)$ and the perisinusoidal space $(P S)$ containing hepatocytic microvilli and collagen fibers $(F)$. Between adjoining endothelial sheets two cell connections (arrovs) are seen in which overlappings of the endothelial sheets are clearly visible, in the endothelial sheet a gap is seen. $H C$ hepatocytes, $X$ subendothelial process or cytoplasmic portion of the fat-storing cell. $\times 15,600$

are seen at the places where the free surfaces of the adjacent hepatocytes closely approach each other (Fig. 1, 2, 3).

Endothelial lining cells. The identity of endothelial lining cells and the Kupffer cells has been discussed by many investigators, and recently the view that they might probably represent two functional states of the same cell lineage, may seemingly predominate. In this place, however they will be provisionally, for the sake 


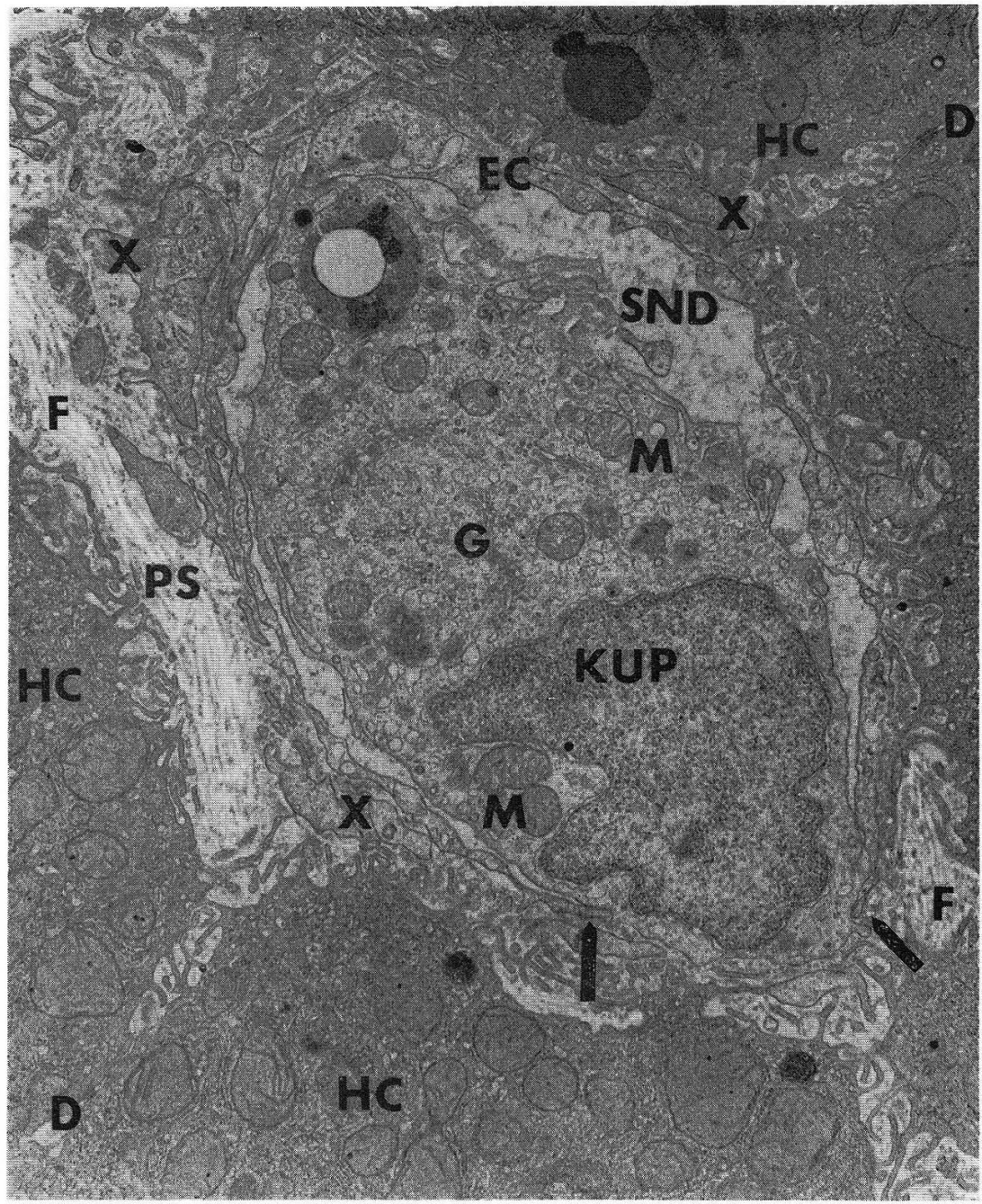

Fig. 3. A Kupffer cell $(K U P)$ projecting extensively into the sinusoid $(S N D)$, which lines directly the perisinusoidal space, with the bottom right corner of the cell body sending out a short microvillus-like process into the latter. The connections between the Kupffer cell and the endothelial sheet $(E C)$ lining the sinusoid are seen at two arrows. The Kupffer cell has an irregularly shaped nucleus, well-developed Golgi complex $(G)$, numcrous mitochondria $(M)$ and dense bodics. The collagen fibers $(F)$ in the perisinusoidal space represent bundles of closely packed collagen fibriles. $H C$ hepatocytes, $X$ subendothelial processes or cytoplasmic portions of fat-storing cells. $\times 6,900$

of convenience, described as two different cell types.

The cell body or perikaryon of the endothelial lining cell of the hepatic sinusoid shows in general a spindle-shaped profile projected to some extent into the sinusoidal lumen (Fig. 1, 4, 5) ; it contains an elongated or rod-shaped nucleus which possesses a small nucleolus composed of nucleolonema and sometimes one or two spherules of 


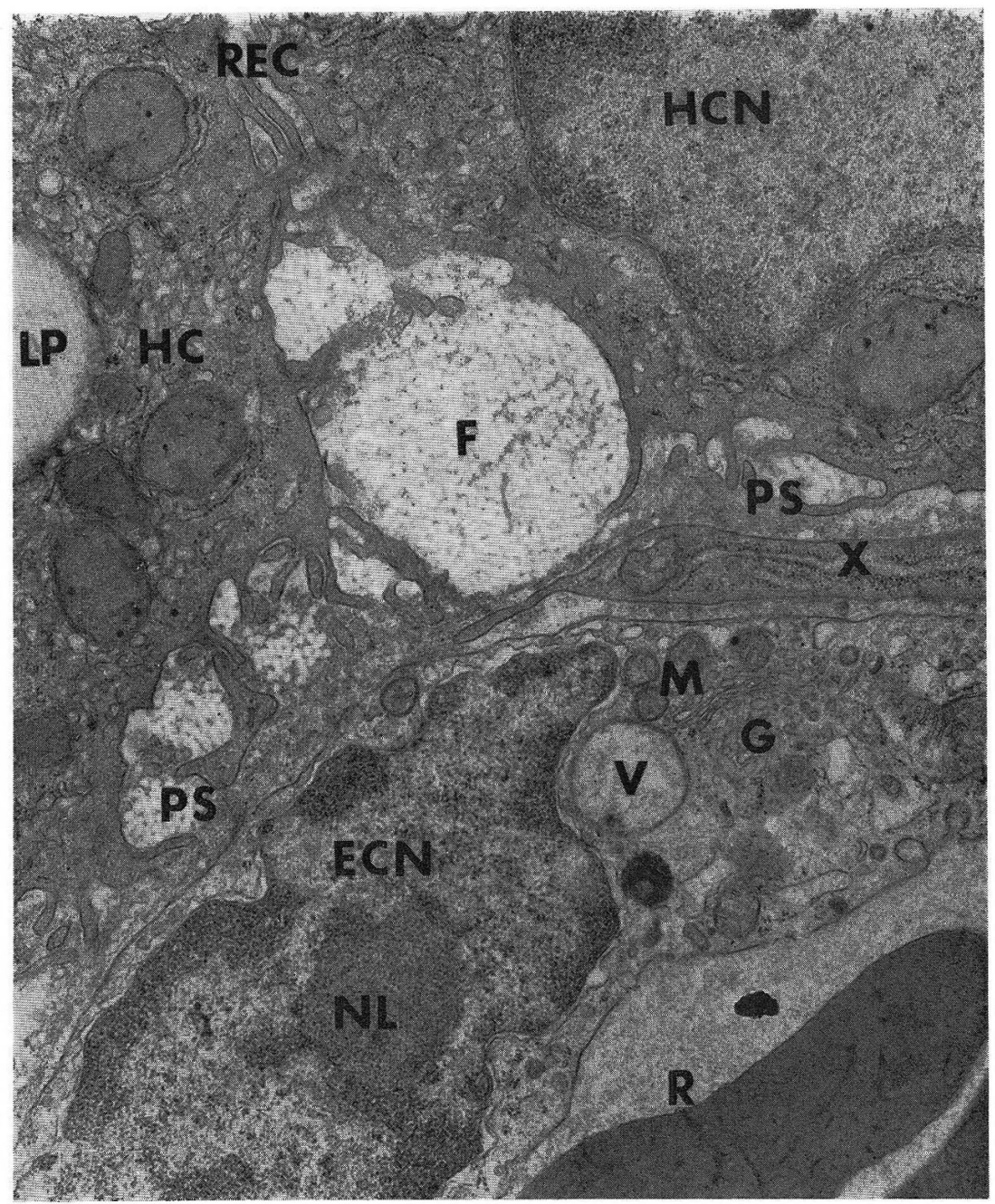

Fig. 4. The perikaryon of an endothelial lining cell and the perisinusoidal space with a recessus $(R E C)$ extending between the adjoining hepatocytes. In the perikaryon, on one side of the nucleus $(E C N)$ containing nucleolus $(N L)$, a Golgi complex $(G)$, mitochondria $(M)$, a large vacuole $(V)$ and a dense body (lysosome) are seen. Along the plasma membrane facing the sinusoid many small pinocytotic invaginations and vesicles are visible, and some of them are coated ones. The perisinusoidal space (PS) contains cross sections of collagen fibers $(F)$ of variable thickness. $L P$ lipid droplet in hepatocyte $(H C), H C N$ nucleus of hepatocyte, $R$ erythrocyte in sinusoid, $X$ subendothelial process of fat-storing cell containing flattened sacs of granular endoplasmic reticulum and a small mitochondrion. $\times 10,000$

moderate electron density which may correspond to the "Sphaeridien" (sphaeridies) of BütTner and Horstmann (1967) (Fig. 1, 5). The chromatin material makes several densely packed accumulations along the nuclear envelope. The clear cytoplasmic layer around the nucleus is in general not so thick except for the paranuclear region where an accumulation of cytoplasm is commonly found. The round or rod-shaped 
mitochondria of the endothelial cells are smaller than those of the Kupffer cells. They are mainly distributed in the paranuclear cytoplasm, but less numerous than in the Kupffer cells (Fig. 4, 5). The Golgi apparatus of the endothelial cells is in general small, it consists of several short lamellae and vesicles and exists usually in close proximity to the nucleus (Fig. 4). The centriole in the endothelial cells of the hcpatic sinusoid has been observed for the first time by Yamagish (1959) in the rabbit liver. In the present study, however, we could not succeed in demonstrating it in the human liver. The granular endoplasmic reticulum is poorly developed; a small number of cisternae of irregular shapes are mainly scattered in the paranuclear cytoplasm and most of them are associated with mitochondria (Fig. 4, 5, 6). The free ribosomes are not numerous and the majority of them are aggregated into small

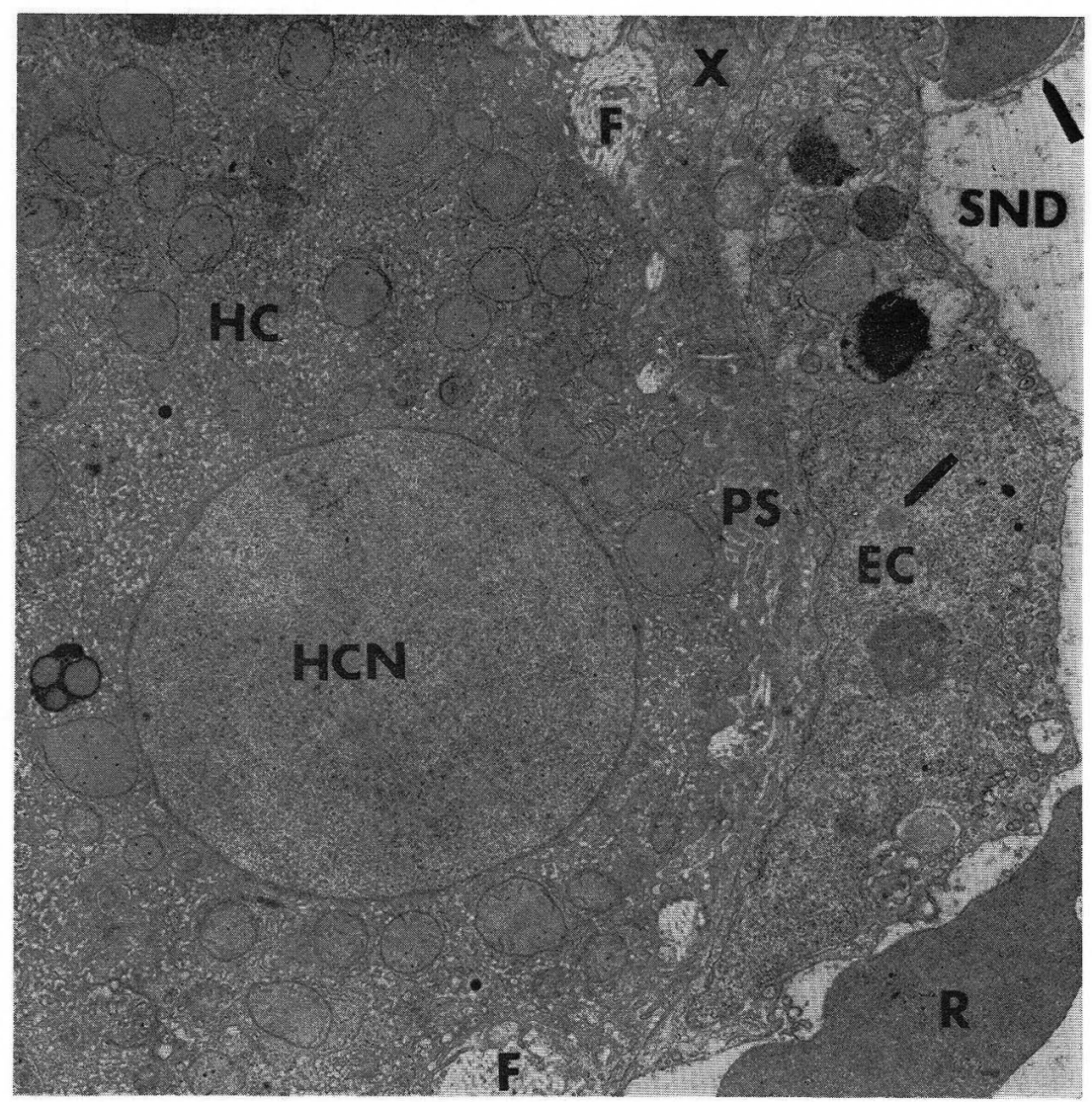

Fig. 5. A Perikaryon of the endothelial lining cell $(E C)$ and a hepatocyte, which are separated by perisinusoidal space $(P S)$ containing microvilli and collagen fibers $(F$, unstained). In the perikaryon there occur several vacuoles containing granular material (phagosomes) and small mitochondria. Along the sinusoidal surface numerous smooth vesicles are present. A slender cytoplasmic process (arrow) is protruded along the erythrocyte in the sinusoid $(S N D)$. In the nucleus, besides a nucleolus a sphaeridion (arrow) is seen. $H C$ hepatocyte, $H C N$ nucleus of hepatocyte, $R$ erythrocyte in sinusoid, $X$ cytoplasmic portion of a fat-storing cell. $\times 6,000$ 
clusters scattered at random throughout the cytoplasm. Smooth vesicles of variable sizes are also seen in the perinuclear and paranuclear cytoplasm. They vary widely in number from cell to cell (Fig. 1, 5, 6); among them some coated vesicles are found. The content within the vesicles is not uniform in density; some of them contain fine granular material (Fig.5). Along the plasma membrane lining both the sinusoidal and the perisinusoidal surfaces there appear pinocytotic invaginations

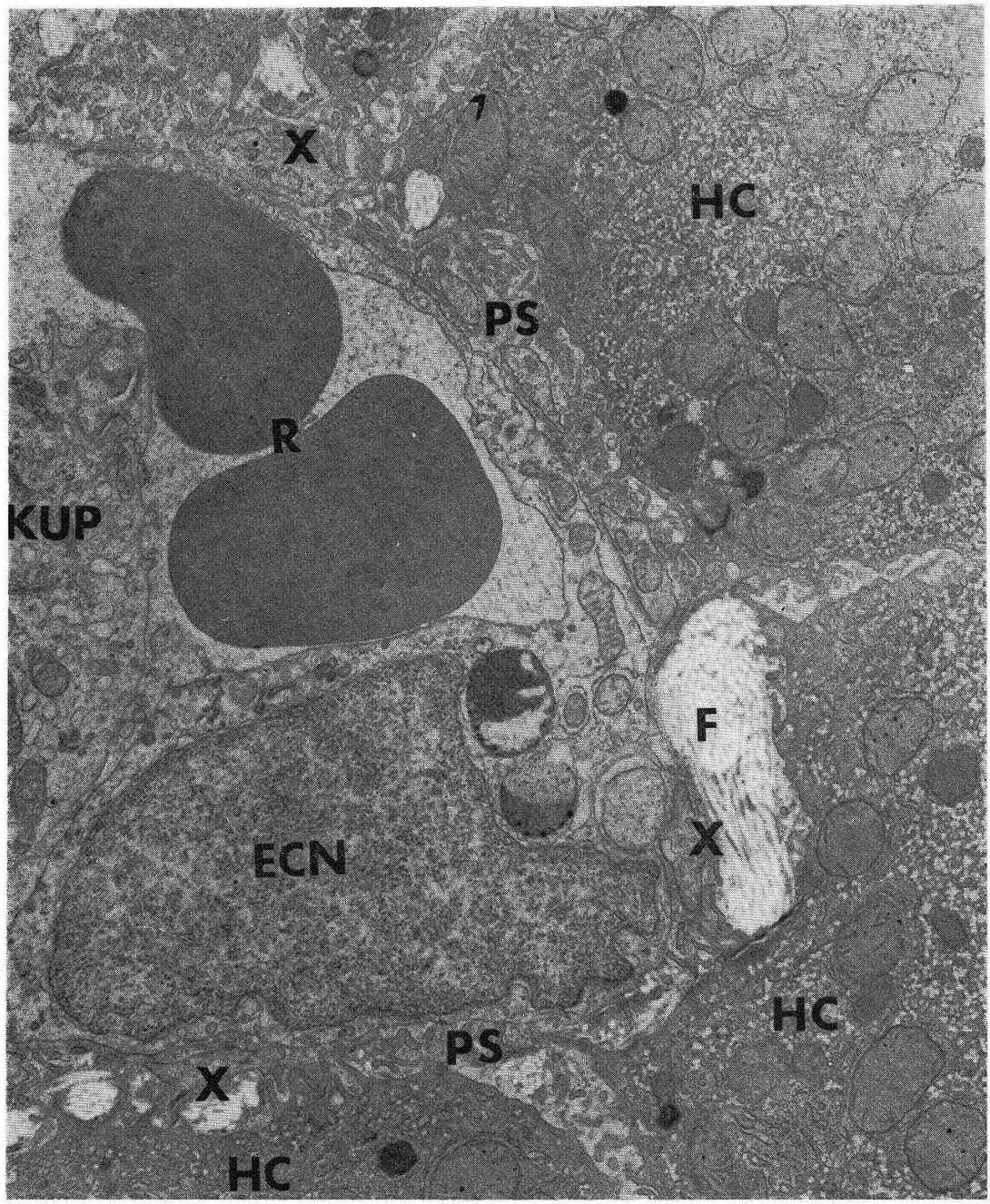

Fig. 6. The perikaryon and the thin cytoplasmic sheet of an endothelial lining cell, on the left side of the perikaryon a cytoplasmic portion of a Kupffer cell $(K U P)$ is also seen. In the perikaryon, on one side of the nucleus ( $E C N)$ large vacuoles containing granular material (phagosomes) and small mitochondria and granular endoplasmic reticulum which are distributed also in the cytoplasmic shect. The perisinusoidal space $(P S)$ contains collagen fibers $(F)$ and fibrils, cross sections of the latter appear as clear dots among microvilli. $H C$ hepatocytes, $R$ erythrocytes, $X$ subendothelial processes of the fat-storing cells. $\times 6,900$ 
in variable frequency, among which coated ones are also observed (Fig. 1, 4, 5, 6). Besides the above mentioned pinocytotic vesicles there occur in almost all endothelial cells some large vacuoles bounded by a smooth limiting membrane. They are accumulated frequently in the paranuclear region but may occur also in supranuclear zone (Fig. 4, 5, 6). They contain finely particulated material of variable electron density, but almost empty ones may sometimes be encountered. These vacuoles probably represent so-called phagosomes and suggest the phagocytic activity of the endothelial cells. In the endothelial lining cells of the human hepatic sinusoids observed in the present study the frequency of the occurrence of the phagasomes seems to be fairly high, this evidence may probably indicate the vigorous phagocytic activity of the endothelial lining cells of the human hepatic sinusoids.

The free surface of the perikaryon of the endothelial cells facing the sinusoidal lumen shows more or less a tortuous contour, but, contrary to that of the Kupfer cells, it does not usually protrude slender cytoplasmic projections except occasional ones as found in Figures 5 and 6 . The endothelial cell illustrated in Figure 5, extends a thin cytoplasmic process around an erythrocyte adhering to the surface of it suggesting the occurrence of the erythrophagocytosis. The opposite side of the cell bordering the perisinusoidal space is almost even without sending any projection into the latter.

The marginal portion of the perikaryon of the endothelial cells is reduced in thickness and spreads out as a thin cytoplasmic sheet surrounding the sinusoid. The endothelial cytoplasmic sheet varies in thickness from place to place $(30-450 \mathrm{~m} \mu$ in width) and occupies the major part of the endothelial lining of the sinusoid. It possesses two free surfaces bordering the sinusoidal lumen and the perisinusoidal space, both of which take a somewhat tortuous course; they are lacking in cytoplasmic processes. The pinocytotic vesicles and invaginations of variable sizes are not so numerous as in the endothelial lining of other capillaries (Fig. 1, 2, 3, 6). The small cisternae of the granular endoplasmic reticulum and clusters of the free ribosomes are visible here and there in small number, though the mitochondria are almost completely absent. Between the marginal parts of these thin cytoplasmic extensions of neighboring endothelial cells the cell connections are seen (Fig. 2), in which the free edges of the adjacent endothelial sheets overlap like the tiles on the roof; a minute slit about $200 \AA$ in width is maintained between the in parallel apposed plasma membranes. However, a distinct cell junction like a terminal bar and desmosome is never recognized there.

The endothelial sheets or lamellae lining the human hepatic sinusoids are discontinuous; several pores or gaps of variable width $\left(40-350 \mathrm{~m}_{\ell}\right)$ are observed here and there at irregular intervals (Fig. 1, 2, 3, 15). These endothelial interruptions seem to be no artifacts and to be intracellular, but are never intercellular in nature, since under physiological conditions the overlapped edges of the neighboring endothelial sheets might not be easily detached making more or less wide intercellular gaps, if such changes should not utterly be impossible. Nevertheless, it may be conceivable that the blood plasm might be able to flow out through these endothelial pores from the sinusoid into the perisinusoidal space and vice versa.

It has been proposed by several authors that the thin endothelial lining of the hepatic sinusoid is here and there stratified into two or more layers. In the present 
study the pictures which may suggest the occurrence of the stratified endothelial sheets lining the human hepatic sinusoid were often encountered (Fig. 1, 2, 3, 6). But as will be later described in detail, it has been proved, that the cytoplasmic lamellae or pieces of different shapes and sizes closely apposed on the outer surface of the endothelial sheet are for the most part nothing but the cytoplasmic extensions of the fat-storing cells present in the perisinusoidal space. Their cytoplasmic matrix appears somewhat denser than that of the endothelial lining cells. So we are now of opinion that the endothelial lining of the human hepatic sinusoids should be as a rule simple being probably reinforced by slender cytoplasmic projections of the fatstoring cells.

The concept, that the endothelial lining of the hepatic sinusoids is commonly devoid of the basement membrane, may fit the majority of mammalian livers described hitherto. This is also the same with the human liver; in the present study we actually could not identify a distinct and continuous basement membrane beneath the endothelial lining of the sinusoids of the normal human liver. In the perisinusoidal space there exists between interlacing microvilli protruded from the hepatocytes an amorphous or cloudy material of fairly high electron density, which occasionally shows tendency to form, just beneath the endothelial lining, membranous structures continuous only for short distances (Fig. 3, 6, 15, 16); they do not, however, make an extended membrane corresponding to the basement membrane.

Kupffer cells. These rounded cells are voluminously projected from the sinusoidal wall into the lumen. In several morphological aspects they resemble the perikaryon of the sinusoidal lining cells, but there exist some ultrastructural differences: They are in general more cytoplasm-rich and larger than the perikaryon of the endothelial cells ; their free surface facing the sinusoidal lumen is, contrary to that of the latter, highly uneven and irregular, sending out numerous microvillus-like projections in different directions (Fig. 3, 6, 7), which presumably correspond to the pseudopods. A part of the free surface may border directly on the perisinusoidal space like the perisinusoidal surface of the perikaryon of the endothelial cell. From this surface a few short microvillous processes are occasionally projected into the perisinusoidal space (Fig. 3, 7, 13). In the Disse's space, just beneath and parallel with the Kupffer cells, there may often occur more or less short cytoplasmic sheets similar to those of the endothelial cells (Fig. 3, 7), which, however, may probably be cytoplasmic processes of the fat-storing cells or microvilli of the hepatocytes.

It seems difficult to answer the question whether or not the Kupffer cells extend, like the endothelial lining cells, thin lamellar cytoplasmic projections bordering the perisinusoidal space, since they are too large to be detected all around their entire cell boundaries by electron microscopy. However, it seems to be likely, that they are rounded-up cells without any lamellar cytoplasmic extensions lining the sinusoid, except for the slender microvillous projections as mentioned above. The following connections between the Kupffer cell and the endothelial cell have been observed: the finger-shaped end part of the cytoplasmic sheet of the endothelial cell lining the sinusoid comes in contact with the marginal portion of the perisinusoidal surface of the Kupffer cell. At the contact place, a minute slit about $250 \AA$ in width is recognized between the juxtaposed plasma membranes of both cell types; a distinct terminal bar has not been identified (Fig. 3, 8, 9). 


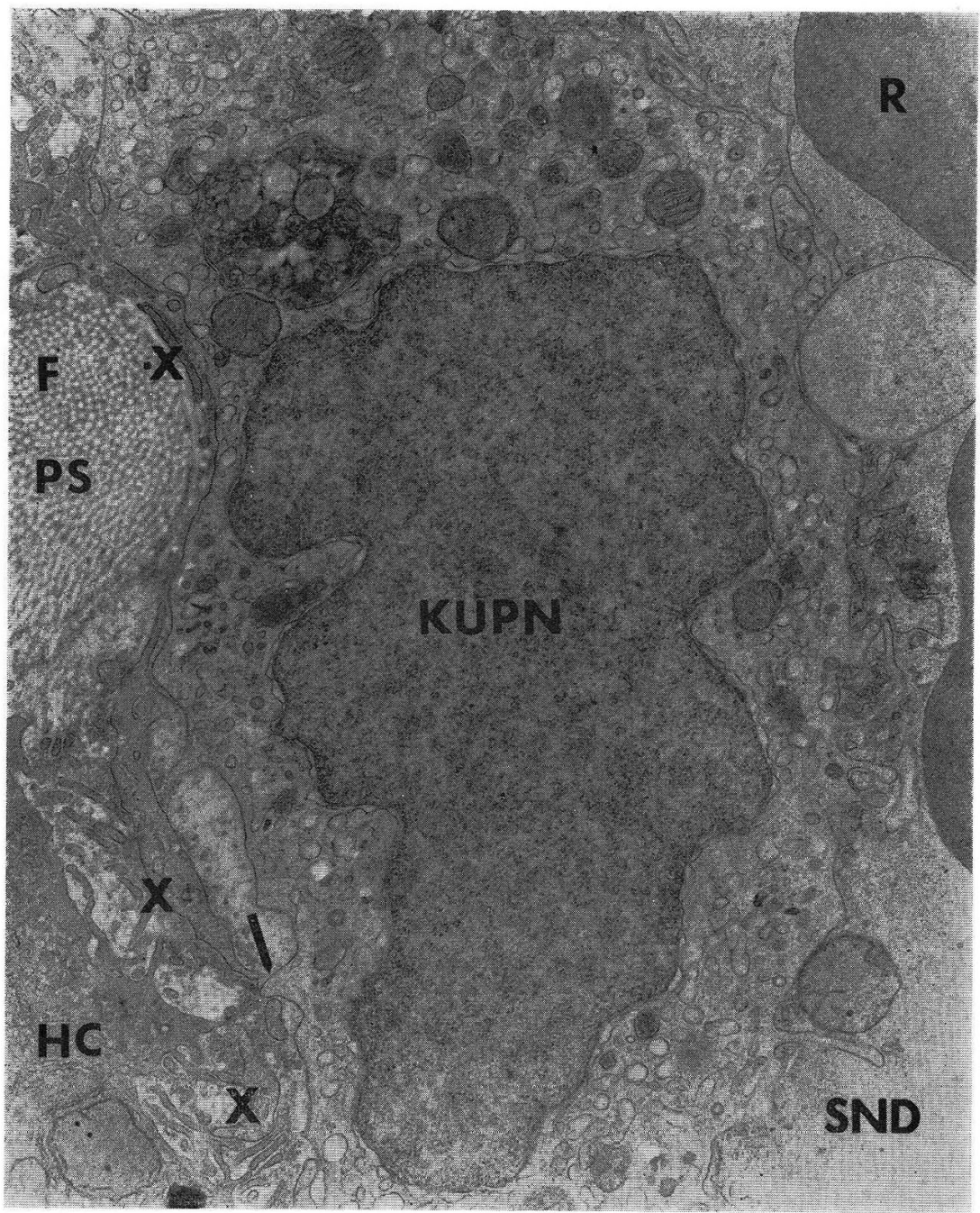

Fig. 7. A Kupffer cell bounding the perisinusoidal space $(P S)$ in which it sends out a few cytoplasmic processes (arrow). In the voluminous cytoplasm there are observed a large irregularly shaped nucleus $(K U P N)$, many smooth vesicles or vacuoles, several mitochondria and large phagosomes or lysosomes. The sinusoidal surface protrudes numerous irregular cytoplasmic processes (pseudopods) into the sinusoidal lumen $(S N D)$. In the perisinusoidal space $(P S)$ collagen fibers of variable thickness $(F$, unstained) and fibrils seen as clear dots among hepatocytic microvilli and just beneath the Kupffer cell a hepatocytic microvillus (upper $X$ ) and subendothelial processes (lower $X$ ) of the fat-storing cell are seen. $H G$ hepatocyte, $R$ erythrocyte in sinusoid.

$$
\times 11,000
$$

The nucleus of the Kupffer cells is not by far different from that of the endothelial cells, its location in the ccll body is variable. The ultrastructure of the cytoplasm is much more complex as compared with that of the endothelial cells. Especially the well-developed Golgi complex is prominent, which occupies a large 


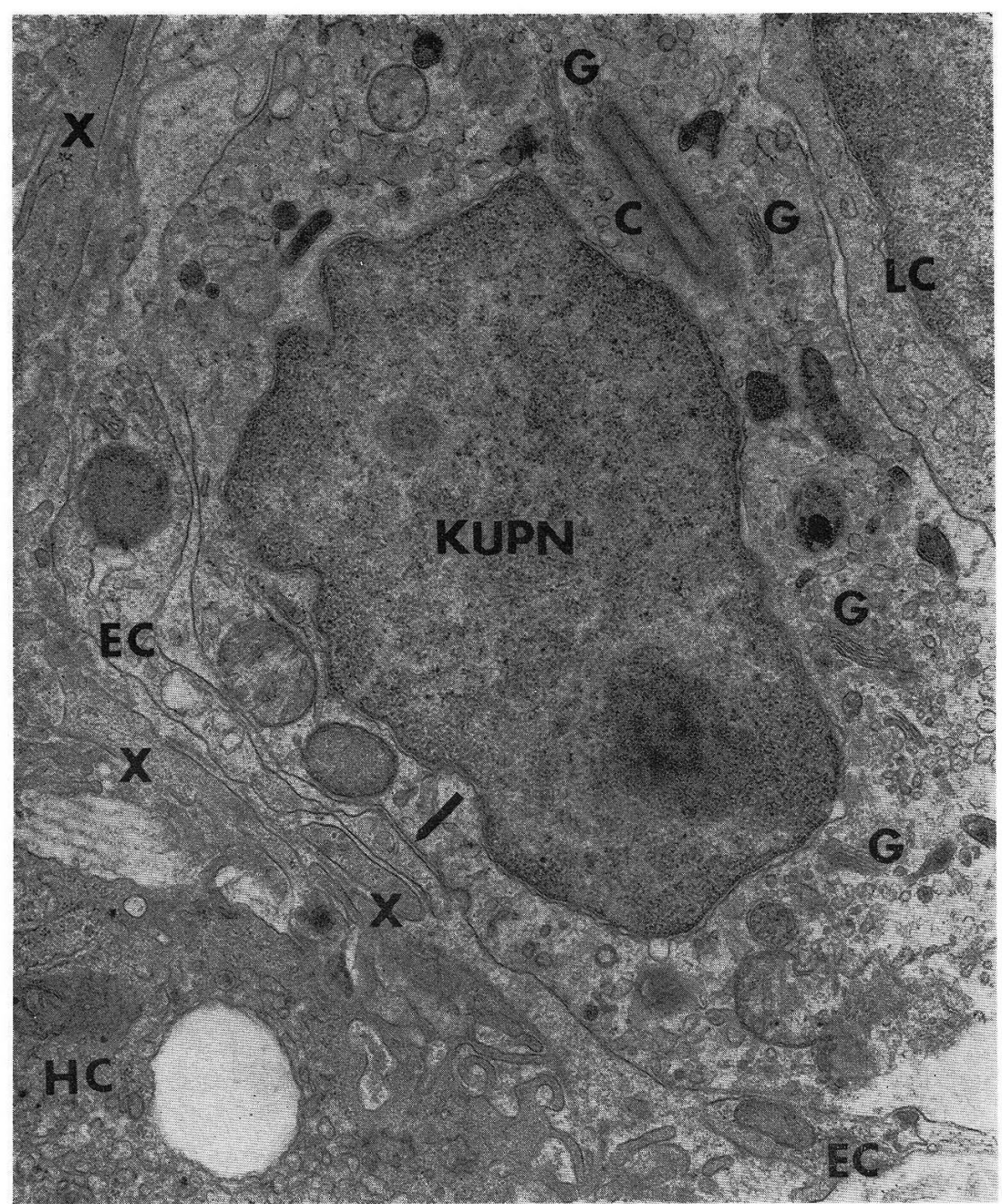

Fig. 8. A Kupffer cell projected extensively into the sinusoidal lumen. An irregularly shaped nucleus (KUPN) contains a nucleolus (lower right) and a nuclear body (sphaeridion) (upper left). In the cytoplasm, there are observed Golgi complex $(G)$, an extraordinarily long centriole $(C)$ located within the Golgi area, several mitochondria, numerous smooth membraned vesicles and dense bodies. The edge of the endothelial sheet $(E C)$ comes into connection with the perisinusoidal surface of the Kupffer cell (arrow). Subjacent to the endothelial sheet $(E C)$ there occur in the perisinusoidal space several subcndothelial processes $(X)$ of the fat-storing cell. $H C$ hepatocyte, $L C$ lymphocyte in sinusoidal lumen. $\times 15,000$

area near the nucleus (Fig. 3). The Golgi complex consists of mainly lamellae and vesicles; the Golgi vacuoles are rare. The mitochondria are spherical or rod-shaped and somewhat larger and more numerous than those of the endothelial cells (Fig. 3, $6,7)$; they are, however, smaller than those of the hepatocytes. The centriole was only rarely demonstrated ; in a Kupffer cell illustrated in Figure 8, an extraordi- 
narily long centriole cut longitudinally is seen, which measures $1.25 \mu$ in length and $0.23 \mu$ in width and shows an intimate topographical relationship with the Golgi complex. Further, the Kupffer cells possess a well-developed agranular endoplasmic reticulum which spreads out throughout the entire cytoplasmic areas (Fig. 7). It consists of numerous cisternae and vesicles of various shapes and sizes bounded by a smooth limiting membrane. The contents of the cisternae and vesicles are generally electron lucent. Along the plasma membrane lining the free sinusoidal surface pinocytotic invaginations and vesicles are observed; further there occur vacuoles embraced by the slender microvillous cytoplasmic processes corresponding to pseudopods (Fig. 3, 6, 7), which occasionally contain electron dense particles and finely granular materials. The well-developed agranular endoplasmic reticulum seems to

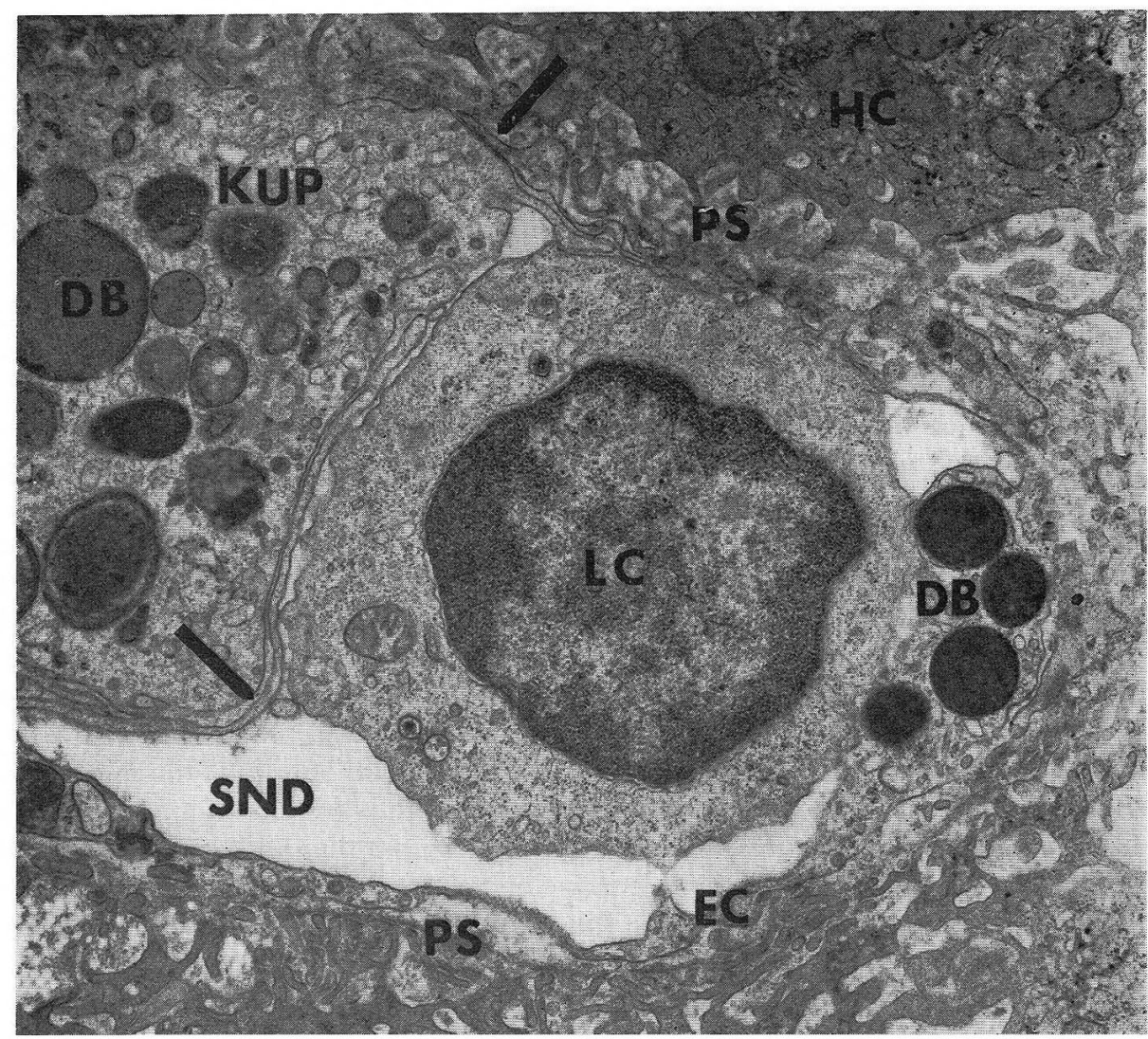

Fig. 9. A Kupffer cell $(K U P)$, a lymphocyte $(L C)$ and endothelial cell sheet $(E C)$ lining the sinusoid $(S N D)$. The Kupffer cell contains numerous spherical dense bodies $(D B)$ (lysosomes) of variable size and abundant smooth vesicles. Similar spherical dense bodies $(D B)$ are also observed in a cytoplasm-rich portion of the endothelial sheet $(E C)$. Long, slender cytoplasmic processes (pseudopods) $(\downarrow)$ arc protruded from the Kupffer cell. The upper free surface of the Kupffer cell bounds the perisinusoidal space $(P S)$ and comes into connection at the right margin with the edge of the endothelial sheet (arrow). In the perisinusoidal space there occur among hepatocytic microvilli numerous cross sections of collagen fibrils seen as clear dots. 
be related to this active movement of the surface plasma membrane. The elements of granular endoplasmic reticulum and free ribosomes are very rare, they are in general less numerous than in the endothelial cells (Fig. 8). In the cytoplasm of the Kupffer cells found in the hepatic sinusoid of the normal human liver examined in the present study, large phagocytic vacuoles containing dense materials as observed in the endothelial cells were scarce, though membrane bound dense bodies of various shapes and sizes were usually found in variable numbers (Fig. 3, 7, 8, 9) which may be considered as phagosomes or lysosomes. The Kupffer cells seen in Figures 3, 6, 7 and 8 contain relatively small numbers of dense bodies, whereas the cell found on the left side of Figure 9 contains numerous spherical dense bodies of high electron density. This Kupffer cell possesses an extraordinarily long cytoplasmic projection extended along the cell boundary facing on the adjacent lymphocyte. Further, another short process is protruded toward the upper left corner of the lymphocyte. On the right side of the lymphocyte the perikaryon of an endothelial cell is seen, from the upper and bottom margin of which sheet-like cytoplasmic extensions spread out lining the sinusoid. The perikaryon of this endothelial cell contains four large spherical dense bodies of high electron density identical with those found in the above mentioned Kupffer cell indicating the cytological similarity between the Kupffer cell and the endothelial lining cell.

Microvilli in the hepatocytes. As has been first demonstrated by FAwcett (1955) innumerable slender microvilli protruding from the hepatocytes penetrate the perisinusoidal space and recessus ; their population density in both spaces is in general fairly high. In the portion where the perisinusoidal space contains a thick bundle of the collagen or reticular fibrils, however, the microvilli are decreased in number and in length and occasionally disappear almost completely (Fig. 1-9). The microvilli are bounded by the plasma membrane continuous with that lining the free surfaces of the hepatocytes facing the perisinusoidal space and recessus, their homogeneous cytoplasmic matrix is as electron dense as that of the hepatocytes and contains neither organelles nor inclusion bodies. Their thickness is generally uniform from the root to the tip $(0.1 \mu)$, but they may frequently be more or less thickened in their basal portion continuous with the cell body. Simple ramifications of the microvilli are not rare. It is difficult to measure the actual length of the microvilli, since they are irregularly curved in the Disse's space; they frequently interlace with each other, and some of them are even oriented in parallel with the endothelial lining of the sinusoid. Among these interlacing microvilli the Disse's space makes a complicated labyrinth containing amorphous or cloudy dense material similar to the blood plasm in the sinusoid and reticular fibrils. In the location where the fatstoring cells, as will be described later, occur in the Disse's space, the hepatocytic microvilli are closely related to them being distributed also in the space between the fat-storing cells and the adjacent hepatocytes. However, in the narrow space between the fat-storing cells and endothelial lining cells of the sinusoid no microvilli are distributed except for a few reticular fibrils and the amorphous or cloudy dense materials just mentioned above. The microvilli adhere neither to the endothelial lining of the sinusoid nor to the fat-storing cells including their cytoplasmic processes.

Reticular fibers. The fibrillar components which may represent what had been 
described by light microscopy as reticular or lattice fibers (Gitter- or Retikulumfaser), have been observed by electron microscopy in the perisinusoidal space and described by many workers as collagen or reticular fibers. They are bundles of fibrils, but single fibrils can also occur. By the present electron microscopic study, it has been confirmed that in the perisinusoidal spaces of the normal human liver there occurs a considerable amount of the collagen fibers of different thickness which are composed of closely packed fibrils and oriented in various directions. We could not satisfactorily stain these fibers; they generally appeared electron transparent (Fig. $3,5,6,7$, etc.). Among these closely packed, electron lucent reticular fibrils, amorphous or minutely fibrillar material with a moderate electron density is seen. Besides these compact fibers of different thickness, there occur in the Disse's space numerous collagen fibrils singly or in small groups. They are scattered among the hepatocytic microvilli, and, when they are embedded within the dense homogeneous or cloudy material of the space, the cross sections of them appear as conspicuous electron lucent dots. These single fibrils are distributed up to just beneath the endothelial lining of the sinusoids, so the distribution of electron lucent dots can point out the innermost boundary of the perisinusoidal space. In the recesses between the adjacent hepatocytes, no collagen fibers and fibrils were identified. The amount and thickness of the collagen fibers in Disse's space gradually increase toward the periphery of the hepatic lobules, namely toward the portal tracts or the interlobular connective tissue.

The thickness of fibrils is variable ranging from $300 \AA$ to $700 \AA$ in diameter (in average about $500 \AA$ ). Occasional fibrils, in which the staining has gone well, exhibit cross striations along their long axis spaced at intervals of approximately $640 \AA$.

Fat-storing cells. In the perisinusoidal space of the normal human livers there occur frequently just beneath the endothelial lining of the sinusoid the "fat-storing. cells" which are in comparison with the hepatocytes small and electron lucent and characterized by various number of small fat droplets contained in the cytoplasm. In the sections prepared for the present study the blackening by osmic acid of the fat droplets contained in fat-storing cells was poor or they were completely dissolved during the procedures of embedding, so they appeared in the electron micrographs either as vacuoles with electron lucent homogeneous content or quite empty. The fat-storing cells are separated from the sinusoid always by the endothelial cells and never exposed directly to the sinusoidal lumen. They are all around surrounded by the perisinusoidal space (Fig. 10). Between the endothelial cell and the sinusoidal surface of the fat-storing cell the perisinusoidal space is narrowest containing dense cloudy or homogeneous material and small amount of collagen fibrils scattered singly or in small groups. In this subendothelial portion of the Disse's space, as described below, slender extensions of the fat-storing cells are distended parallel with the endothelial lining. The evidence, that in this space the continuous basement membrane of the endothelial cells cannot be identified, has been already reported. Other portions of the Disse's space limited by the fat-storing cell and the hepatocytes are of variable width and contain hepatocytic microvilli and collagen fibers of variable thickness as well as fibrils scattered singly or in small groups among the microvilli. On the basis of the above mentioned findings it has been elucidated that the fat- 


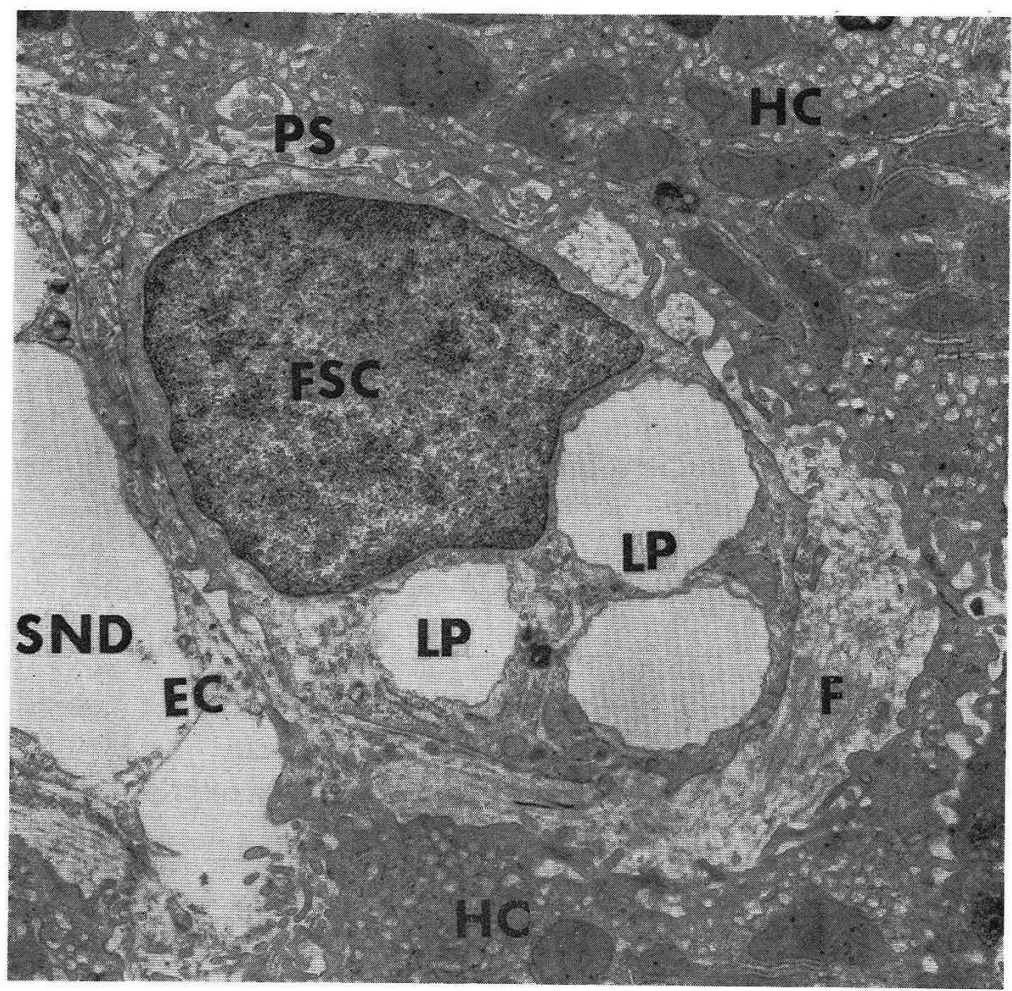

Fig. 10. A fat-soring cell $(F S C)$ in the perisinusoidal space (PS). The fairly round cell body is all around surrounded by the perisinusoidal space containing collagen fibers $(F)$ and microvilli of the hepatocytes $(H C)$ and separated from the sinusoid $(S N D)$ by the cytoplasmic sheet of the endothelial lining cell $(E C)$. From the surface of the fat-storing cell, some microvillous projections are protruded into the pcrisinusoidal space. On one side of the nucleus three fat droplets $(L P)$ are visible, in the cytoplasm besides fat droplets small mitochondria and elements of granular endoplasmic reticulum are seen. $\times 7,400$

storing cells located in the perisinusoidal space are covered all around by the collagen fibers or fibrils, but along the surface of the fat-storing cells facing the subendothelial space there occur in general only a small number of fibrils scattered singly or in small groups. This electron microscopic findings agree with the light microscopic results obtained by observing the preparations stained by silver impregnation (Ito, Satsuki and Tahira 1953). Though the apposing surfaces of the fat-storing cell and the hepatocyte are generally by far separated by microvilli and collagen fibers contained in the Disse's space, a close contact of them has been occasionally demonstrated in the present study. As seen in Figure 19, the even surfaces both of the hepatocyte and the fat-storing cell are closely adjoined in parallel lines and the two closely apposed plasma membrancs lining the both surfaces are separated by a narrow cleft about $200 \AA$ in width. These structures may probably be responsible for the intimate functional connection between the fat-storing cell and the hepatocyte. 
The fat-storing cells are situated in the Disse's space, but extend frequently for some extent into the recessus between adjacent hepatocytes. Sometimes they are found in a depression on the sinusoidal surface of a hepatocyte, by which the perisinusoidal space is locally widened.

The shape of the fat-storing cells is manifold; they seem to be more or less elongated cells extended along the sinusoid, thus in longitudinal sections they show spindle-shapes containing an elongated or oval nucleus (Fig. 11, 12, 13, 15, 18, 21), in cross sections they appear as rounded cells containing a round nucleus (Fig. 10, 14). They send out, contrary to the endothelial cells, from the surfaces facing on the adjacent hepatocytes several slender microvillous projections which interlace with the hepatocytic microvilli and appear commonly more electron lucent than

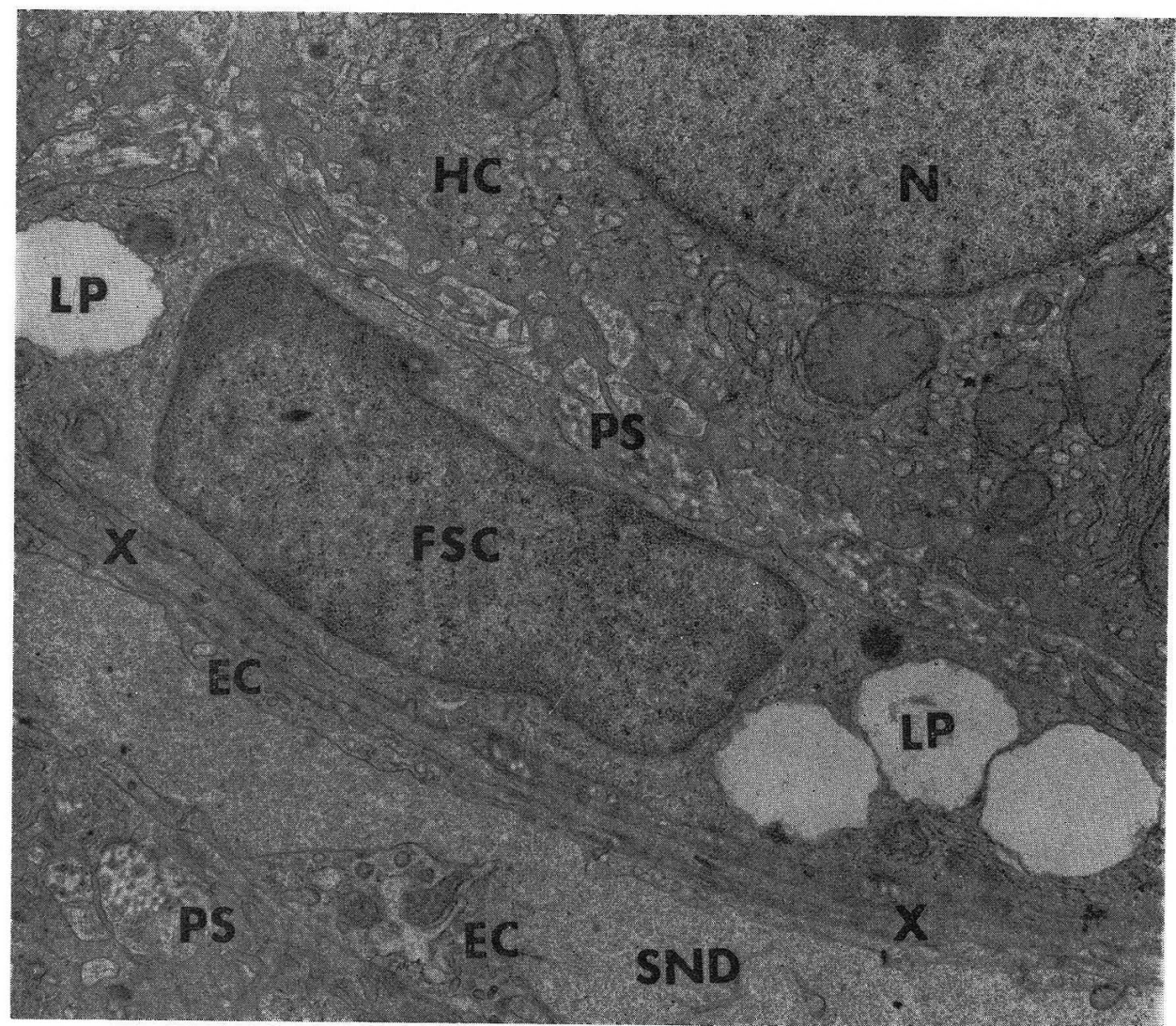

Fig. 11. A longitudinal section of a fat-storing cell (FSC) elongated along the sinusoid (SND), which is interposed between two endothelial sheets $(E C)$. It is located in the perisinusoidal space $(P S)$ and completely separated from the sinusoid by the endothelial sheet $(E C)$. It contains an elongated nucleus, four fat droplets $(L P)$, a few small mitochondria, elements of the granular endoplasmic reticulum and small dense body. Between the endothelial sheet and the fat-storing cell a long, slender subendothelial process of the fat-storing cell is observed elongated in parallel and closely apposed to the endothelial sheet. Collagen fibrils are seen as clear dots in the perisinusoidal space on both sides of the fat-storing cell. $H C$ hepatocytc, $N$ nucleus of the hepatocyte. 


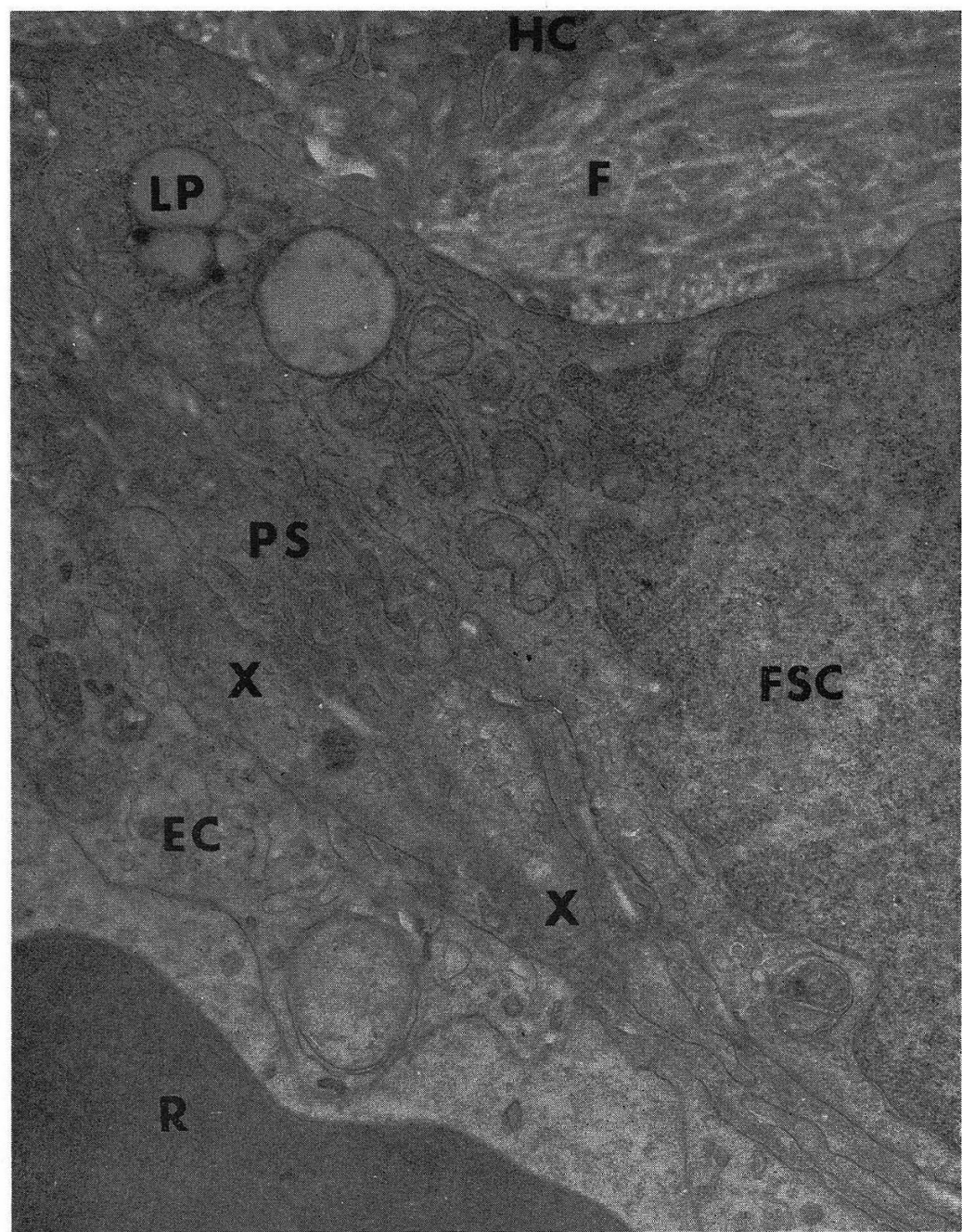

Fig. 12. A part of a fat-storing cell $(F S C)$ elongated along the sinusoidal wall. It is located in the perisinusoidal space $(P S)$ being separated from the sinusoid by the endothelial sheet $(E C)$ lining the sinusoid. Between the endothelial sheet and the fat-storing cell subendothelial processes $(X)$ of the fat-storing cell are interposed. On one side of the nucleus an accumulation of mitochondria and associated ergastoplasmic sacs are present. In the upper left end of the cytoplasm small, probably immature fat droplets of somewhat high electron density are seen. The wide perisinusoidal space above the fat-storing cell is occupied by a large bundle of collagen fibrils $(F)$ and in narrow perisinusoidal space subjacent to the endothelial sheet a number of collagen fibrils (clear) are detectable. $H C$ hepatocyte, $R$ erythrocyte in sinusoid. $\times 26,400$

the latter (Fig. 10, 13, 14). Further, it must be a very important finding, that the fat-storing cells protrude from the surface facing the endothelial cells several cytoplasmic projections into the subendothelial space which run almost parallel with the latter (subendothelial projections of the fat-storing cell), among them the long slender 


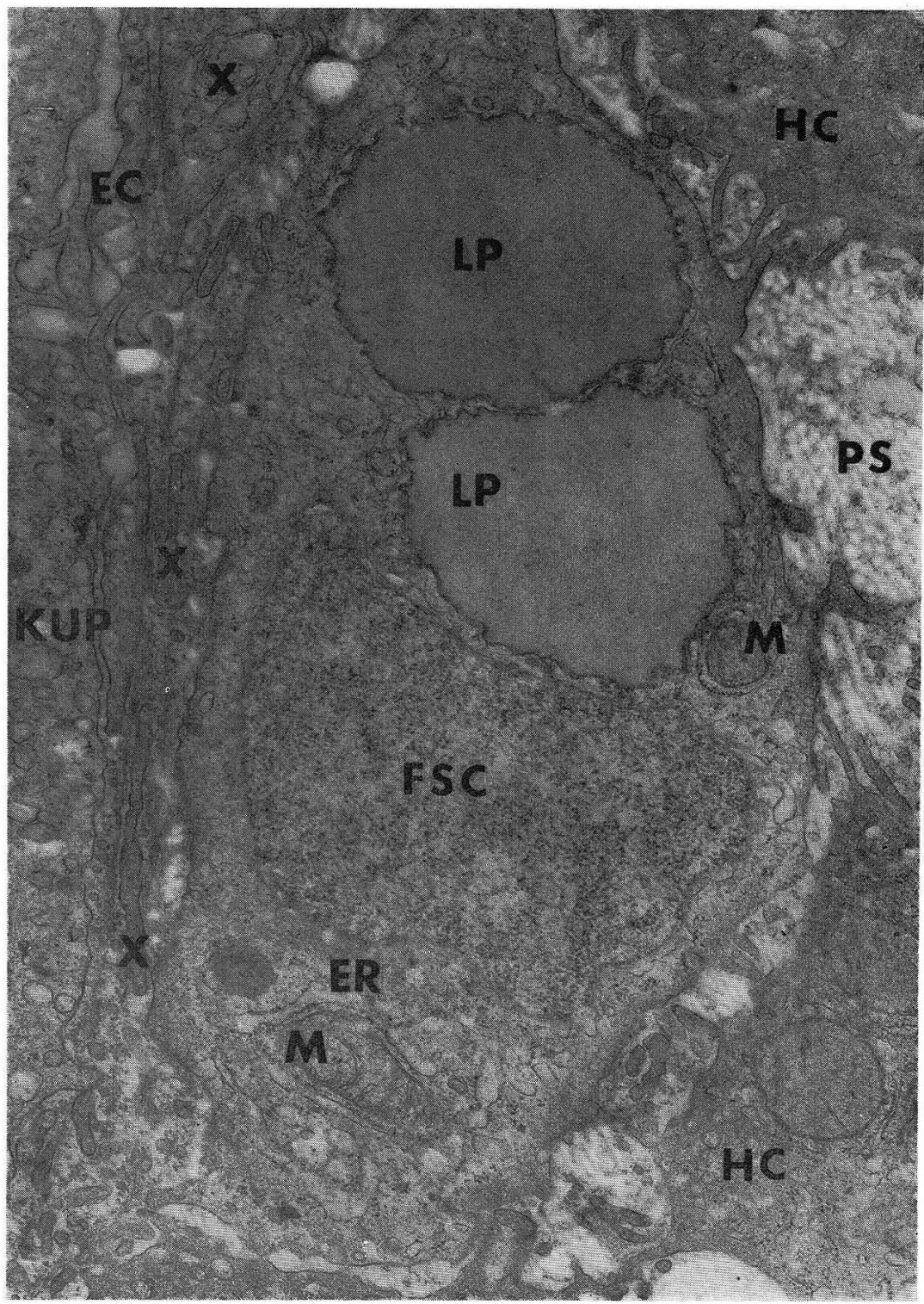

Fig. 13. A fat-storing cell $(F S C)$ containing two somewhat well-preserved fat droplets $(L P)$. The nucleus shows a slight depression induced by the fat droplet. In the cytoplasm, a few mitochondria $(M)$ numerous ergastoplasmic sacs $(E R)$ partly associated with mitochondria and free ribosomes are seen. From the perisinusoidal surface, several microvillous projections are protruded and especially subendothelial process $(X)$ of variable thickness are seen in the narrow perisinusoidal space containing a few collagen fibrils (clear) between the fat-storing cell and the Kupffer cell $(K U P)$. From the perisinusoidal surface of the Kupffer cell a small process is protruded into the Disse's space. EC endothelial sheet, $H C$ hepatocytes, $P S$ perisinusoidal space containing collagen fibers and fibrils (clcar). $\times 24,500$ 


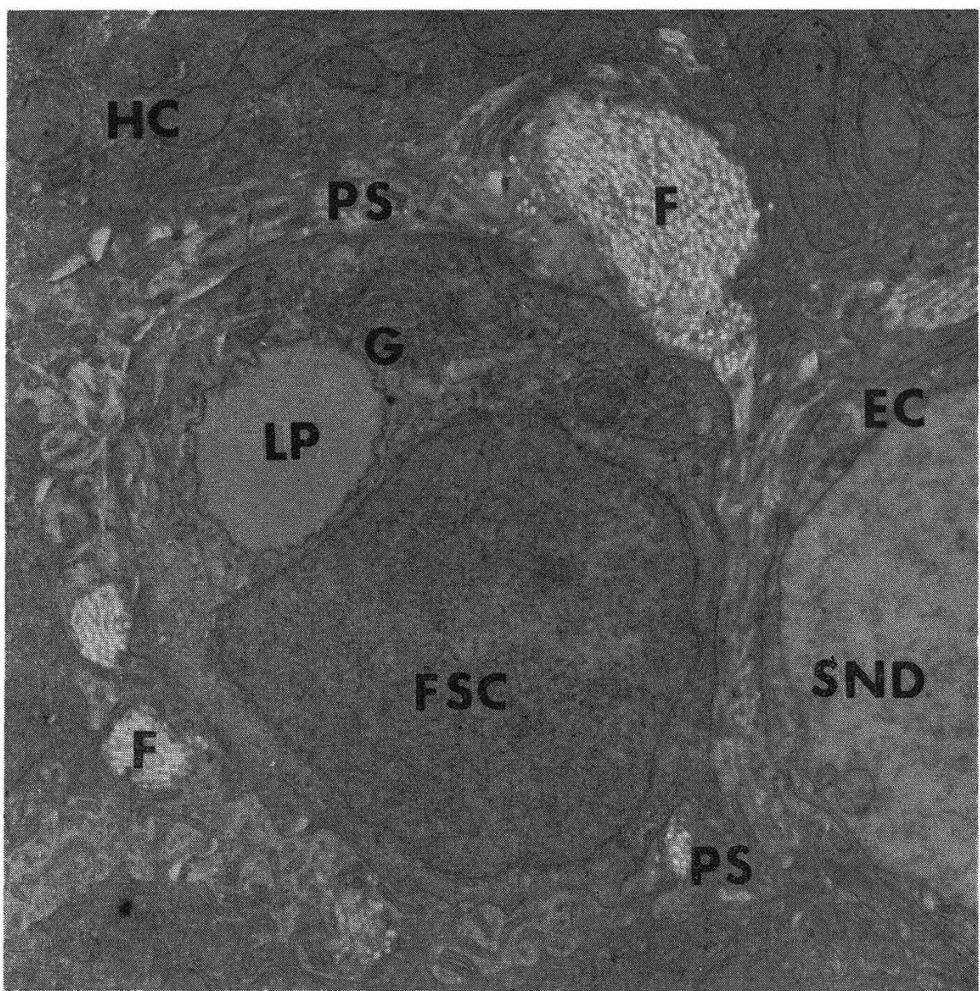

Fig. 14. A transverse section of a fat-storing cell $(F S G)$ separated from the sinusoid $(S N D)$ by the endothelial sheet $(E C)$. Above the nucleus, the Golgi complex $(G)$, a fat droplet $(L P)$ and other cell organelles are seen. Collagen fibers $(F)$ of variable thickness are observed in the perisinusoidal space $(P S)$ around the fat-storing cell. $H C$ hepatocytes. $\times 8,500$

projections running beneath the endothelial sheet are often confused with the overlapping endothelial lining, they show sometimes pinocytotic invaginations and vesicles, but their cytoplasmic matrix is somewhat more electron dense than that of the endothelial sheet (Fig. 11, 12, 13, 15, 16, 31). In the cytoplasm-rich thick projections, besides pinocytotic invaginations and vesicles, fat droplets, granular endoplasmic reticulum, free ribosomes and small lysosomes are contained (Fig. 17, 18, 31). Further, in occasional fat-storing cells deep invaginations of the surface plasma membrane are seen which reach with their distended internal end near the nucleus (Fig. 19, 20). It is a noteworthy finding that the collagen fibrils are contained in the deep invaginations and especially in the terminal distension seen in Figure 20 a bundle of fibrils is enclosed and prior to the distension the closely apposed plasma membranes exhibit a structure similar to mesaxon. A small round invagination containing a number of fibrils is observed occasionally on the surface plasma membrane of the fat-storing cells. The similar findings, however, are sometimes observed also on the plasma membrane of the hepatocyte lining the perisinusoidal surface. As shown in Figure 16, collagen fibrils can enter also into the space between the subendothelial projec- 


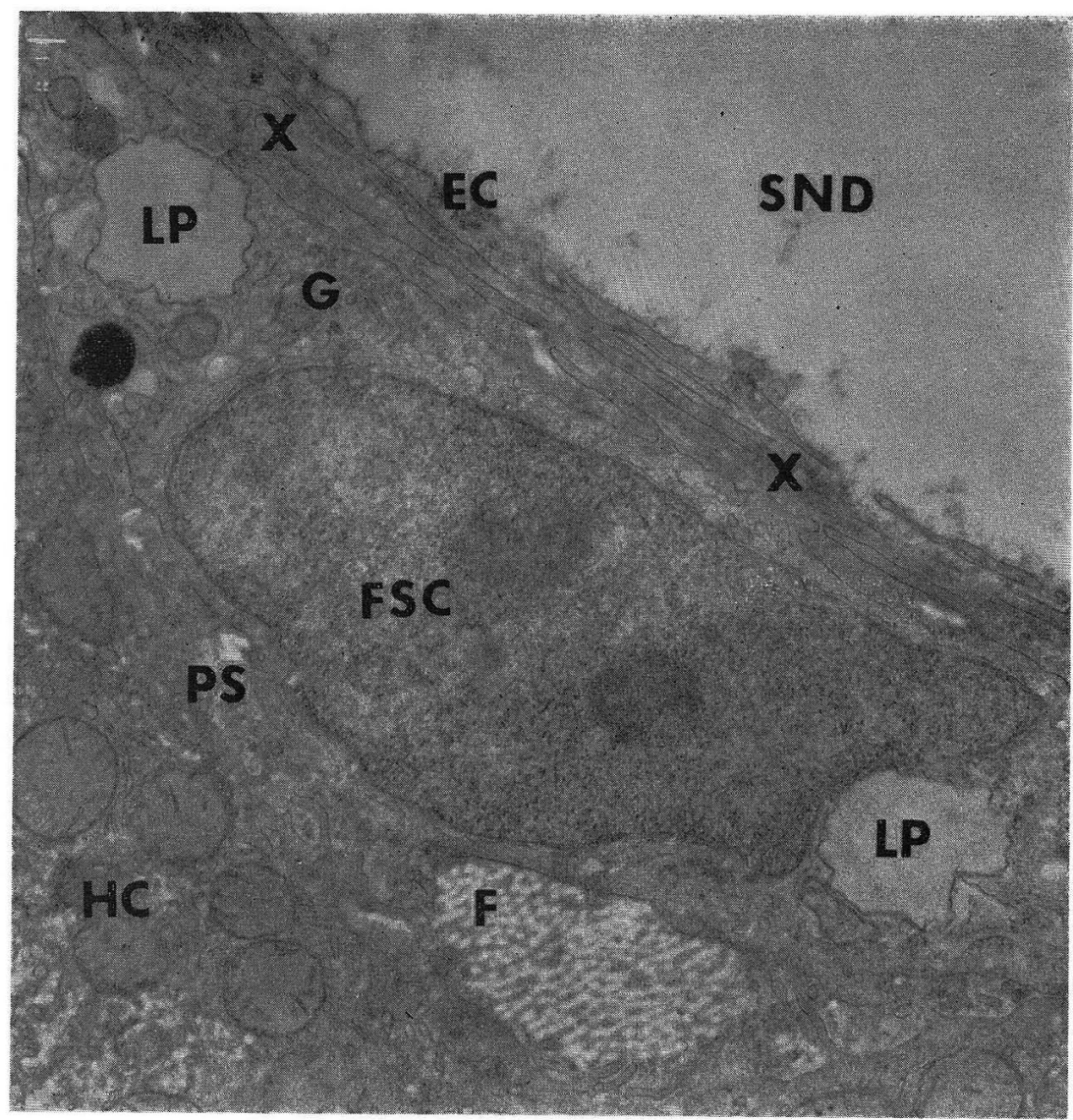

Fig. 15. Several sleader subendothelial processes $(X)$ of a fat-storing cell (FSC) elongated parallel to the endothelial sheet $(E C)$ lining the sinusoid $(S N D)$. In the latter gaps or pores are observed. The elongated nucleus possesses two nucleoli and a sphacridion (nuclear body) between them. In the cytoplasm, Golgi complex $(G)$, a few mitochondria, fat droplets $(L P)$, small dense bodies and pinocytotic vesicles along the surfacc plasma membrane are seen. In the perisinusoidal space $(P S)$ a thick collagen fiber $(F)$ and fibrils (clear) are conspicuous. $H C$ hepatocyte. $\times 14,400$

tion and the cell body of the fat-storing cell. These findings may indicate the close relationship between the fat-storing cell and the reticular fibrils. The basement membrane does not occur around the fat-storing cells, thus, the fibrillar components of the perisinusoidal space come in direct contact with the latter.

The more or less elongated or oval nucleus of the fat-storing cell resembles in general that of the endothelial cell, though it is somewhat larger than the latter. The nuclear envelope show numerous small indentations and nuclear pores and occasionally more or less conspicuous depressions are induced by fat droplets (Fig. $10,13,15,19,22)$. Chromatin material is mainly accumulated along the nuclear envelope making numerous compact aggregations of variable sizes and shapes, which are communicated with the net-like aggregations spread out in the interior of the nucleus. One or two nucleoli are seen in the nucleoplasm, in which the nucleo- 


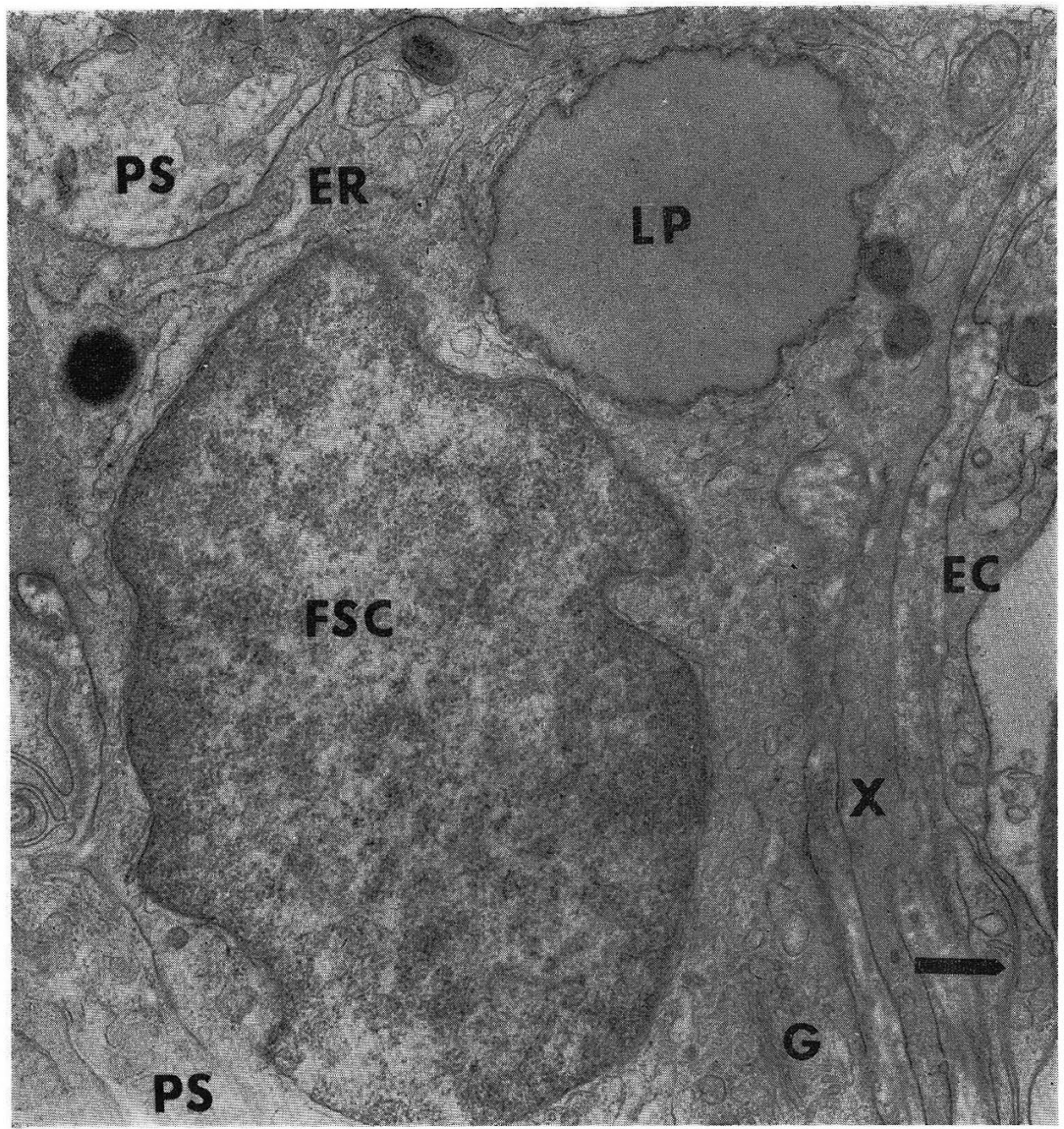

Fig. 16. A slender subendothelial projection $(X)$ protruded from the sinusoidal surface of a fat-storing cell $(F S C)$ which is directed parallel to the endothelial sheet $(E C)$ lining the sinusoid. In the narrow space between the projection and the endothelial sheet a small amount of collagen fibrils (clear) are observed. In the cytoplasm of the fat-storing cell, a fat droplet $(L P)$, a Golgi complex $(G)$, a few mitochondria, many ergastoplasmic sacs $(E R)$, small dense bodies bounded by a distinct smooth limiting membrane and pinocytotic vesicles are seen. In the endothelial sheet an overlapping (arrow) of the edges of the neighboring endothelial cclls is visible. $P S$ perisinusoidal space. $\times 18,500$

lonema is not conspicuous. Besides the nucleolus, there occur not infrequently a few small electron dense "sphaeridies" like those found in the nucleus of the endothelial cclls of the sinusoid (Fig. 15, 18, 19, 21).

The fat-storing cells are by no means cytoplasm-rich cells, so they contain a small number of mitochondria showing rod-shaped, oval and round profiles, the development of the cristae mitochondriales is moderate. They are by far smaller than those of the hepatocytes and as large as those in the endothelial cell; they are scattered randomly in the cytoplasm, but an occasional accumulation is found on one side of the nucleus (Fig. 12). 


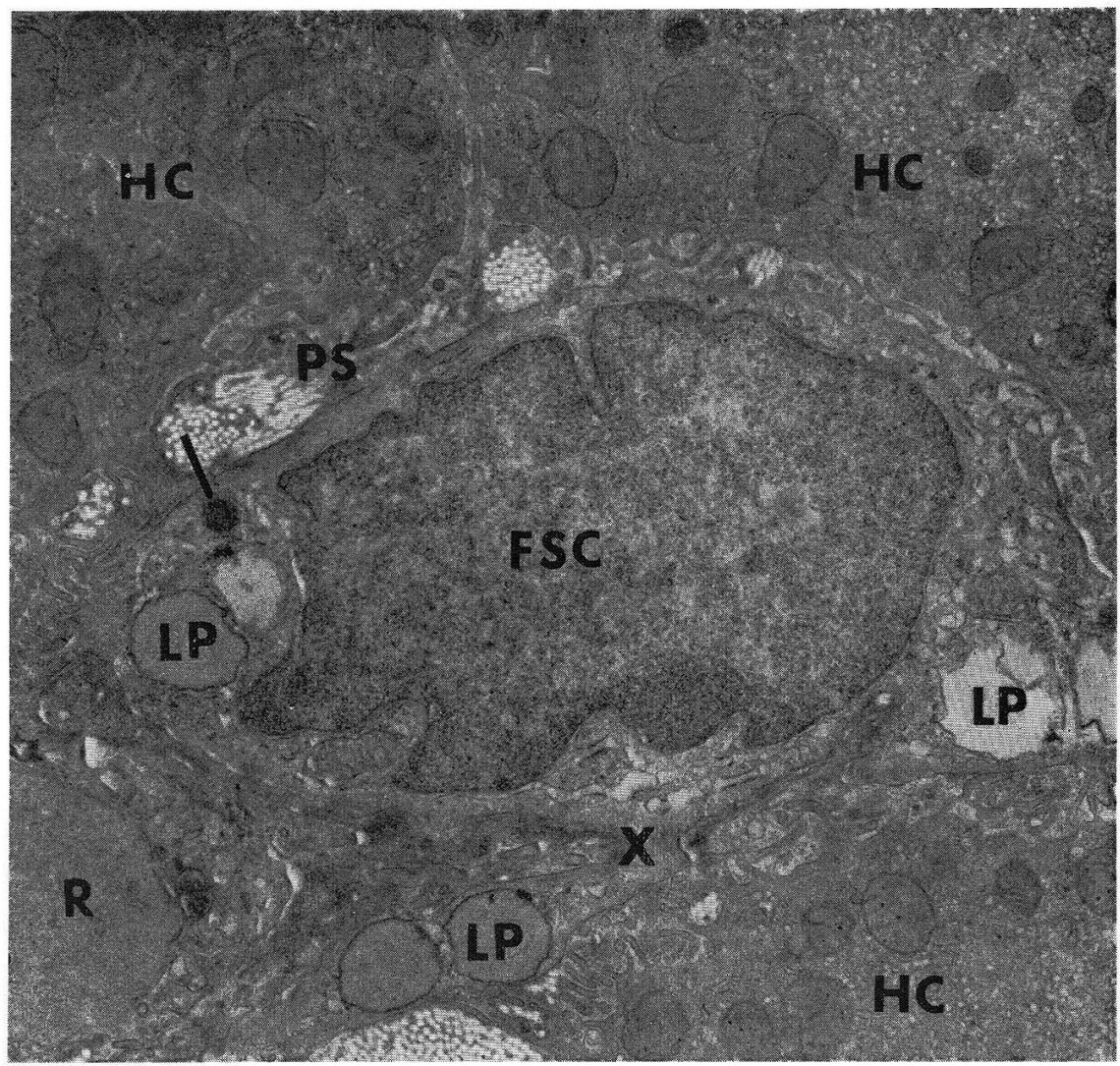

Fig. 17. A thick cytoplasm-rich projection $(X)$ containing two fat droplets $(L P)$ protruded from a fat-storing cell $(F S C)$ into the perisinusoidal space and toward the sinusoid. In the cytoplasm of the fat-storing cell fat droplets $(L P)$, a dense body (arrow) and cell organelles are distributed around the nucleus. $H C$ hepatocytes, $P S$ perisinusoidal space containing microvilli of the hepatocytes and collagen fibers (clear), $R$ erythrocyte in sinusoid. $\times 6,400$

Also near the nucleus the Golgi complex is visible (Fig. 14-16, 19-26) which consist of well-developed Golgi lamellae, numerous Golgi vesicles and some Golgi vacuoles of variable shapes and sizes. The contents of the lamellae and vesicles are for the most part moderately dense, whereas that of the vacuoles is lucent. As clearly recognized in Figures 21 and 22, in the center of the Golgi area there occur a diplosome surrounded by a small area of finely granular, homogeneous cytoplasm devoid of Golgi components. In the cross sections each centriole of the diplosome measures approximately $0.3 \mu$ in diameter, but since the longitudinal sections were not encountered, the length of the centriolar cylinder was not determined. The pattern of the nine peripheral fibers or tubules could not be sufficiently enough discerned (Fig. 19).

In the present study on normal human livers, we could demonstrate in the fatstoring cells the single cilium as well as the diplosome by electron microscopy for the first time, though the latter had been already reported in the light microscopic 


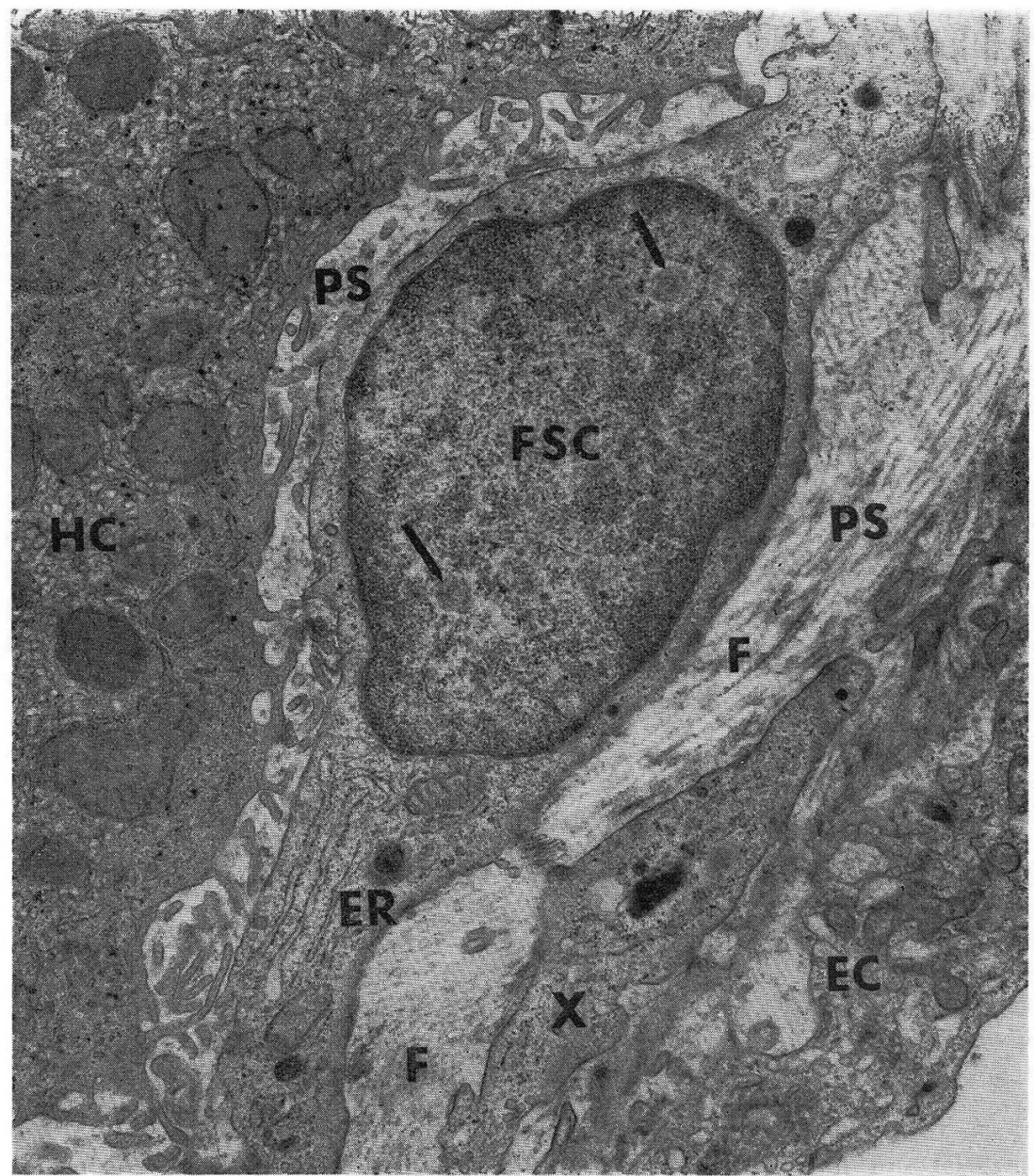

Fig. 18. A spindle-shaped fat-storing cell $(F S C)$ elongated along the sinusoidal wall in which the oval nucleus contains two sphaeridies (arrows). In the cytoplasm there exist a few mitochondria, small dense bodies, the parallel array of flattened sacs of the endoplasmic reticulum $(E R)$, free ribosomes and numerous pinocytotic vesicles along the surface plasma membranc among which somc bristlc-coatcd ones are intermingled. In the perisinusoidal space there occur between the fat-storing cell and the endothelial lining cell $(E C)$ of the sinusoid a thick subendothelial process $(X)$ of the fat-storing cell and large bundle of collagen fibrils $(F)$ and between the fat-storing cell and the hepatocyte $(H C)$ numerous microvilli of the latter. $\times 8,700$

observation carried out by Iто and Neмото (1952). As shown in Figure 23, the single cilium bounded by the plasma membrane is protruded from a basal body into the perisinusoidal space. The longitudinally sectioned basal body measuring about $0.5 \mu$ in length and $0.3 \mu$ in width, exists just beneath the cell surface and within the Golgi area having its long axis at a right angle to the former. The internal ultrastructures both of the cilium and the basal body could not be clarified, since the cross sections of them were missed in the present study. The possibility, that the 


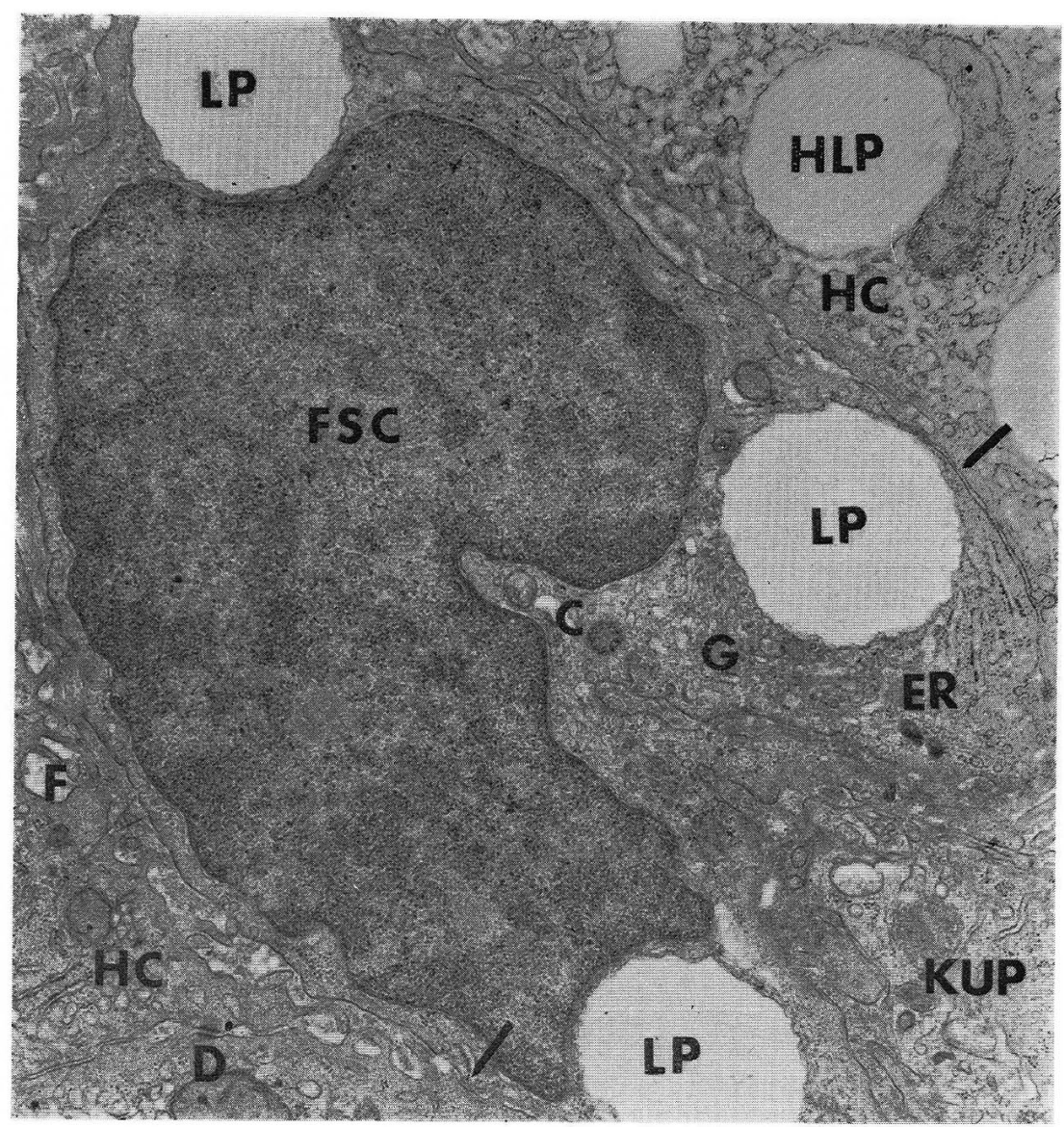

Fig. 19. A fat-storing cell $(F S G)$ in the perisinusoidal space which comes in close contact (arrows) with an adjacent hepatocyte $(H C)$ and shows a deep invagination of the plasma membrane (lower right). In the cytoplasm three fat droplets $(L P)$, Golgi complex $(G)$, transverse section of a centriole, a few mitochondria, granular endoplasmic reticulum $(E R)$ and pinocytotic vesicles along the surface plasma membrane. $D$ desmosome between adjacent hepatocytes, $F$ collagen fiber embraced in a hollow of the hepatocyte, HLP lipid droplet in hepatocyte, KUP Kupffer cell of the sinusoidal wall. $\times 13,200$

basal body might originate from one of the paired centrioles of the diplosome located within the Golgi area, is supported by the finding observed in a fat-storing cell illustrated in Figure 20. In this fat-storing cell the cross section of a somewhat deformed centriole and the longitudinal section of an extraordinally elongated basal body are recognized side by side within a Golgi area embedded in a common homogeneous cytoplasmic area like the paired centrioles of the diplosome. From the distal end of the basal body protrude the single cilium into the deep invagination of the surface plasma membrane. The above picture may prove without any doubt the possible transformation of the centriole into the basal body.

Generally speaking, the fat-storing cells possess fairly well-developed granular 


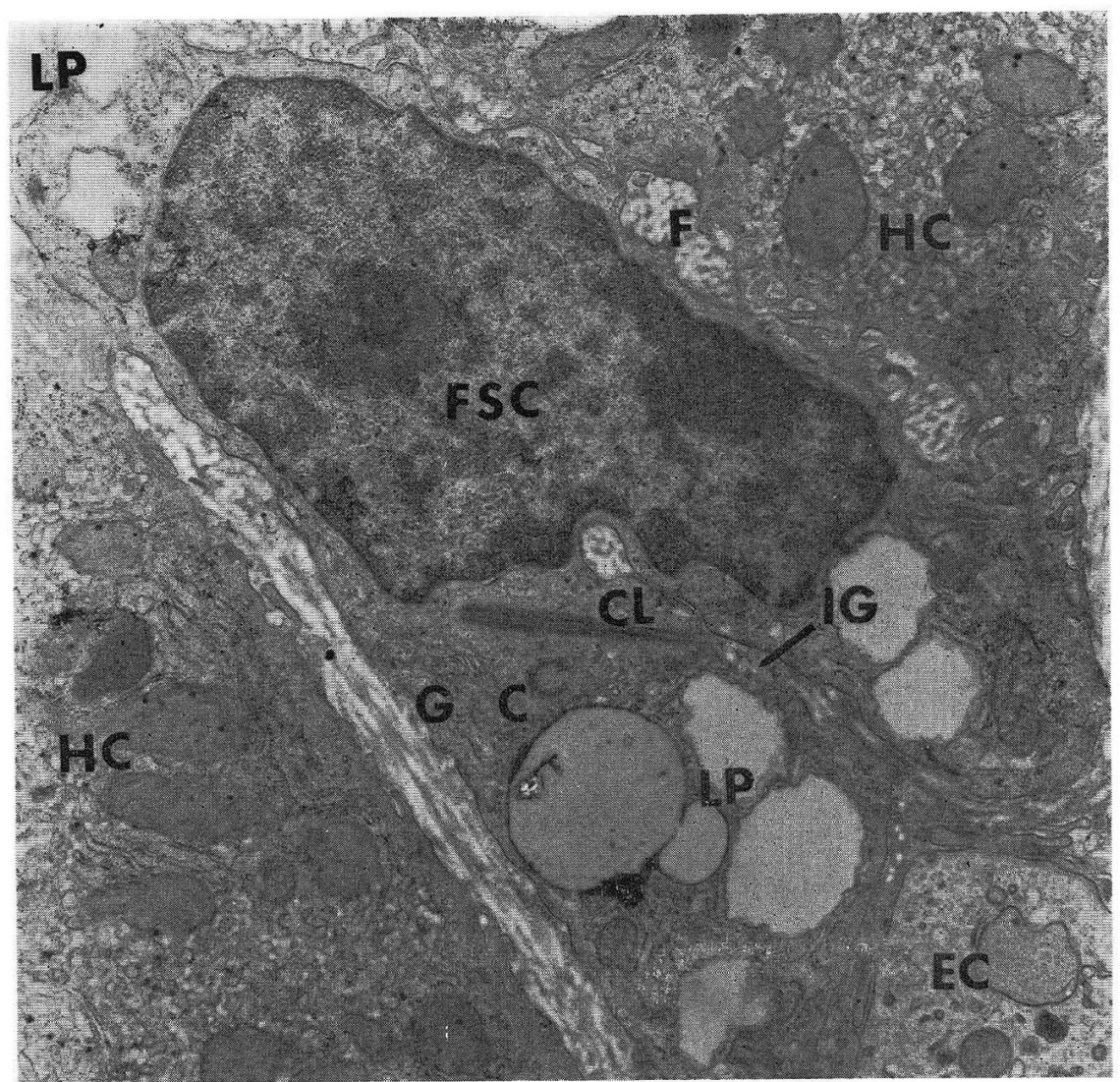

Fig. 20. A fat-storing cell $(F S C)$ in the perisinusoidal space characterized by occurrence of numerous collagen fibers $(F)$ and microvilli. The plasma membrane of the fat-storing cell shows a deep invagination ( $I G)$ containing collagen fibrils (clear). In the cytoplasm, there exist several fat droplets $(L P)$, mitochondria, granular endoplasmic reticulum and diplosome $(C)$ within the Golgi area $(G)$. One of the paired centrioles of the diplosome has become to the basal body which protrudes single cilium $(C L)$ into the invagination. $E C$ endothelial lining cell, $H C$ hepatocytes. $\times 9,300$

endoplasmic reticulum or ergastoplasm distributed throughout the whole cytoplasm. In the majority of them several elongated flattened sacs were encountered as the common components of the ergastoplasm, some of them are scattered randomly in the cytoplasm (Fig. 24, etc.), but many of them are associated with the mitochondria and the fat droplets, elongated along their surface (Fig. 12, 13, 20, 22, 24, etc.). A parallel array of some elongated flattened sacs showing lamellar pattern was rare and not prominent (Fig. 18). More or less dilated cisternae were also occasionally observed (Fig. 13, 16, 17, 23). Distribution of the ribosomes studded on the limiting membrane of the ergastoplasm is not uniform as seen in Figure 24. The content of the ergastoplasmic sacs shows some varieties of density. A considerable amount of free ribosomes aggregated into small clusters (polysomes) is observed scattered at random in the entire cytoplasmic areas (Fig. 18, 19, 24). The amount of ribosomes 


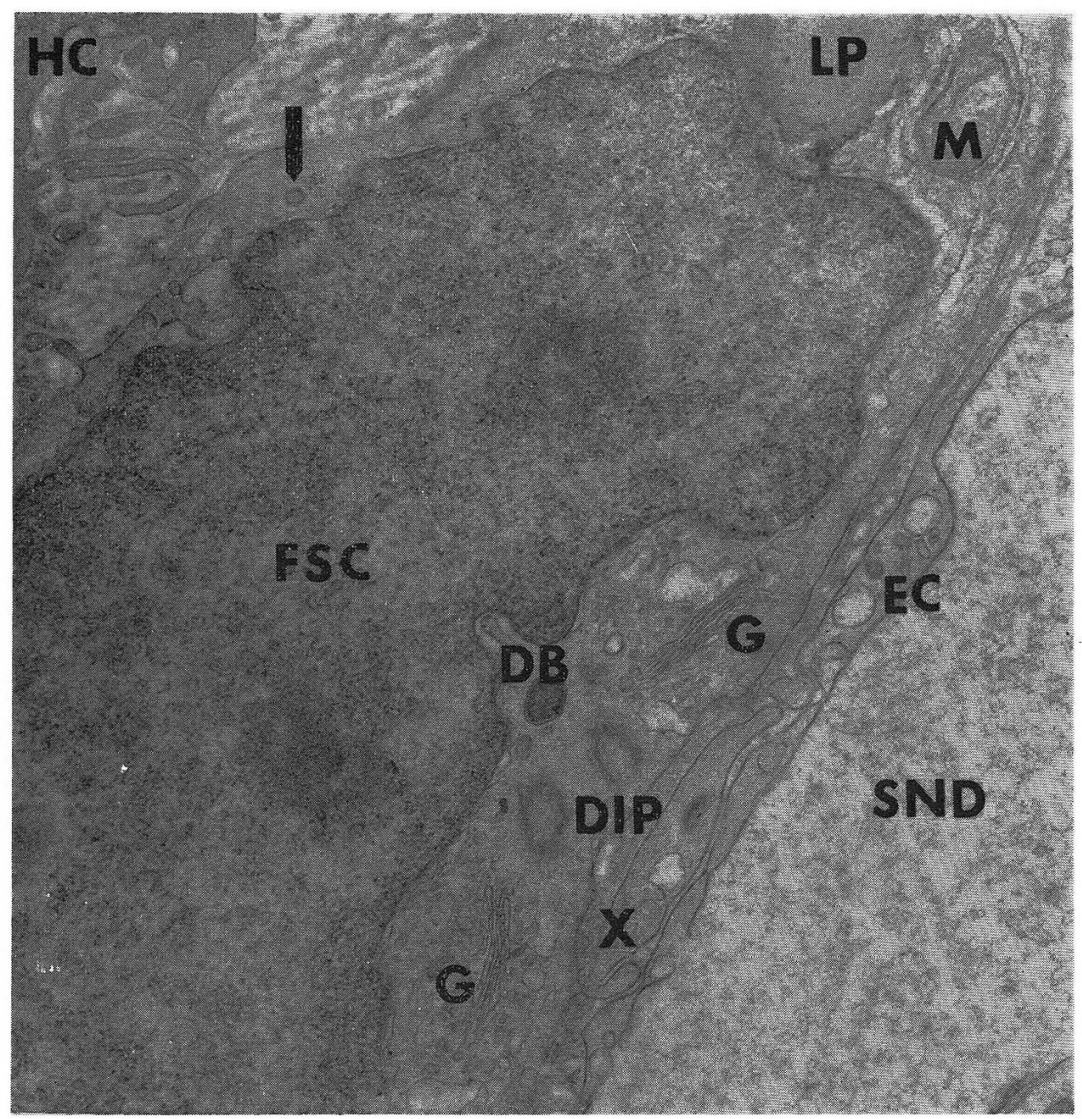

Fig. 21. A portion of a fat-storing cell $(F S C)$. In the cytoplasm Golgi complexes $(G)$ containing a diplosome $(D I P)$, dense body $(D B)$, mitochondrion $(M)$ with associated ergastoplasmic sacs, fat droplet $(L P)$, pinocytotic vesicles and a coated vesicle (arrow) are seen. In the narrow subendothelial space between the endothelial sheet $(E C)$ and the fat-storing cell there occur a subendothelial process $(X)$ of the fat-storing cell and some collagen fibrils (clear dots) indicating the innermost boundary of the perisinusoidal space. $H C$ hepatocyte, $S N D$ sinusoid. $\times 18,500$

studded on the external surface of the outer membrane of the nuclear envelope is surprisingly small.

Conspicuous components of the agranular or smooth endoplasmic reticulum are scarcely identified in the fat-storing cells except for the smooth membrane-bound components of the Golgi complex and the pinocytotic vesicles. The latter as well as the pinocytotic invaginations of the surface plasma membrane occur in the majority of the human fat-storing cells in considerable frequency (Fig. 25 and others), they are detectable along the entire surface plasma membrane including the plasma membrane lining the cytoplasmic projections and the deep invaginations (Fig. 15, 16, 19, $20)$. Among them scant so-called coated pinocytotic invaginations and vesicles are observed (Fig. 18, 21, 23, 24). In the fat-storing cell seen in Figure 24 a particular feature of the smooth endoplasmic reticulum is observed; abuting on both the cell surface 


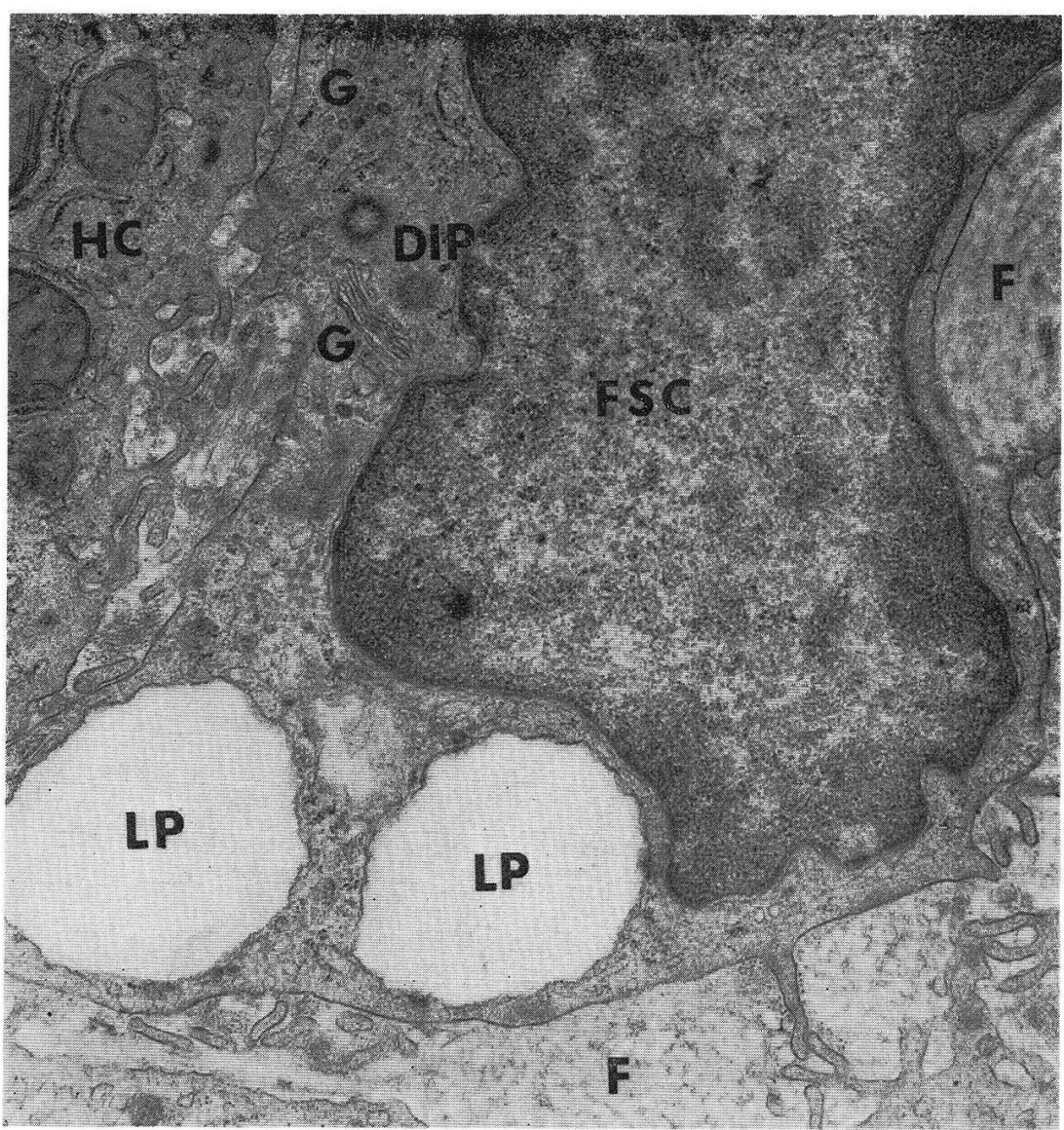

Fig. 22. A portion of a fat-storing cell $(F S C)$, which protrudes microvillous projections into the perisinusoidal space. In the cytoplasm Golgi complexes $(G)$ containing a transversely sectioned diplosome $(D I P)$, fat droplets $(L P)$, granular endoplasmic reticulum, free ribosomes and pinocytotic vesicles along the surface plasma membrane are identi-

fied. $F$ collagen fibers in the perisinusoidal space, $H C$ hepatocyte. $\times 16,300$

and the Golgi area containing the centriole there occur smooth membrane bounded canaliculi making a complex network. This conspicuous smooth endoplasmic reticulum may probably be induced by fusion of the pinocytotic vesicles. Along the canaliculi of the endoplasmic reticulum electron lucent minute areas are seen which may possibly correspond to the unstained glycogen particles. The evidence that the fat-storing cell possesses storage glycogen has been already light microscopically proved by ITo, TAhira and Tsunods (1953) and by Tsunoda (1955) in normal rabbit livers and normal human livers respectively.

Small dense bodies are frequently found in the cytoplasm of the fat-storing cells, they occur usually in small numbers and in random locations, sometimes in close proximity to the fat-droplets. Some of them are bounded by a distinct smooth limiting membrane and may surely be taken for lysosomes, but on the other hand there exist several dense bodies in which the limiting membrane is obscure in ultrathin 
sections. Especially in the latter case it is very difficult to distinguish them strictly from the small immature fat droplets.

The fat-droplets, the characteristic cytoplasmic inclusion bodies of the fat-storing cell, appear, as already noted above, as vacuoles containing electron lucent homogenous content or as quite empty. This finding might have been induced by unsufficient fixation of the lipid content of the fat droplets by osmic acid. As already light microscopically proved by Іто and Neмото (1952), the fat-storing cells of the human liver possess as a rule small fat droplets in large numbers, however, in ultrathin secions for electron microscopy the number of fat droplets (vacuoles) detectable in them was in general small as seen in Figures $10-24$. The fat-storing cells, in which a considerable number of fat droplets are visible, are sparse; in a fat-storing cell illustrated in Figure 26 ten fat droplets are recognized closely distributed on both

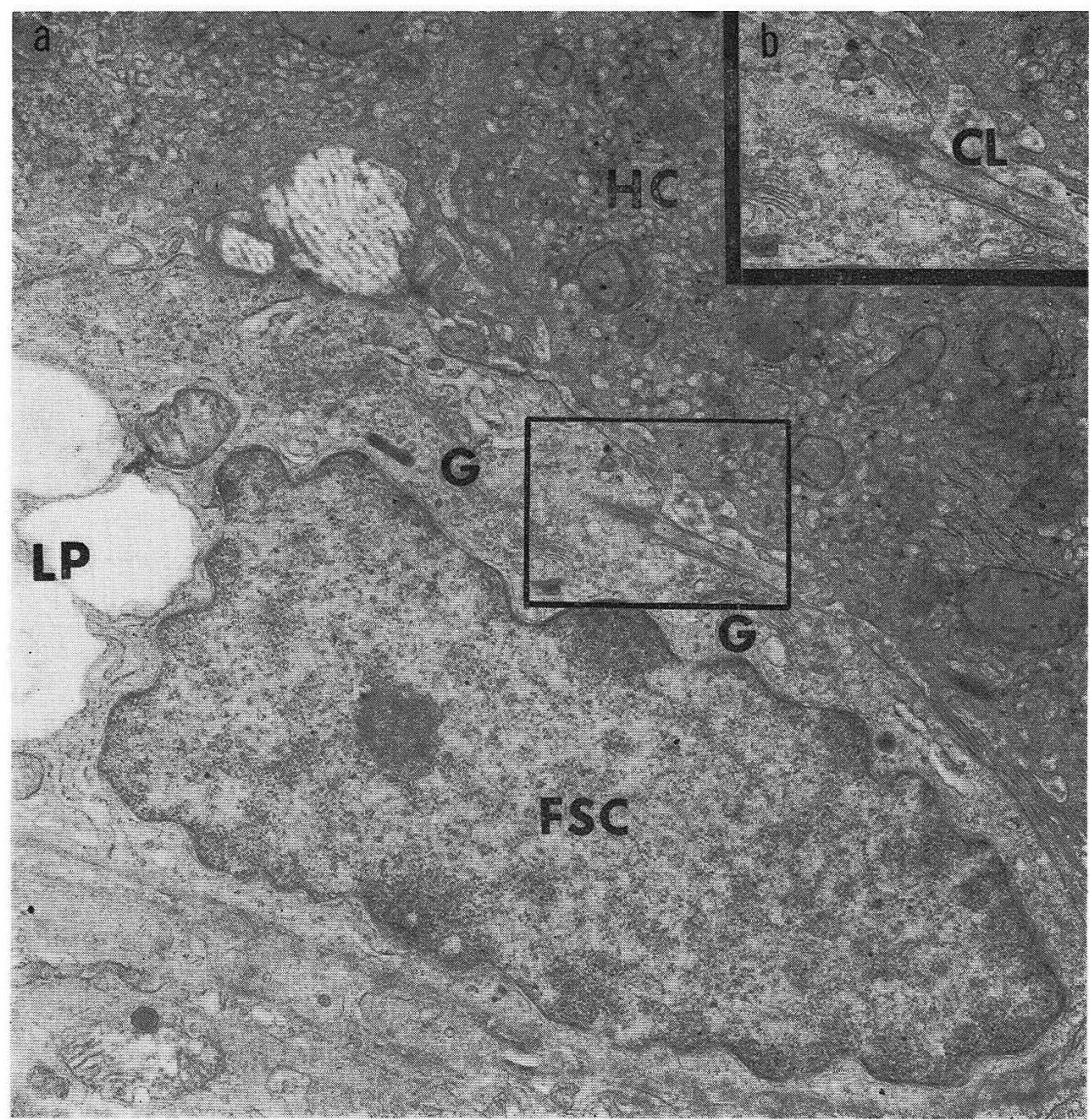

Fig. 23 a. A portion of a fat-storing cell $(F S C)$ containing several fat droplets $(L P)$ on one side of the nucleus. From a basal body situated just beneath the plasma membrane and within the Golgi complex $(G)$, a single cilium is protruded into the perisinusoidal space. $H C$ hepatocyte. $\times 6,200$.

b. Higher magnification of the part within the rectangle in Figure 23 a. $C L$ the single cilium projected from the basal body into the perisinusoidal space. $\times 13,000$ 
sides of the Golgi area containing the centriole, though the nucleus is not visible. The fat droplets, however, vary in size ranging from 2.9 to $0.8 \mu$ in diameter, they are almost spherical in shape, but their contours are tortuous or zigzag being limited by a distinct but weak smooth membrane. However, the frequent findings, that two fat droplets, which have come in close contact with each other, do not fuse into a larger one being separated by a thin membranous septum (Fig. 26, 20, 11, etc.). suggests the actual existence of a smooth membrane limiting each fat droplet.

Small spherical, probably immature fat droplets measuring about 1.0 to $0.3 \mu$ are occasionally found among the mature ones described above; they are somcwhat electron dense having a more osmiophilic marginal zone to which a few osmiophilic granules often adhere (Fig. 12, 26).

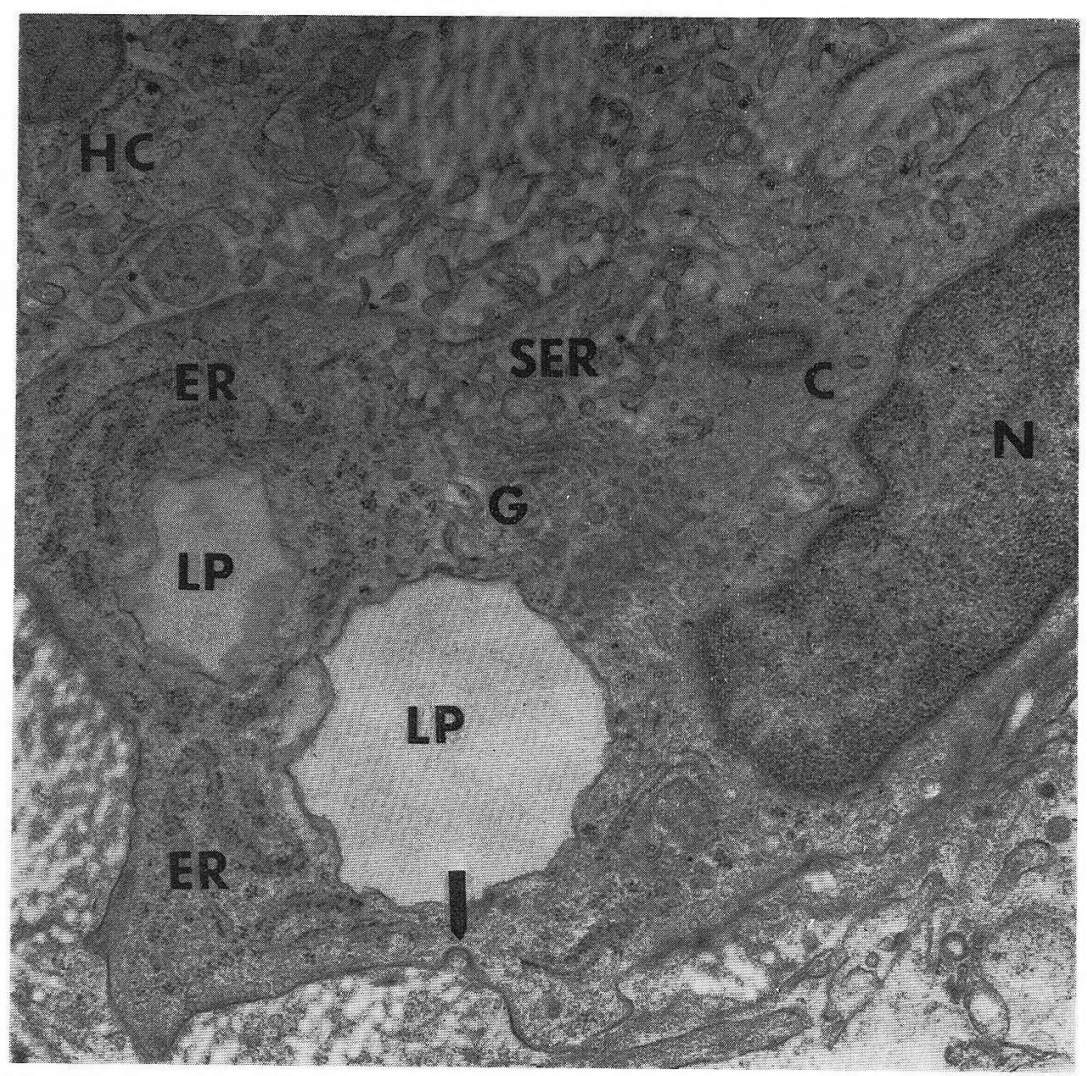

Fig. 24. A nucleus $(N)$ containing portion of a fat-storing cell in the perisinusoidal space which contains abundant collagen fibrils (clear) and microvilli of hepatocyte $(H C)$. In the cytoplasm numerous flattened sacs $(E R)$ of the granular endoplasmic reticulum, numerous clusters of free ribosomes, Golgi complex $(G)$, a centriole and a few mitochondria are seen, and above Golgi complex anastomosing canaliculi of the smooth endoplasmic reticulum $(S E R)$ and minute clear areas distributed along the canaliculi are observed the latter of which represent probably glycogen particles. Along the surface plasma membrane there occur numerous pinocytotic invaginations and vesicles arc found among which some bristle-coated ones (arrow) are detectable. 
The mechanism of fat synthesis and fat droplet formation in the fat-storing cells has not been elucidated. Here, we only focus special attention on the following findings which may offer suggestions concerning the site and mode of fat synthesis as well as fat droplet formation in the fat-storing cells : 1) The intimate topographical relations between the Golgi complex and the fat droplets are frequently observed as shown in Figures 14, 19, 20, 24 and 26. 2) As mentioned above, many pinocytotic invaginations and vesicles including bristle-coated ones have been revealed in the fat-storing cells indicating probably vigorous ingestion of material for fat synthesis. 3) The occurrence of small immature fat droplets of higher electron opacity among large mature ones may probably suggest the continual proceeding of fat synthesis as well as fat droplet formation in the fat-storing cells. The main question to be answered consists in the origin and the growth of the immature fat droplets.

The existence of the empty fat-storing cell containing no fat droplets was revealed

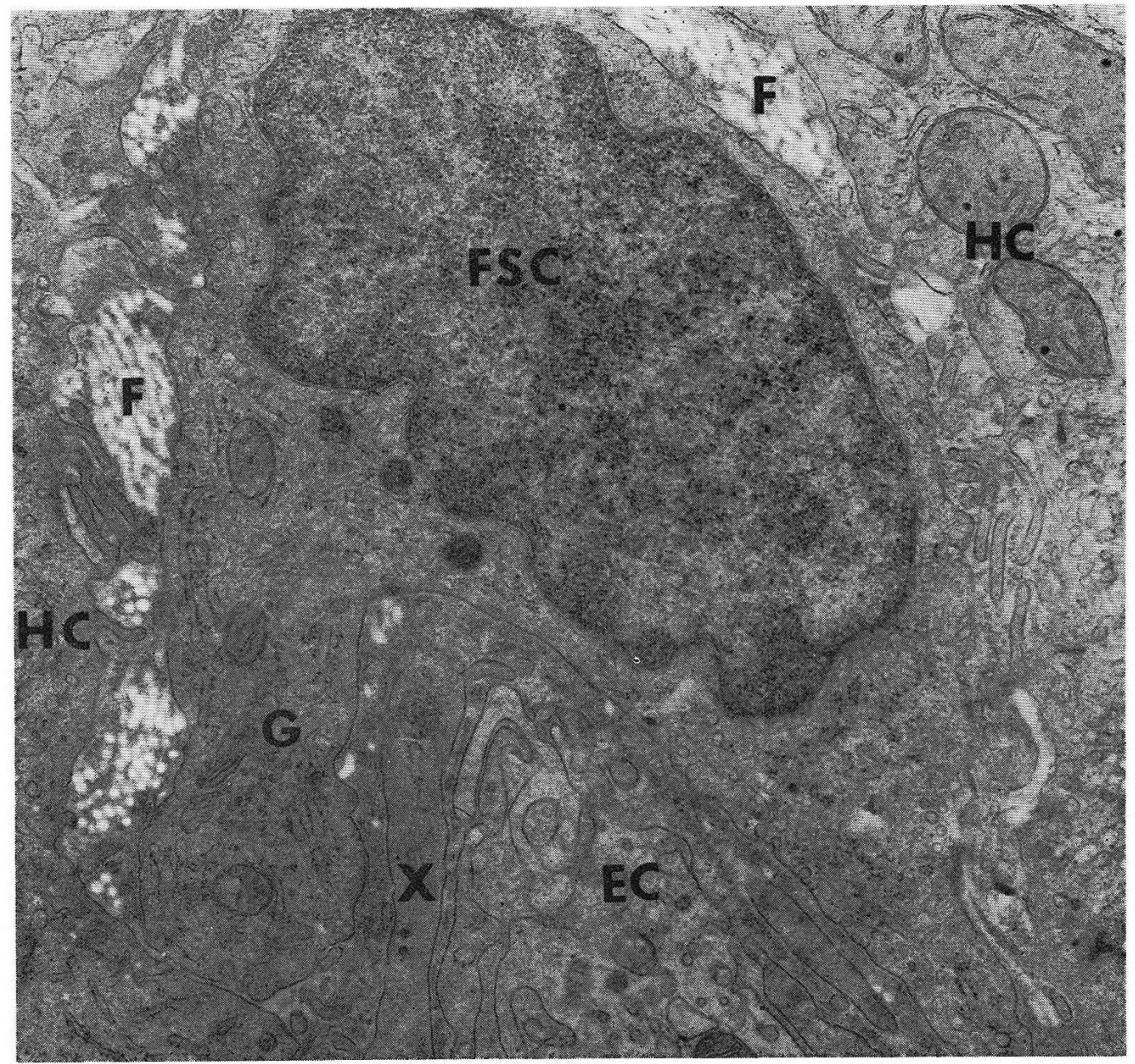

Fig. 25. A fat-storing cell (FSC) in which no fat droplets are detected. In the cytoplasm, there are observed numerous flattened sacs of granular endoplasmic reticulum, clusters of free ribosomes, Golgi complex $(G)$, mitochondria, small dense bodies and especially abundant pinocytotic invaginations and vesicles including coated ones along the surface plasma membrane. $E C$ endothelial cell lining the sinusoid, $F$ collagen fibrils in the perisinusoidal space, $H C$ hepatocytes, $X$ subendothelial process of the fat-storing cell closely apposed in parallel to the endothelial sheet. $\times 13,200$ 
by Iто and his co-workers in several light microscopic observations; according to them they occur as a rule in the central zone of the hepatic lobules, where fat-storing cells containing fat droplets are rare. In the present electron microscopic study occasional empty fat-storing cells were confirmed in normal human livers. In the empty cell illustrated in Figure 27 the cytoplasmic layer surrounding the nucleus is in general thin and contains a few mitochondria, a considerable amount of ergastoplasmic sacs elongated along the nuclear envelope, free ribosomes and many pinocytotic invaginations as well as vesicles. Several cytoplasmic processes are protruded into the Disse's space, especially a slender projection extending just beneath and parallel with the endothelial lining of the sinusoid is visible at the bottom right corner of this cell. Around the cell surface no basement membrane is identified. The above mentioned morphological properties of this cell agree with those of the typical fat-storing cells containing fat droplets. firmed.

The occurrence of the so-called pericytes in the Disse's space could not be con-

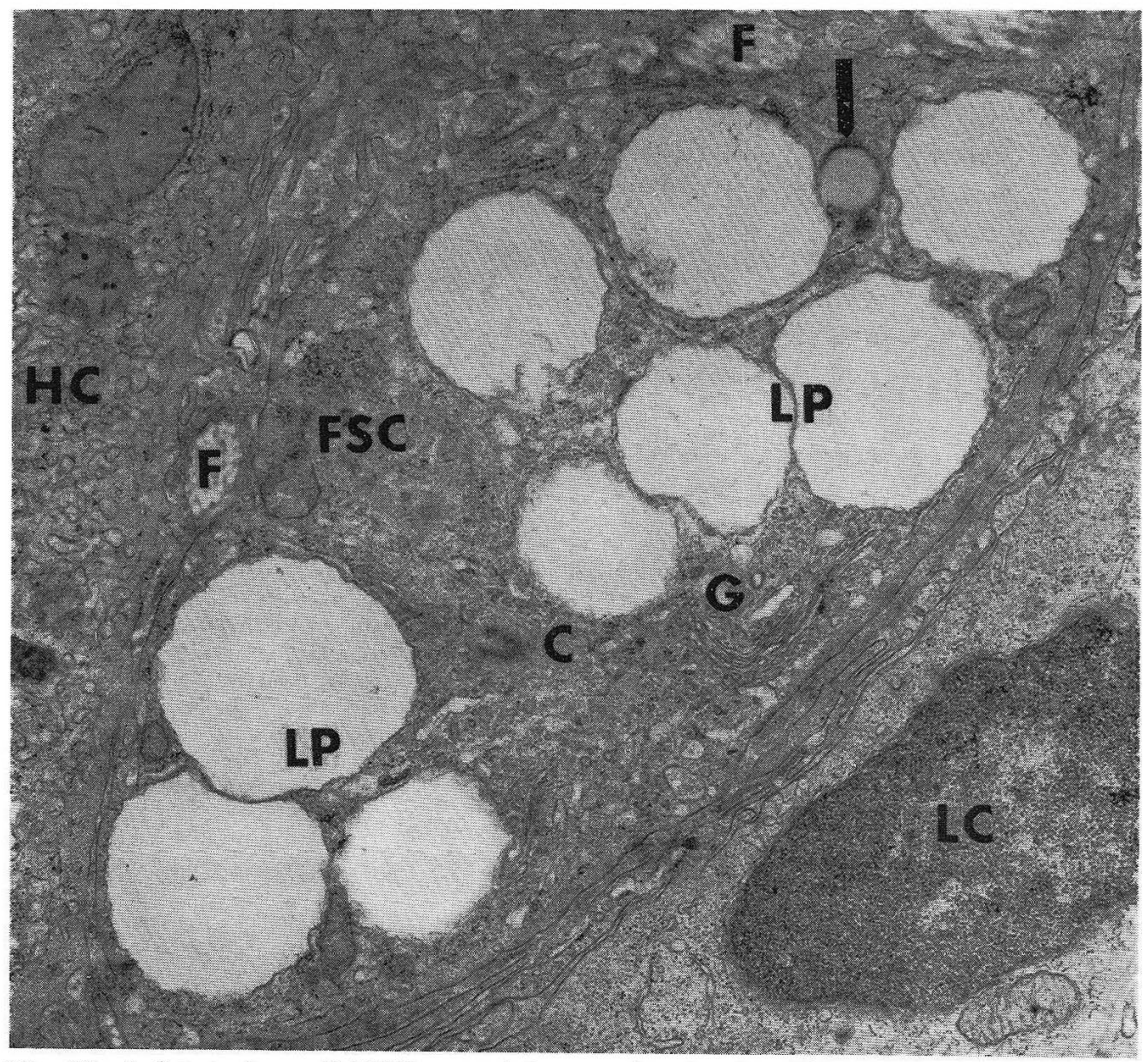

Fig. 26. A fat-storing cell $(F S C)$ containing ten fat droplets $(L P)$ among which a small immaturc one (arrow) of high electron density and with osmiophilic marginal zone is observed. In the cytoplasm, Golgi complex $(G)$ containing centriole $(C)$, flattened ergastoplasmic sacs, free ribosomes, mitochondria and pinocytotic vesicles are seen. In the sinusoid a lymphocyte $(L C)$ is found resting on the endothelial sheet lining the sinusoid. $F$ collagen fibers in the perisinusoidal space, $H C$ hepatocyte. $\times 8,700$ 
Round cells of an unknown nature were observed rarely in the Disse's space, one of which is shown in Figure 28. It is located in the perisinusoidal space being embraced by a large hollow of a hepatocyte. The cell surface is not even, though distinct processes like microvilli are absent, the pinocytotic invaginations and vesicles are not numerous. The oval, somewhat elongated nucleus contains two prominent nucleoli. The Golgi complex is located in a shallow indentation on one latcral side of the elon-

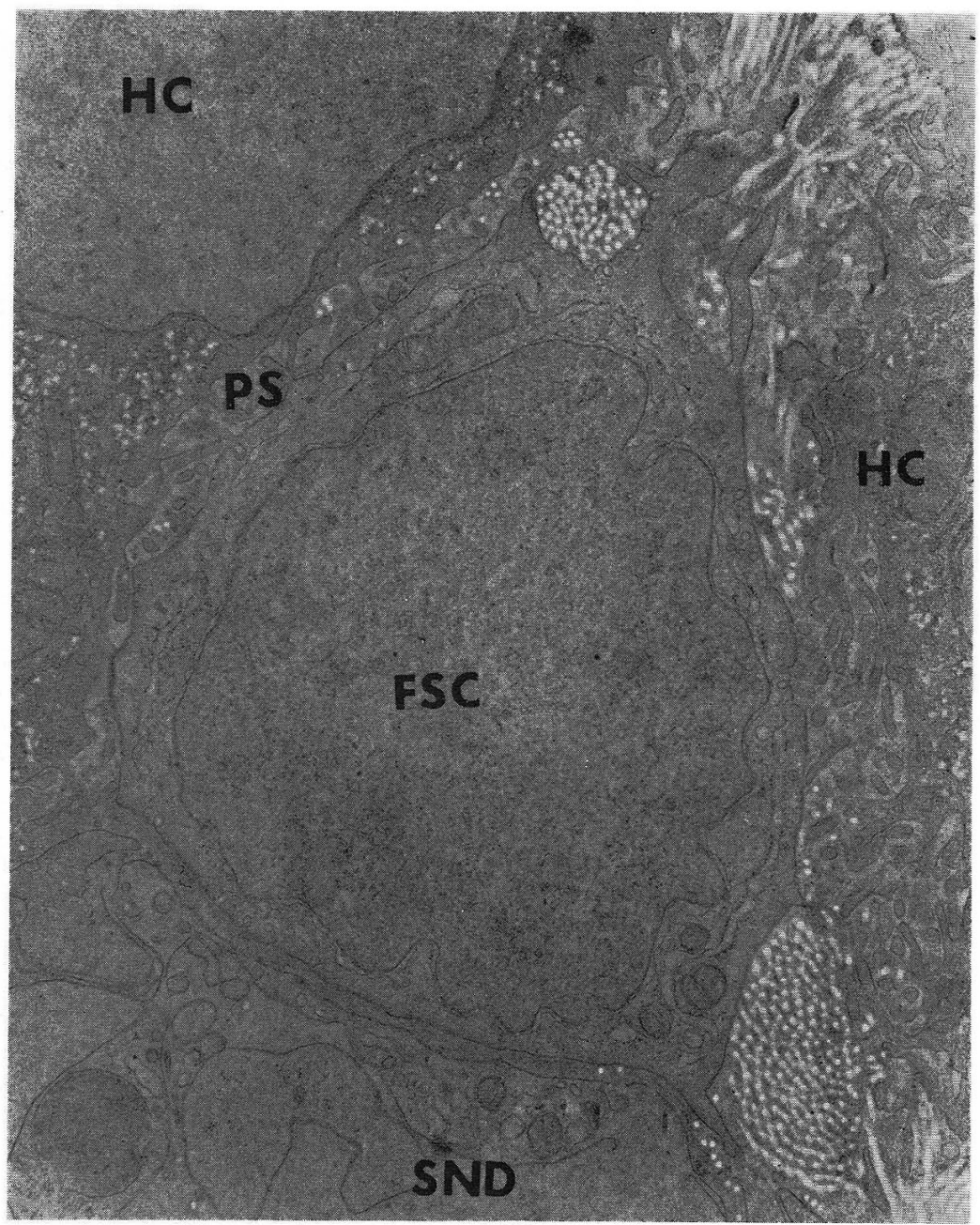

Fig. 27. A small empty fat-storing cell $(F S C)$ containing no fat droplet. It sends out several cytoplasmic processes into the perisinusoidal space $(P S)$ which contains collagen fibers and fibrils (clear) and microvilli of hepatocytes $(H C)$. This cell contains a round, relatively large nucleus and in the cytoplasm numerous flattened sacs of granular endoplasmic reticulum, small mitochondria and along the cell surface many pinocytotic vesicles and invaginations. The bottom surface of this fat-storing cell facing the sinusoid $(S N D)$ is separated by the endothelial cell from the latter. $\times 14,000$ 
gated nucleus, it is composed mainly of vesicles and vacuoles, but the development of the lamellae is poor. A considerable number of small round and rod-shaped mitochondria are irregularly distributed in the cytoplasm layer around the nucleus showing the tendency to make small groups. Numerous cisternae of the ergastoplasm of variable sizcs and shapes and numerous free ribosomes aggregated into small clusters are scattered throughout the cytoplasm. Besides these cell organelles, membrane-bound dense bodies (lysosomes), which are by far smaller than the mitochondria, are ob-

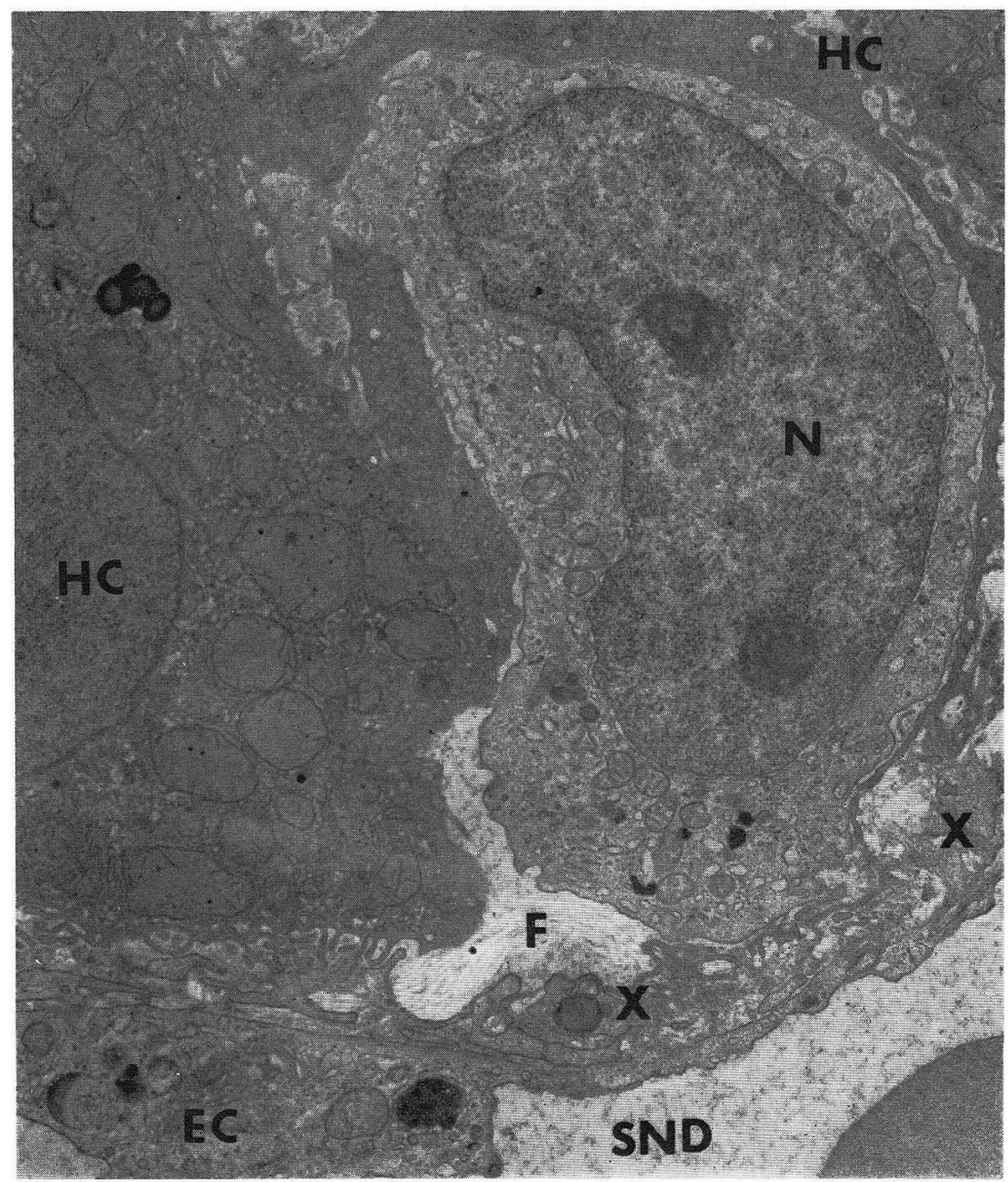

Fig. 28. A round probably hemopoietic cell in the perisinusoidal space, it is embraced in a large hollow of a hepatocyte $(H C)$. The elongated nucleus $(N)$ contains two nucleoli, in the cytoplasm, Golgi complex located in a depression on the nuclear membrane, numerous ritochondria, smooth vesicles, numerous ergastoplasmic sacs, numerous clusters of frec ribosomes and small dense bodies are observed. EC endothelial lining cell, $F$ collagen fiber in the perisinusoidal space, $S N D$ sinusoid, $X$ subendothelial cytoplasmic extensions of the fat-storing cell, one of which contains a fat droplet (dark). $\times 6,900$ 
served. On the basis of the above mentioned ultrastructural properties we could not dare to identify this questionable cell with an empty fat-storing cell; it should be a cell type quite different from the latter. The question whether or not any hemopoietic cells occur in the Disse's space will be answered if the questionable cells concerned were identified with the stem cells of the blood corpuscle.

Unmyelinated nerve fibers: Recently, YAMADA (1965) has for the first time revealed by electron microscopy unmyelinated nerve fibers in the Disse's space of the mouse liver and observed in detail their relationships to the hepatocytes. In his observation he did not encounter, however, the nucleated portion of the Schwann cells. In the present electron microscopic study on normal human livers we could find frequently in the Disse's space small bundles of the unmyelinated nerve fibers sheathed by the Schwann cell cytoplasm.

In Figure 29 we can see two nucleus containing portions of the Schwann cell in the Disse's space filled with thick collagen fibers. One nucleated portion contains an oval profile of the nucleus and is located just beneath the endothelial lining of the sinusoid being separated by a narrow subendothelial space from the latter. As widely known, the Schwann cell is surrounded by a distinct basement membrane; in this case, along the surface facing the subendothelial space a basement membrane, though not continuous, is visible. It is a noteworthy finding that a well-defined basement membrane is also apparently identified along the external surface of the endothelial cell facing this subendothelial space which is independent of that of the Schwann cell being separated from the latter by an electron lucent layer. The nucleus of the Schwann cell is chromatin-rich and appears dark, containing a small nucleolus. The cytoplasm possesses a considerable amount of rough-surfaced endoplasmic reticulum, scanty mitochondria, occasional membrane bound small dense bodies or lysosomes and along the surface plasma membrane several pinocytotic vesicles. The small Golgi apparatus is demonstrated near the nucleus which consists of lamellae, vacuoles and vesicles. The above described nucleated portion just beneath the endothelial lining of the sinusoid encases, however, no nerve fibers or axons. Another nucleated portion abutting on the right side of the former encases several nerve fibers sectioned transversely, and some of them contain in the axoplasm a few membrane bound vesicles of about $500 \AA$ in diameter which contain homogeneous material. This Schwann cell embraces a thick collagen fiber with a thin cytoplasmic projection protruded around the latter. In a narrow space between these two Schwann cells a single basement membrane is identified which is continuous with those covering the perisinusoidal surfaces of both cells. Figure 30 illustrates a cross sectioned nerve bundle within the perisinusoidal space. Between this nerve bundle and the endothelial lining of the sinusoid, the perisinusoidal space is occupied by collagen fibers, but the spaces between the nerve bundle and the hepatocytes are mainly filled with abundant microvilli protruded from the latter which are distributed irregularly up to close proximity to the nerve bundle. Seven axons are enclosed in a Schwann cytoplasm which contains elements of a rough endoplasmic reticulum and a small mitochondrion. Except for a rather longitudinally sectioned axon in the center of the nerve bundle, axons contain a number of membrane bound vesicles filled with a homogeneous material, but especially in one axon found on the upper 


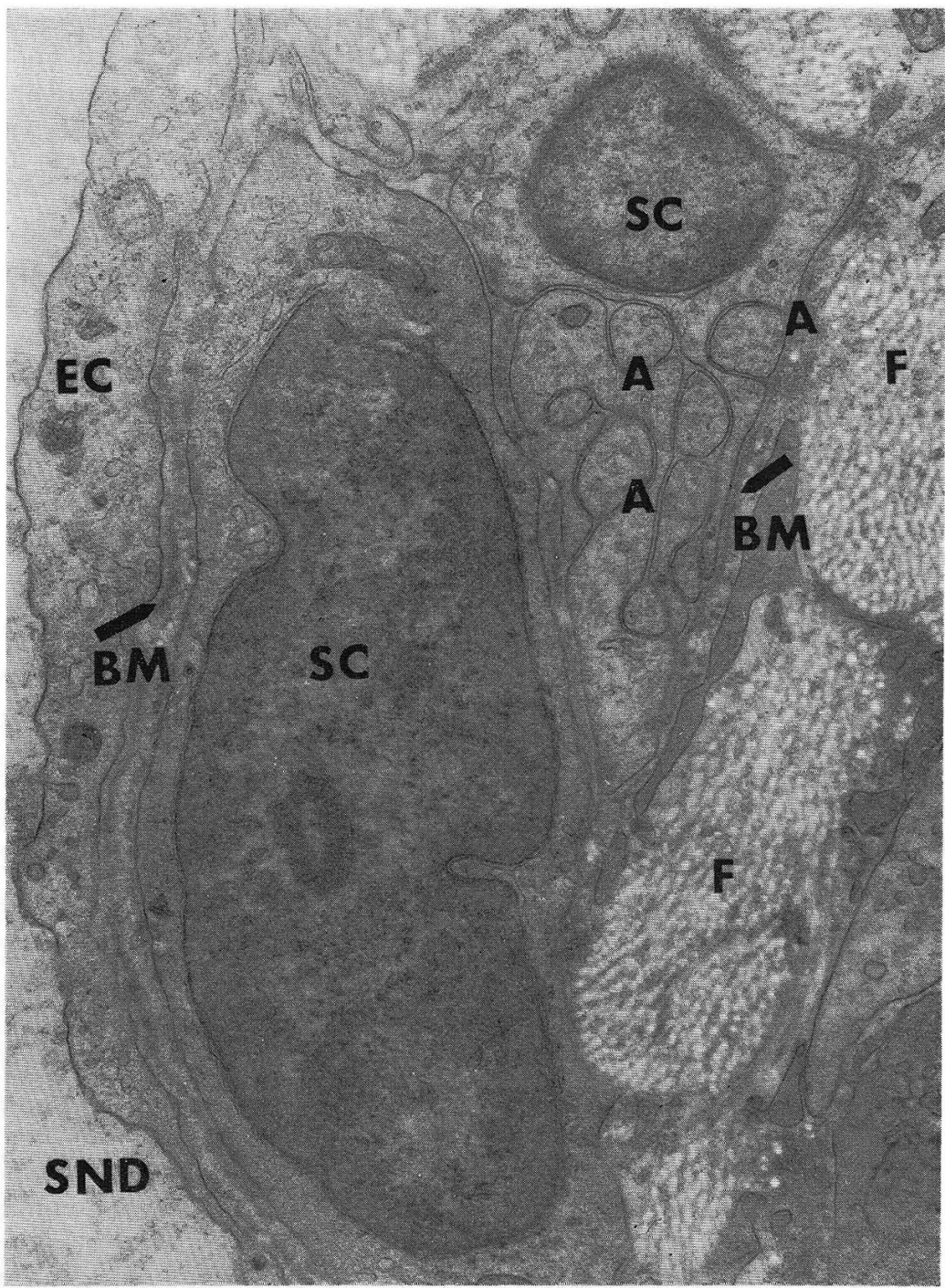

Fig. 29. Two Schwann cells containing nucleus found in the perisinusoidal space just beneath the endothelial sheet $(E C)$ lining the sinusoid $(S N D)$. Each of the Schwann cells is surrounded by a rather thick basement membrane $(B M)$ and on the perisinusoidal surface of the endothelial sheet facing a Schwann cell a welldefined basement membrane $(B M)$ also occurs. In the Schwann cytoplasm, thcre are seen a chromatin-rich nucleus, a considerable amount of granular endoplasmic reticulum, sparse mitochondria and unmyelinated axons $(A) . F$ collagen fibers in the perisinusoidal space. $\times 19,700$.

margin there occurs, besides numerous vesicles as described above, a small number of vesicles with a cored granule of high electron density. This vesiculated axon lacks on the upper surface the covering of Schwann cytoplasm where the axon plasma membrane is naked facing directly the microvilli of the hepatocyte. The membrane 


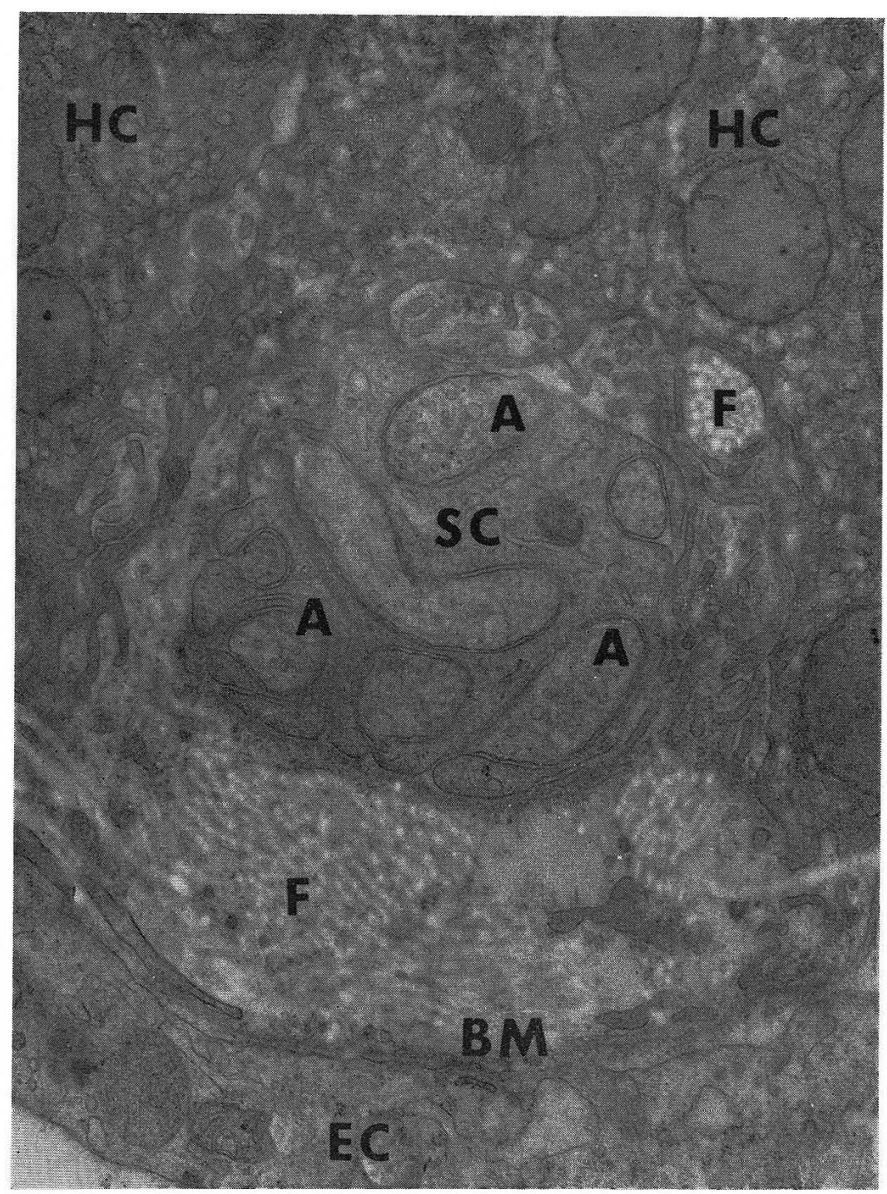

Fig. 30. A cross scction of a small, unmyclinated nerve bundle in the perisinusoidal space. Some axons $(A)$ coataining agranular and granular vesicles. $B M$ basement membrane, $E C$ endothelial lining cell of the sinusoid, $F$ collagen fibers in the perisinusoidal space, $H C$ hepatocytes protruding numerous microvilli into the perisinusoidal space. $S C$ Schwann cytoplasm. $\times 22,000$

bound vesicles contained in the vesiculated axon which probably corresponds to the so-called "vesiculated nerve process" (Honjın et al. 1965), may possibly be identical with the synaptic vesicles and so the vesicles with a homogeneous, less dense content ( $500 \AA$ in diameter) may be identified with the so-called agranular or empty synaptic vesicles and those with a dense granular core with the so-called granular synaptic vesicles. They measure about $800 \AA$ and $500 \AA$ in diameter respectively. A cleft between the axon membrane lining the enclosed axon and the parallel opposed plasma membrane of the covering Schwann cytoplasm measures about $200 \AA$ in width.

The cross section of the nerve bundle illustrated Figure 31 exists in the Disse's space just beneath the endothelial lining of the sinusoid which is overlapped from 


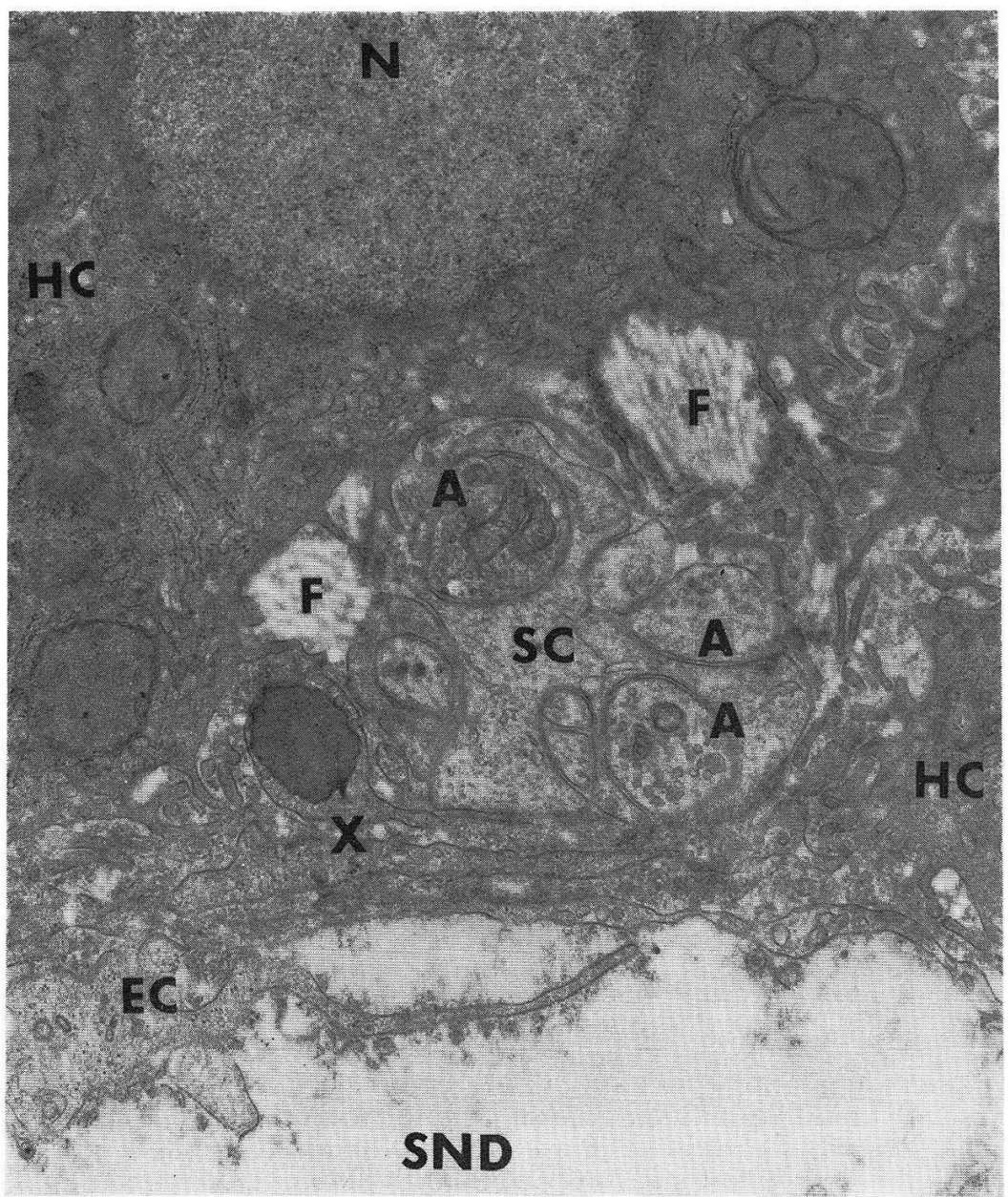

Fig. 31. A cross section of a small unmyelinated nerve bundle running in the perisinusoidal space. Axons $(A)$ encompassed in the Schwann cytoplasm $(S C)$ contain agranular and sparse granular vesicles as well as small mitochondria. $E C$ endothelial lining cell sending out into the sinusoid $(S N D)$ a long slender process, $F$ collagen fibers in the perisinusoidal space, $H C$ hepatocytes protruding numerous microvilli into the perisinusoidal space, $N$ nucleus of hepatocyte, $X$ subendothelial processes of the fat-storing cell, one of which contains a fat droplet (dark). $\times 12,600$

the perisinusoidal side by a thin cytoplasmic process of a fat-storing cell. It contains some vesiculated axons which have somewhat larger diameters as compared with those observed in Figure 30. An expanded vesiculated axon encased in the bottom right corner of the Schwann cytoplasm contains a small accumulation of empty vesicles and small mitochondria, however, the granular vesicles are not visible. This vesiculated axon possesses no mesaxon and the small bottom part of the axon membrane is naked. The similar vesiculated axon found above this one is embraced in common with another smaller one by the Schwann cytoplasm, but the axon membrane is exposed in the Disse's space to a large extent and the long naked 
part of the axon membrane abuts on the microvilli of the hepatocyte, in the same direction a small accumulation of the empty vesicles is polarized. The most prominent accumulation of abundant agranular vesicles and a small number of granular ones associated with an accumulation of the mitochondria is found in an expanded vesiculated axon encased in the upper left corner of this Schwann cytoplasm. The left half of the axon membrane is naked abutting directly on the microvilli of the hepatocyte. Near the bottom left corner of this Schwann cytoplasm there exists in the Disse's space a small piece of the electron dense cytoplasm which may be without any doubt taken for a cytoplasmic process protruded from a fat-storing cell, because of the evidence that it contains a fat droplet. Another cytoplasmic fragment with a similar density occurs between this process and the Schwann cytoplasm closely applied to the latter and encloses a small axon. If this questionable cytoplasmic fragment might actually be a process or a peripheral part of a fat-storing cell, it must be concluded that the axon penetrates into the fat-storing cell as in the case of the hepatocyte (Yamada 1965). Between the opposed plasma membranes

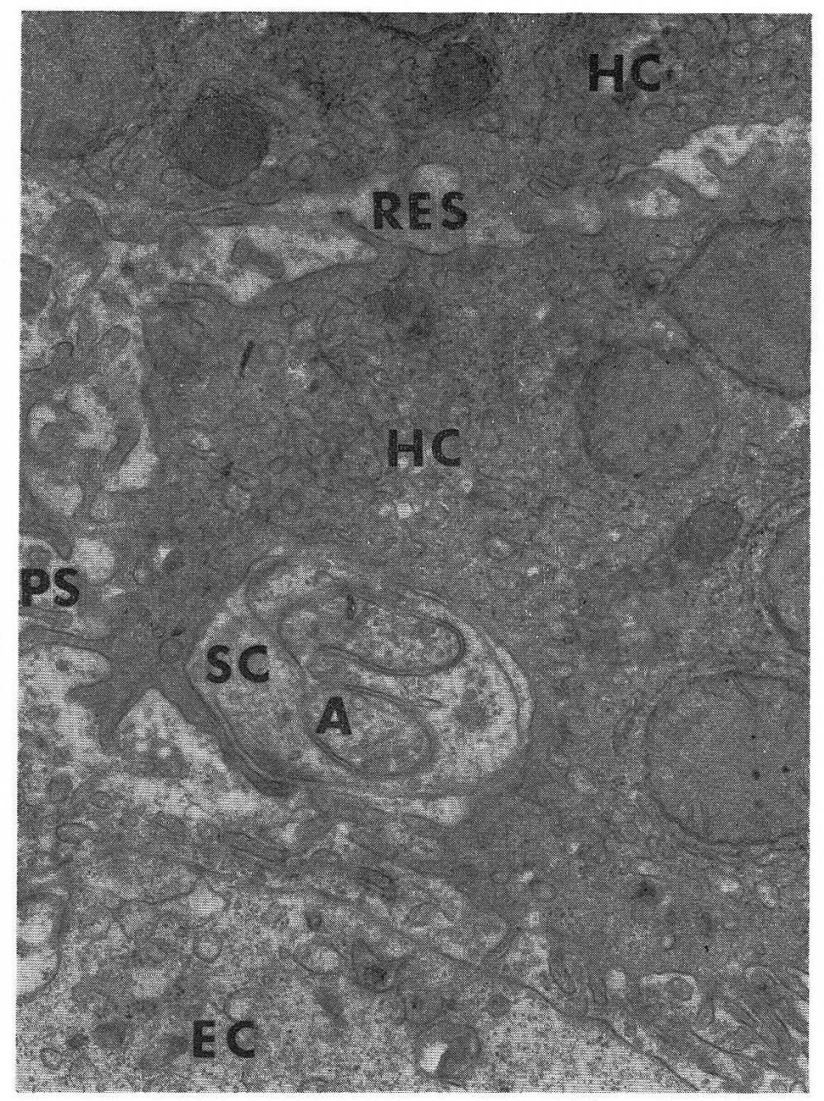

Fig. 32. A small nerve bundle consisting of two axons $(A)$ embraced in the Schwann cytoplasm $(S C)$. It is found in a hollow on the perisinusoidal surface of a hepatocyte $(H C)$ and just beneath the endothelial cell $(E C)$ of the sinusoid. PS perisinusoidal space, $R E C$ recessus. $\times 17,700$ 
limiting the axon and the cytoplasmic fragment respectivcly a minute intcrcellular slit as found between the axon and the Schwann cytoplasm is recognized. Further, small nerve bundles were often in the hollows present on the perisinusoidal surface of the hepatocytes; the axons were, however, in the majority of cases sheathed by the Schwann cytoplasm as seen in Figure 32. In this study we could not encounter the naked axons running within the hollows on the surface of the hepatocytes or penetrating into the cytoplasm of the latter, though YAMADA (1965) could reveal in the mouse liver naked axons which penetrated singly into the cytoplasm of the hepatocyte to make contact with the latter directly. The profiles of the two axons contained in the above described nerve bundle (Fig. 32) possess several synaptic vesicles suggesting that they may be probably not so far distant from the nerve terminals or the "vesiculated nerve processes" in which they might become naked to make the synaptic contacts with the hepatocyte.

In Figure 33 a nerve bundle sectioned in part longitudinally runs in the Disse's space between a fat-storing cell and the hepatocytes. In the axoplasm of the longitudinally sectioned axons neurofilaments and neurotubuli are observed. The longi-

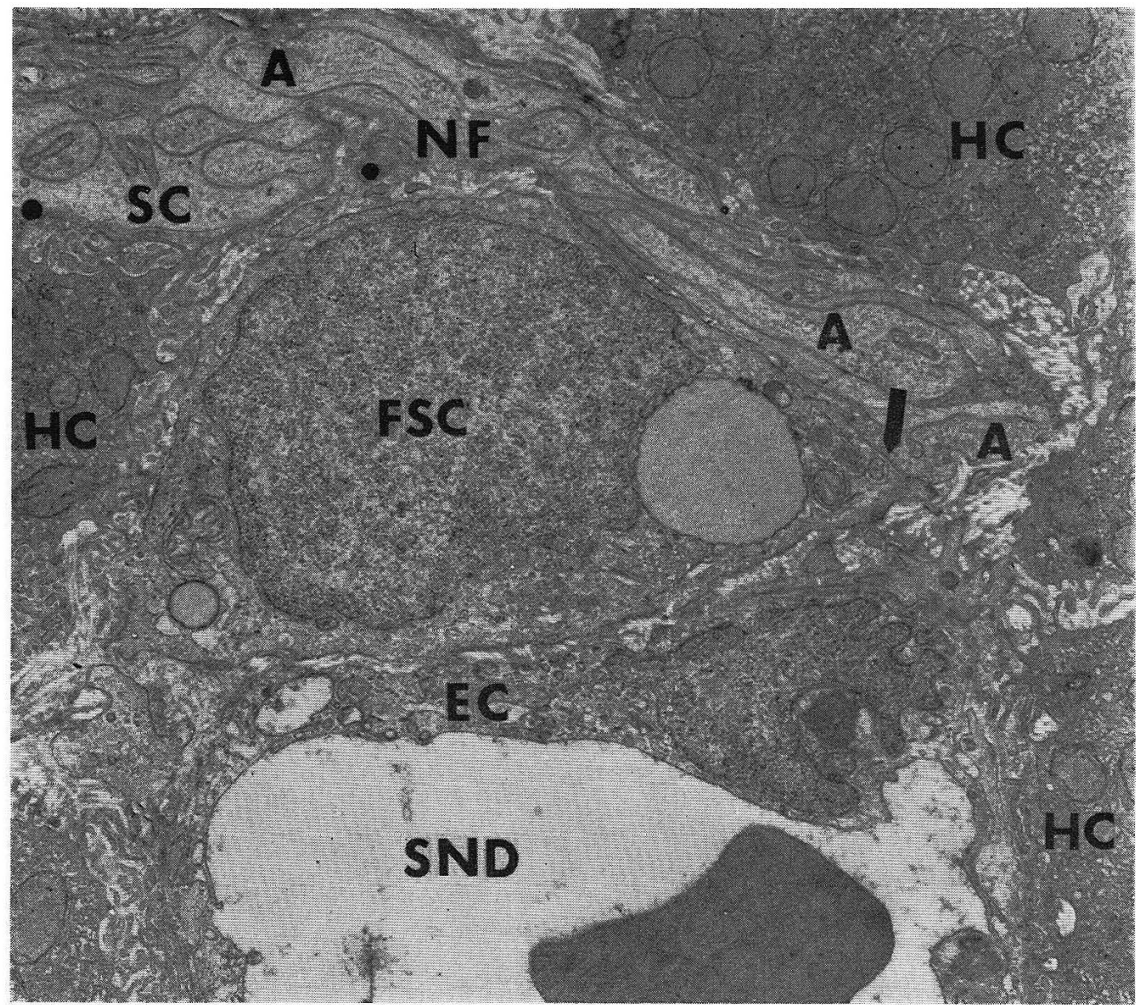

Fig. 33. A longitudinal section of a small unmyelinated nerve bundle $(N F)$ running between a fat-storing cell $(F S C)$ and a hepatocyte $(H C)$. The axons $(A)$ show from place to place varicosities containing vesicles and occasionally small mitochondria. At the lower right end of the nerve bundle a naked axon containing vesicles and mitochondria comes in direct contact with the fat-storing cell (arrow). EC endothelial lining cell, SND sinusoid containing an erythrocyte. $\times 6,000$. 
tudinally cut axons show somewhat expanded portions in which the accumulation both of the agranular as well as granular vesicles and of the small mitochondria are demonstrated. The agranular vesicles always predominate in number over the granular ones. One expanded portion found in the bottom right end of the nerve bundle is naked except for the upper boundary facing the Schwann cytoplasm and exists in direct contact with the fat-storing cell being separated by a narrow intercellular slit measuring about $200 \AA$ in width from the latter. Another one found in the middle part of the upper right boundary of this nerve bundle has also long naked surface which contacts with microvilli of a hepatocyte. Other expansions seem as if they are embedded in the Schwann cytoplasm. The above described expanded portions of the axon may correspond to the vesiculated axons found in the cross sections of the nerve bundle and probably to the "vesiculated nerve processes" of previous authors (Honjin et al. 1965). According to Honjin et al. the vesiculated nerve processes represent the "varicosities" which are often seen along the fine nerve bundles in the most peripheral part of the autonomic nervous system examined with the light microscopic technics.

\section{Discussion}

The problem concerning the discontinuity or continuity of the endothelial lining of the hepatic sinusoid has been studied by many investigators in several mammals with the electron microscope. Since Fawcetr (1955) discovered the discontinuity of the hepatic sinusoidal lining, the majority of the investigators have confirmed his findings in several mammals (Parks 1956, Rüttner and Vogel 1957, Hampton 1958, Wassermann 1958, Yamagishi 1959, Matsuo 1959, Bennet et al. 1959, Cossel 1959 b, c, 1962, Horiuchi 1960, Steiner 1961, Roulller et al. 1963, Kuhn et al. 1965, Tanikawa et al. 1965, Sahnack et al. 1966). Only Wood (1963) has found in the calf liver the continuous endothelial lining of the sinusoid. He examined for purposes of direct comparison the liver sinusoid of the rat following identical methods of preparation and confirmed the discontinuity of the sinusoidal lining. As the result he came to the conclusion that there exists a species difference in the hepatic sinusoidal lining. It has been revealed by many of the above mentioned investigators that the gaps or fenestrations found in the endothelial lining of the sinusoid are intercellular in nature (Rüttner and Vogel 1957, Parks 1956, Cossel 1959 b, Bennet et al. 1959, Rouiller et al. 1963, Tanikawa et al. 1965). Cossel (1962) alone, however, classified the gaps into intercellular and intracellular ones proposing that the grades of their manifestation might be due to the functional state of the liver.

As noted by Aterman (1963) the mode of the connection of the neighboring endothelial lining cells of the hepatic sinusoid is a matter of great interest, and a number of investigators have paid attention to this problem. HAMPTON (1960) maintained that unlike the endothelial cells in other capillaries, the liver sinusoidal endothelial cells did not appear to be bound together at their margins and no desmosomes could be recognized, whereas Parks (1956), Rüttner and Vogel (1957), and Cossel (1959b) demonstrated the overlapping of free edges of the endothelial lamellae without being bound with the terminal bar or desmosomes. Sahmid (1960), however, revealed a narrow zone (about $300 \AA$ in width) of electron dense material between the apposing plasma membranes, which line the free edges of the neighboring endothelial 
lamellae. In the present study on the normal human livers we could demonstrate a distinct cell connection between the endothelial cells of the sinusoid; the free edges of the neighboring endothelial sheets overlapped like roof tiles and a minute slit about $200 \AA$ in width was maintained between the juxtaposed plasma membranes lining the free edges; no well-defined junctional structures as a terminal bar and desmosomes were recognized. It seems impossible that these cell connections between sinusoidal endothelial cells might easily be detached according to the physiological conditions making intercellular gaps or interruptions. So we believe that the discontinuities seen in the endothelial lining of the hepatic sinusoid should entirely be intracellular structures which correspond to the endothelial pores or fenestrations found in other common blood capillaries but seem to permit the free penetration of the blood plasm from the sinusoid into the perisinusoidal space or vice versa and to exercise no selective filtering effect on blood plasm constituents smaller than platelets as proposed by BENNET et al. (1959).

It is widely accepted that the endothelial lining of the hepatic sinusoid of the common laboratory animals and human beings does not possess any continuous typical basement membrane (Rüttner and Vogel 1957, Wassermann 1958, Yamagishi 1959, Matsuo 1959, Cossel 1959 b, Bennet et al. 1959, Wood 1963, Tanikawa et al. 1965, KuHN et al. 1965, SahNAGK et al. 1966), though a continuous basement membrane surrounding the sinusoid has been recently demonstrated in the calf and goat by Wood (1963) and KuHN and Olivier (1965) respectively. That it may appear also in human livers in several pathologic states was reported by some authors (Sahnack et al. 1966, Safran and Sahaffner 1967, etc.). Further, Rouiller and JÉzéQuel (1963) could distinguish in the normal human liver stained with lead according to KARNOVsKY (1961) a material similar to that of a basement membrane along the sinusoidal endothelial cells. In the present study on normal human livers the continuous typical basement membrane has not been revealed along the sinusoidal lining, though in some places short basement membrane-like materials were observed just beneath the endothelial linings. Therefore, we should not completely deny the existence of the basement membrane; this attitude is supported by a finding obtained in this study that, in some areas where the Schwann cell with its proper basement membrane occurs close to the endothelial lining, a well-defined continuous basement membrane appears along the surface of the endothelial lining facing the Schwann cell, separated by a narrow space from that surrounding the latter.

In their electron microscopic studies on the hepatic sinusoidal wall many investigators pointed out the frequent occurrence of the overlapping of two or more endothelial sheets lining the sinusoid (RÜTtNer and Vogel 1957, Y Amagishi 1959, Matsuo 1956, Gossel 1959a, b, Steiner 1961, Wood 1963, Kuhn and Olivier 1965, TaniKAWA et al. 1965). Rüttner and Vogel (1957) and Yamagishi (1959) thought that the overlapped cytoplasmic lamellae might be cytoplasmic extensions either of one and the same endothelial cell or of the adjoining ones. In his review on the hepatic sinusoid ultrastructure Aterman (1963) has classified the endothelial lining of the hepatic sinusoid into the following four types: 1) a single sheet, 2) the overlapping cells, 3) the laminated appearance of two or more layers and 4) the appearance of a veritable labyrinth. This classification was done, however, regardless of the origin of the overlapped or laminated cytoplasmic sheets. In the present study we encoun- 
tered here and there in the human hepatic sinusoidal wall the cytoplasmic sheets stratified mostly in two layers, of which only the innermost layer could be identified with the cytoplasmic projection of the endothelial cell, whereas all others following closely on its outside were identified with the subendothelial projections of the fatstoring cells located in the perisinusoidal space. They are distinguished from the endothelial sheet with the higher electron density of their matrix. They contain in general numerous pinocytotic vesicles and sometimes elements of granular endoplasmic reticulum and free ribosomes. In this way, we came to the conclusion that the endothelial lining of the hepatic sinusoid is principally simple and the cytoplasmic pieces apposed on its outer surface pretending the overlapping of the endothelial elements were proved to be the sections of the subendothelial fat-storing cells which might reinforce the endothelial lining of the sinusoid. Thus, we can not appropriately understand the fine structure of the hepatic sinusoidal wall without knowing the presence of the perisinusoidal fat-storing cells.

Gytological comparison between the Kupffer cell and the endothelial lining cell has been made by many investigators engaged in the electron microscopic studies on the hepatic sinusoidal wall and the majority of them are of the opinion that both types of cells are identical (Rüttner and Vogel 1957, Steiner 1961, Kuhn and Olivier 1965, Nigolescu and Rouiller 1967, etc.). Aterman (1963) actually described that the distinction between "lining cells" and "phagocytic cells" appears to have lost much of its interest under the electron microscope. Most authors have confirmed the existence of "active endothelial cells" which exhibit in their perikarya fine structures suggesting phagocytic activities (RütTnER and Vogel 1957, HashIмото et al. 1958, Yamagishi 1959, Matsuo 1959, TAnikawa at al. 1965). The present findings also indicate the similarity of the both cell types by proving almost constantly phagosomes or phagocytic vacuoles in the perikarya of the endothelial cells. On the other hand, however, there are recognized several ultrastructural differences between both cell types : 1) As compared with the perikarya of the endothelial cells, Kupffer cells are much more voluminous cells projected extensively into the sinusoidal lumen. Moreover, they are lacking in the thin cytoplasmic projections as of the endothelial cells. The edge of the cytoplasmic sheet of the endothelial cell comes in contact with the sides of the Kupffer cell, without forming a terminal bar and desmosome. This relationship between the Kupffer and the endothelial cells closely resemble that between the large and the small epithelial cells lining the alveolar surface of the lung (Iто and Shibasaki 1965). 2) The Kupffer cells protrude numerous microvilluslike projections or pseudopods into the sinusoidal lumen and occasionally a few similar but shorter projections into the Disse's space as already noted by YAMAGisHi (1959). The endothelial cell sheets, on the contrary, are completely devoid of processes except for occasional microvillous projections protruded exclusively into the sinusoidal lumen ; in these cytological aspects, the Kupffer cells and endothelial cells also resemble the large and small alveolar epithelial cells of the lung respectively. 3) In comparison with the endothelial cells, the Kupffer cells, as revealed also by YAMAGISH (1959), contain a well developed large Golgi complex, a prominent agranular endoplasmic reticulum composed of enormous vesicles of various sizes and numerous mitochondria, but a poor granular endoplasmic reticulum and sparse ribosomes, both of which are better developed and more numerous in the endothelial 
cells. The above mentioned morphological differences between the Kupffer and the endothelial lining cells have caused us to describe both cells with provisional designation of two different cell types. We know, due to the previous light microscopic and histogenetic studies carried out by our co-workers (TAHIRA 1958, YAMAGishi 1958, Ito, TANAKA and Nemoto 1960), that the Kupffer cells may arise in the embryonic sinusoidal wall from the endothelial lining cell, and do believe with many recent authors that both types of cell represent only two different functional states of one and the same cell lineage. Nevertheless, we do not completely agree with authors who utterly deny the application of two different designations, "Kupffer cell" and "endothelial lining cell." These nomenclatures are convenient for the indication of two morphologically different functional states of the so-called "Kupffer cell" in the broader sense.

In the physiological livers from postnatal individuals it is difficult to detect the transformations of endothelial cells into Kupffer cells ; for this purpose, the extensive increase in volume of the perikarya of the endothelial cells must first of all be proved. RouILLER et al. (1963) have pointed out that the electron microscope has not definitively resolved the problem of the transformation of endothelial cells into Kupffer cells, although they (Nigolescu and Rouiller 1967) afterward could demonstrate the transitional forms between both cells in "zymosan" administered rats.

The constant elements found in the perisinusoidal or Disse's space are abundant microvilli protruded from the hepatocytes, reticular or collagen fibrils and fibers, "fat-storing cells" and bundles of unmyelinated nerve fibers. They are arranged in a narrow space showing intimate topographical relationships.

Since the discovery by FAwceTt (1955), the microvilli of the hepatocytes protruded into the Disse's space have been observed by many authors (RÜTTNER and Vogel 1957, Wassermann 1958, Hashimoto et al. 1958, Yamagishi 19.59, Cossel 1959 a, c, Horiughi 1960, Steiner 1961, Wood 1963, Tanikawa et al. 1965, Kuhn and Olivier 1965 etc.). The present observations on the microvilli of normal human hepatocytes agree on the whole with those reported by previous authors mentioned above. WASSERMANN (1958) proposed, that some of the microvilli are closely attached to the endothelial lining, but this finding was considered by Gossec (1959c) as an artifact; we also did not confirm the attachment of the microvilli either to the endothelial lining or to the fat-storing cells in normal human livers. RüTtNer and VogeL (1957) and TAnikawa et al. (1965) postulated that the width of the Disse's space might be determined by the length of the microvilli of the hepatocytes; this view, however, does not agree with Cossel's opinion (1959c) that the width of the Disse's space might depend on the amount of fluid retained in it, but never on the length of the microvilli. The microvilli may be the metaplasmic ultrastructure of the hepatocyte which mainly participate in the functions of the hepatocyte being situated at the blood-tissue barrier of the liver. Therefore the possible functional significances like the maintenance of the Disse's space, the supporting of the endothelial lining of the sinusoid and others should be less essential for them.

The fibrillar components corresponding to what had been described by light microscopy as reticular or lattice fibers have been described by electron microscopy under the name of either collagen or reticular fibers (RüTTNER et al. 1957, WASSERmann 1958, Yamagishi 1959, Cossel 1959 a, b, c, Schmidt 1960, Horiughi 1960, 
Steiner 1961, Wood 1963, Tanikawa et al. 1965, Kuhn and Olivier 1965, BronfenMAJER et al. 1966, Sahnack et al. 1966,etc.). All these workers have proved that they are represented by bundles of fibrils (microfibrils or Elementarfibrillen). But it has also been noted that collagen fibrils may occur singly or in small groups (Wood 1963 etc.). According to Steiner (1961) and Wood (1963) collagen fibers are most numerous at the periphery of the lobules or in the vicinity of the portal tract. All these electron microscopic findings reported by previous authors have been confirmed by the present study. In normal human livers examined there occur in the perisinusoidal space considerable amounts of variably thick collagen fibers oriented in various directions. In the areas, where the thick fibers occur in the perisinusoidal space, the microvilli of the hepatocytes are reduced in number or in length and sometimes disappear almost completely. Among the fibrils there is recognized an electron opaque homogeneous or minutely fibrillar material binding the fibrils with each other into bundles. Single fibrils or those making small groups, however, can occur among the microvilli and just beneath the endothelial lining indicating the innermost boundary of the perisinusoidal space. Neither fibrils nor fibers are distributed in the recesses. According to several workers the thickness of the fibrils composing the perisinusoidal reticular fibers varies from $200 \AA$ or less to 500 or $600 \AA$ (WASSERMANN 1958, Steiner 1961, Schnagk, Stockinger and Wewalka 1966, etc.), and the spacing of their cross striations has been reported to be $500 \AA$ (WASSERMANN 1958), $640 \AA$ (Steiner 1961, TAnikawa et al. 1965) and $650 \AA$ (Wood, 1963). The present study on normal human livers has proved that the diameter of the perisinusoidal fibrils varies from 700 to $300 \AA$, the average being approximately $500 \AA$, and that the cross striations show a periodicity of about $640 \AA$. According to KAJIKAwA (1956, 1959), the collagen fibrils show different thickness and periodicity in different stages of their development; the collagen fibrils in the subcutis of the normal adult mouse was measured by him to be about $1000 \AA$ or more in diameter and about $640 \AA$ in the periodicity of the striation. The perisinusoidal fibrils of the liver thus seem to be by far thinner than the collagen fibrils of the common connective tissue, though they show appoximately identical periodicity.

Since Yamagishi (1959) revealed for the first time by electron microscopy the "fat-storing cells" in the perisinusoidal space of the rabbit liver, they have been identified by a number of investigators with the electron microscope in several mammalian and human livers (Novikoff and Essner 1960, NAKane 1963, Rouiller et al. 1963, Tanikawa et al. 1965, Bronfenmajer, Sahaffner and Popper 1966, Sahnack, Stockinger and Wewalka 1966, Nigolescu aud]Rouiller 1967, etc.), though Bronfenmajer et al. and Sahnack et al. have proposed besides the original name the "fat-storing cell," the designation of "lipocyte" and "adventitielle Bindegewebszelle" respectively. Recently, Wood (1963) has observed the identical cells in the Disse's space of the calf liver and KunN and Olivier (1965) in the goat liver. Without knowing, however, the name of fat-storing cells they both termed these cells the "perisinusoidal cells." All the investigators mentioned above have confirmed at least one of the two essential characteristics of the fat-storing cells that they are located in the perisinusoidal space including the recessus being separated by the endothelial lining from the sinusoid and that they contain in cytoplasm fat droplets. Two Japanese authors MAtsuo (1959) and HoriUchi (1960), who observed by electron 
microscopy the hepatic sinusoidal wall, could not confirm the presence of the fatstoring cells in the Disse's space, though MAtsuo recognized, according to his description, the fat-droplet containing endothelial cells some of which were in fact within the perisinusoidal space.

The present electron microscopic study on the fat-storing cells in normal human livers has been able to add some new data to the knowledge on the fine structure of these cells.

Although no previous workers paid attention to the basement membrane of the fat-storing cells we could confirm the complete absence of it around these cells.

The fat-storing cells send out, contrary to the endothelial cells, a considerable number of cytoplasmic processes into the perisinusoidal space which surrounds them. This has been noted by a few previous workers like Yamagishi (1959), Wood (1963) and Schnack et al. (1966). The processes protruded towards the hepatocytes are microvillus-like in shape and interlace with the microvilli from the hepatocytes. More important, however, are those which are sent out from the surface facing the endothelial lining of the sinusoid, which we termed "subendothelial processes." About these processes we have already discussed in the paragraph of the endothelial lining of the sinusoid. Here we may add only one evidence that occasional subendothelial processes contain, as Schnack et al. (1966) reported, fat droplets.

The fat-storing cells and the hepatocytes are widely separated by the perisinusoidal space containing microvilli and reticular fibers, but on occasion they come in close contact even in a considerable length; there remains an intercellular slit about $200 \AA$ in width. This intimate connection between fat-storing cells and hepatocytes may probably be responsible for the direct communication between the both cell types.

In the cytoplasm of the fat-storing cells, besides fat droplets, a Golgi complex near the nucleus, small and sparse mitochondria, granular endoplasmic reticulum and free ribosomes were observed by previous investigators (YAMAGISHI 1959, NAKANE 1963, Bronfenmajer et al. 1966, Sahnagk et al. 1966). All the workers have denied the occurrence of the cytological signs suggesting a phagocytic activity in these cells. As to the occurrence of the lysosomes, however, there are opinion divergencies. Bronfemajer et al. (1966) recognized in their electron microscopic study on normal and diseased human livers neither materials engulfed by phagocytosis nor lysosomes in the fat-storing cells. SaHnack et al. (1966), on the contrary, confirmed, though only rarely, the presence of lysosomes. Novikoff and Essner (1960) did not completely deny the occurrence of the lysosomes in the fat-storing cells acknowledging that these cells differ from active Kupffer cells in lacking both the enlarged lysosomes with high acid phosphatase activity and the high ATPase activity in the plasma membrane. In the present study we could reveal in the fat-storing cells of the normal human liver a few small dense bodies bounded by a smooth limiting membrane which surely correspond to small lysosomes. However, some of them were difficult to be distinguished definitely from small immature fat droplets.

Though Yamagishi (1959) demonstrated the centriole located near the Golgi apparatus in the perikaryon of the endothelial lining cell of the rabbit hepatic sinusoid, it has never been observed in the fat-storing cell. In this study we encountered frequently the diplosome located within the Golgi complex of the fat-storing cells. 
In addition, we have evidenced fortunately for the first time that one of the paired centrioles of the diplosome is transformed into the basal body of a single cilium sent into the Disse's space.

That the fat-storing cells contain glycogen in cytoplasm has been proved by ITO, TAhira and Tsunoda (1953) and Tsunoda (1955) by means of the light microscopic histochemistry, but by the electron microscopy it has been revealed only by SaHnAck et al. (1966) ; they reported that only sparse glycogen particles were demostrated in the fat-storing cells of the human liver. TAnikawa et al. (1965) could not detect the glycogen particles in the fat-storing cells of the rat. In this study we could not also reveal darkly stained glycogen particles in the human fat-storing cells though only in one cell minute electron lucent areas, which may probably correspond to the unstained glycogen particles, were demonstrated along the canaliculi of the agranular endoplasmic reticulum. The biopsy specimens which were used in this study were taken from patients who had been kept in starvation for a long time before the operations. The storage glycogen in various tissues and organs is thus believed extensively reduced in amount and the same might be possibly the case of the glycogen deposit in the fat-storing cells.

The prominent pinocytotic activity in the fat-storing cells of the normal human liver was confirmed for the first time in the present study. Along the surface plasma membrane, numerous pinocytotic invaginations and vesicles occurred and among them a few coated ones were observed. In this respect, the fat-storing cells predominate over the endothelial lining cells of the hepatic sinusoid, whereas the latter usually possess large vacuoles namely phagosomes suggesting the phagocytic activity which are completely lacking in the former. The numerous pinocytotic invaginations and vesicles undoubtedly suggest the vigorous material transport and metabolic activity proceeding in these cells. As revealed already by light microscopic and histogenetic studies of the human, rabbit and chick livers carried out by TAHIRA (1958), Yamagishi (1958) and Ito, Tanaka and Nemoto (1960), the fat-storing cells and the sinusoidal endothelial cells originate alike from the mesenchymal cells situated in the wall of the primitive sinusoids. From the beginning of the development they are aligned side by side in two rows lining the sinusoid and differentiate into two directions. It seems thus easy to understand that both cells possess several similarities and, at the same time, certain differences in their ultrastructures.

Though it has been revealed by light microscopy that the fat-storing cells of the human liver contain as a rule numerous small fat-droplets which are blackened by osmic acid contained in the fixing fluid (Iто and Nemoto 1952), most of the fat droplets appeared in this study as vacuoles either with electron transparent content or quite empty; osmium-blackened content occurred only exceptionally. In ultrathin sections the fat droplets contained in a fat-storing cell was in general small in number and the occurrence of a considerable number of droplets was rare, the maximum counted being ten; in this respect, we agree with Bronfenmajer et al. (1966). The question, whether fat droplets of the fat-storing cells possess a limiting membrane or not, is quite open. The above mentioned authors have noted that the droplets never coalesce. In this study we also often recognized two closely adjoined fat droplets, not coalesced but separated by a thin membrane-like septum. Moreover, it was proved that each fat droplet was bounded by a weak but fairly distinct smooth 
limiting membrane. This observation was facilitated by the fact that the droplets in question appeared in this study as clear vacuoles as mentioned before. The question, whether fat droplets of the white and brown adipose cells possess a limiting membrane or not, has recently been discussed by some investigators. In their electron microscopic study on the brown adipose tissue in newborn rabbits LiNDBERG et al. (1967) proposed that the fat droplets do not seem to have the distinct limiting membrane suggested earlier. PICARD et al. (1966), on the other hand, maintained that the lipid droplets of the interscapular brown adipose cells in rats are enclosed permanently in a limiting membrane contrary to those of the white adipose cells which aggregate in the cytoplasmic matrix without any limiting membrane. WooD (1967) revealed, however, in his observation on the fat droplets in developing fat cells from chick bone marrow that they do not lie free in the cytoplasm, nor are they bounded by a membrane, but instead are encompassed by a highly ordered complex of small, $80 \AA$ thick filaments. He assumed that in oblique sections, superimposition of the images of adjacent filaments results in a more or less continuous line which resembles a membrane. In this study, however, we could not confirm his assumption, but believe that further detailed examinations should be made for solving the questions on this subject.

The present observation on the occurrence of a few smaller probably immature fat droplets $(0.3-1.0 \mu)$ which are somewhat electron opaque having more osmiophilic marginal zone to which sometimes osmiophilic granules adhere, may suggest that the synthesis of fat as well as the formation of fat droplets proceed in the fat storing cells.

Recently, PICARD et al. (1966) assumed in the study on the brown adipose tissue of the rat that the lipogenesis in the brown adipose cells may take place inside the vesicles of the smooth surfaced endoplasmic reticulum which has increased partially by the pinocytotic activity at the periphery of the fat cells. Oрніамво (1967), who also assumed a distinct bounding membrane limiting the lipid globules, proposed in the study of the lipogenesis in the fat body cells of the locust that the Golgi apparatus and the pinocytotic vesicles (pinosomes) including the bristle-coated vesicles may participate in the lipogenesis and the formation of the lipid globules. He observed far more pinocytotic vesicles in young or maturing fat body cells than in the cells of fully mature males. In this study we usually observed in the fat-storing cells the well-developed Golgi apparatus showing frequently an intimate topographic relationship with the fat droplets and with considerably numerous pinocytotic invaginations and vesicles including sparse bristle-coated ones. As to the lipogenesis in the fat-storing cells, we thus dared to postulate provisionally the following mechanism: The pinocytotic vesicles containing probably ingested precursors for lipid synthesis may migrate to the Golgi area where the fat synthesis may take place. As the result osmiophilic granules and small immature fat droplets may be formed. The latter may perhaps grow gradually into mature ones by additional fusions of osmiophilic granules. In this study we were, however, unable to evidence actually the formation of the lipid granules and the small immature fat droplets within or in close proximity to the Golgi complex.

As a result of numerous light microscopic investigations on the fat-storing cells carried out by ITO and his co-workers, it was confirmed that there occur so-called 
empty fat-storing cells devoid of fat droplets especially in the central zone of the hepatic lobules. In the present study we occasionally encountered empty cells in the Disse's space of normal human livers which showed several ultrastructural characteristics identical with those of the typical fat-storing cells. In our opinion the pericytes observed by Sahmidt (1961), Horiughi (1960) and Tanikawa et al. (1964) in the Disse's space probably correspond to the empty fat-storing cells. Several morphological properties of the pericytes pointed out by Horiuchi, e. g. occurrence of a relatively large nucleus and a few organelles as well as the absence of glycogen particles and phagocytosed materials, agree with those of the empty fat-storing cell. In the present study we could identify in the Disse's space no pericytes other than the empty fat-storing cells. As described above, the occasional round cells of an unknown nature found in the Disse's space are quite different from the pericytes and from the empty fat-storing cells : they seem probably to be one type of the hematopoietic cell.

It is difficult to determine the exact population density of the fat-storing cells in the hepatic lobules. In the cases or places of the hepatic lobules in which the fat-storing cells possess a large amount of fat droplets, they are easily identified and taken for as if they have increased in number. On the contrary, the empty fat-storing cells and those loaded with only a few fat droplets may easily be overlooked and judged as if they have diminished in number.

Several light microscopic investigations carried out by Іто and his co-workers have proved that the fat-storing cells distributed in the intermediate and the peripheral zone of the hepatic lobules contain in general a considerable amount of fat droplets, whereas those found in the central zone, as described above, are empty or contain a small amount of droplets. When the droplets in the cells intensively increase in amount, those distributed in the central zone become heavily loaded with droplets and may result a sham increase of these cells. On the basis of the above mentioned data acquired by several light microscopic observations, we must criticize the population density of these cells in the hepatic lobules. SAFran and Schaffner (1967) reported that in the chronic congestion of the human liver the lipocytes (fatstoring cells) were most numerous in the zone adjacent to the portal tract. Schnack et al. (1966), Bronfenmajer et al. (1966) observed in some cases of pathological human livers the increase of the fat-storing cells. Nigolescu and Roulller (1967) encountered more numerous fat-storing cells in the livers of the "zymosan" administered rat than in those of the control animals. In their valuable and important article on the lipocytes (fat-storing cells) of the normal and pathological human livers, Bronfenmajer et al. (1966) counted the number of these cells in comparison with that of the hepatocytes. According to them, in the normal liver three to five fat-storing cells were found in the field of 60 to 100 hepatocytes, namely one lipocyte was found for every 20 hapatocytes and this ratio was smaller than that of the macrophages being one third to one fourth of that of the latter. Yokochi (1956, unpublished data), one of the co-workers of ITO, counted the number of the fatstoring cells distributed in one square millimeter of the hepatic lobules in about $4 \mu$ thick sections of the livers from several mammals, human beings and the chick. According to his results, the number of the cells was 139 in the normal human liver, about 105 in the calf, 151 in the goat, 171 in the pig, 201 in the horse, 152 in the dog 
and 514 in the chick.

By numerous light microscopic examinations on the fat-storing cell done by Іто and his co-workers, it has been proved that their most essential functional significance consists in that they synthesize and store lipid to supply it in response to the demand of the hepatocytes. As doubted by Bronfenmajer et al. (1966), it seems not probable that the actual transfer of fat droplet might occur from the fat-storing cells to the hepatocytes; the lipid might be supplied perhaps in an invisible state to the latter. For this purpose the existence of the above described close contact of the even surfaces of the both cell types is profitable, in which two plasma membranes lining the adjoining cell surfaces are juxtaposed with a narrow cleft about $200 \AA$ in width.

In relation to the fat storing, the storing of the fat-soluble vitamin $\mathrm{A}$ in the fatstoring cells seems to be possible. Nakane (1963) and Bronfenmajer, Sahaffner and Popper (1966) inclined to accept the view that the fat-storing cells or lipocytes should store also vitamin A. Their view concerning the vitamin A storing of the fat-storing cells is based on the findings obtained by Popper (1944) who studied the localization of vitamin A by means of the fluorescence microscopy in ultraviolet light with a wave-length of $328 \mathrm{~m} \mu$. He mainly revealed the bright green rather quickly fading fluorescence of vitamin A both in the fine fat droplets contained in the Kupffer cells and in those found in the hepatocyte borders adjacent to the sinusoid. In this way he confirmed the important role of the Kupffer cells in fat and vitamin A metabolism. Under experimental conditions he observed that the vitamin A stored in the Kupffer cells is the last to be depleted and the first to be repleted. According to our assumption, vitamin A-storing Kupffer cells and hepatocyte borders facing the sinusoid may be for the most part nothing but fat-storing cells located in the perisinusoidal space. As widely known, the Kupffer cells and the hepatocytes of the mammals, contrary to the fat-storing cells, do not possess fat droplets constantly in the normal conditions. The finding that the fat droplets deposited constantly in fat-storing cells do not completely disappear after long-term starvation and quickly reappear after feeding, was demonstrated already by the light microscopic observations of Ito, Okonogi, Satsuki, Nemoto and Kano (1952) and Satsuki (1953). Now we support in agreement with Nakane (1963) and BronFENMAJER et al. (1966) the view that the fat-storing cells should be the storing sites of vitamin A which may be furnished to hepatocytes to be utilized or destroyed there under circumstances.

The third possible function of the fat-storing cells is that concerning the intralobular fibrogenesis. Though WASSERMANN (1958) presented a hypothesis that the cells engaged in the formation of the reticular fibers distributed in the Disse's space must be the endothelial cells lining the hepatic sinusoids, Wood (1963) possessed some doubts on this view and drew attention to his perisinusoidal cells which may probably correspond to the fat-storing cells; he seemed inclined to ascribe the formation of collagen fibrils to these cells regarding them as either primitive reticular cells or fibroblasts. Recent electron microscopic observation of Sghnack, Stockinger and WEWALKa (1966) strongly supported the view of Wood. They termed the fat-storing cell in the Disse's space the "adventitielle Bindegewebszellen" They ascribed the formation of the collagen fibrils to these cells resembling the fibroblasts. By showing 
that, in the case of the accelerated fibrilogenesis, the cisternae of their granular endoplasmic reticulum remarkably increase and contain minutely filamentous material which seemingly corresponds to the precursors of collagen fibrils. Concerning the nature of the fat droplets contained in these cells, they raised the question whether they are physiological inclusion bodies or degenerative products. In the present study we have revealed some morphological findings supporting the view of the participation of the fat-storing cells in intralobular fibrilogenesis : First, the intimate topographical relationship between reticular or collagen fibers (fibrils) and the fatstoring cells must be noted. Both of them come in direct contact with each other, since the fat-storing cells do not possess any basement membrane; especially in the case when the fat-storing cells have indentations in the plasma membrane, the collagen fibrils are embraced in them making a small bundle or group. Second, the fat-storing cells possess commonly a well developed rough-surfaced endoplasmic reticulum, which is generally regarded as the site of fibrilogenesis in those cells like fibroblasts, osteocytes and chondrocytes. However, we could not, contrary to SaHNAGK et al. (1966), eonfirm the occurrence of the delated cisternae of the endoplasmic reticulum containing a finely filamentous material which may probably be precursors of the collagen fibrils. Thus the problem of the possible participation of the fat-storing cells in the intralobular fibrilogenesis is still hypothetical and requires further observations to be confirmed. The fourth function of the fat-storing cells is mechanical one; as mentioned above, they send out cytoplasmic processes (subendothelial processes) into subendothelial portion of the Disse's space, which are directed in parallel with the endothelial lining to reinforce the latter.

The factors which may control the amount of the fat droplets in the fat-storing cells seem to be manifold. Besides starvation, feeding, kind of diet or food, pathological and abnormal conditions etc. as well as hormonal and genetic factors must be taken into consideration (Novikoff and Essner 1960, Bronfenmajer et al. 1966). Recently, Gallahan, Hackett and Loringz (1967) reported in the observation of the livers from 11 patients with HurLen's syndrome the occurrence of the Kupffer cells packed with a large number of fat droplets and their increase in number after cortisone therapy. Without any doubt, these Kupffer cells are identical, as they themselves assumed, with the fat-storing cells (lipocyte of Bronfenmajer et al.). We confirmed in several cases of the liver from the hypophysis-deficient patients the maintenance of the fat droplets in the fat-storing cells (unpublished). Further examination on this field of research is necessary.

Recently Yamada (1965) has revealed fo the first time by electron microscopy unmyelinated nerve fibers encased by Schwann cytoplasm in the Disse's space of the mouse livers and observed the relations between the nerve fibers and the hepatocytes. He encountered possible nerve terminals which were naked lacking in the cover of Schwann cell and contacted with the hepatocytes directly. He found these nerve terminals usually in the indentations of the surface of the hepatocytes or embedded in the hepatocyte cytoplasm separated by a distinct plasma membrane; in the terminals there was recognized the accumulation both of mitochondria and synaptic vesicles, some of which were granular ones, but no density increase in the opposed plasma membrane. In the present study we have frequently encountered small bundles of unmyelinated nerve fibers encompassed by a Schwann cytoplasm 
in the Disse's space of normal human livers. These small unmyelinated nerves were distributed most frequently and freely in the Disse's space but occasionally in the indentation or hollow of the hepatocytes. In both cases the nerves contained vesiculated axons which probably corresponded to such expanded portions of the axons as described by previous authors (Honjin et al. 1965) as "vesiculated nerve processes" or "varicosities." They contain variable numbers of agranular synaptic vesicles intermingled frequently by a few granular ones; the axon plasma membrane becomes naked often for a variable extent giving up partially the covering of the Schwann cytoplasm and comes in direct contact with the microvilli of the hepatocytes. Occasional direct contact with the even surface of the fat-storing cells was also observed. In both cases the density increase in the opposed plasma membranes separated by a cleft was not confirmed. Contrary to the finding of YAMAdA (1965), the direct contact of the vesiculated axon with the even surface of the hepatocyte and the penetration of the naked axon into it were missed in normal human livers; further observations are required to answer the question whether such direct contacts between the hepatocyte and the vesiculated axon as demonstrated by YAMADA (1965) in mouse livers, may exist also in normal human livers. Though in his electron micrographs a nucleated portion of the Schwann cell was not visible, we could find it in the subendothelial portion of the Disse's space of the human liver.

\section{Summary}

In normal human livers obtained in surgical operations the sinusoidal wall has been observed with the electron microscope.

The "endothelial cells" and the "Kupffer cells" lining the sinusoid are regarded as two functional states of the same cell lineage and show alike the ultrastructures suggesting phagocytic activity. They differ from each other especially in that the endothelial cells consist of two distinct portions, the perikaryon and the sheet-like cytoplasmic extension, the latter occupying the major part of the sinusoidal lining, while the Kupffer cells are of simple rounded-up form bulking into the sinusoidal lumen; the endothelial cell sheets extend to the Kupffer cell body to contact with the latter. On the other hand, the marginal ends on the neighboring endothelial sheets may overlap like roof tiles. In both connections there occur no junctional structures like terminal bars and desmosomes.

The endothelial lining of the sinusoid which is discontinuous because of the presence of intracellular gaps or pores and lacking in general in continuous basement membrane, is as a rule a simple layer. Frequent figures of stratified endothelial sheets are caused for the most part by the occurrence of subendothelial fat-storing cells which extend thin processes as if to reinforce the endothelial lining. The perisinusoidal or Disse's space is filled with blood plasm filtered through the discontinuous endothelial lining of the sinusoid. This space which represents the blood-tissue barrier of the liver contains, besides abundant microvilli of the hepatocytes and collagen or reticular fibers and fibrils, fat-storing cells, unmyelinated nerve fibers with their Schwann cells and occasional round, probably hemopoietic cells. The fat-storing cells are constant residents in the Disse's space and frequently extend into the recesses between the hepatocytes. They are lacking in their own basement mem- 
brane and contact directly with the collagen fibers, which are sometimes embraced in the invaginations of their plasma membrane. They send out a considerable number of cytoplasmic processes in the Disse's space which interlace with the microvilli of the hepatocytes. Glose contacts between the even surfaces of the fat-storing cells and of the hepatocytes are occasionally encountered.

The fat-storing cells possess relatively well-developed Golgi complex containing a diplosome, sparse small mitochondria, fairly well-developed elements of granular endoplasmic reticulum, small lysosomes, glycogen particles and, occasionally, a single cilium into the Disse's space which arises from one of the paired centrioles of the diplosome. Though the fat-storing cells exhibit no cytological signs indicating a phagocytic activity, many invaginations of the plasma membrane and vesicles including the bristle-coated ones are found along their free surfaces suggesting a vigorous pinocytotic activity. As constant and characteristic cytoplasmic inclusion bodies, the fat-storing cells contain small fat droplets, each of which (about $2 \mu$ in diameter) is bounded by a weak limiting membrane and does not fuse with each other into larger ones. The fat-storing cells may occasionally contain no fat droplets; the "pericytes" observed by some authors in the Disse's space, probably correspond to these empty fat-storing cells.

The following possible functions of the fat-storing cells are proposed: 1) Fat synthesis and fat-droplet formation, 2) the storing of fat droplet and fat-soluble vitamin A, 3) the participation in intralobular fibrilogenesis and 4) the reinforcement of the endothelial lining of the sinusoid by sending subendothelial processes.

\section{正常なヒトの肝藏の類洞壁と脂肪摂取細胞の電子顕微鏡的研究（内容自抄）}

類洞を囲む内皮細胞之星細胞は同じ細胞系の異なる機能状態と考えられ，乙むに貪食能 を示す微細構造をもつ. 両者の形態学的相違として内皮細胞では核周囲部とそれからの びる細胞質の薄膜状突起とが分化し，後者が類洞の大部分を团むが，星細胞は細胞質に富 む丸まった細胞で類洞腔へ強く乫出する，從って内皮細胞の薄膜状乫起の末端は星細胞に 達しそれと接する。また，隣接する内皮細胞の薄膜状突起の末端は互いに屋根瓦状に重疊 して接触する。いずれの場合にも接触部に閉鎖堤やデスモゾームは見られない.

内皮細胞の薄膜状突起は一般に典型的な基底膜を伴なわず，また不定間隔をおいて細胞 内断裂または孔があるために不連続性である。類洞を囲むとの薄膜状突起は原則的には単 層である，重層して見えることがあるが，大部分は，内皮細胞層を補強するために脂肪捸 取細胞が派出する内皮下突起 (subendothelial processes) によって生ずる所見と考えられ る.

類洞周囲腔 (Disse 腔) は不連続性の内皮細胞層と肝細胞の類洞面との間に成立し,肝臟 の血液-組織関門として，そこには多数の肝細胞微䋐毛，膠原 (ないし細網) 線維 おょよび原 線維のほかに脂肪摄取細胞, Schwann 細胞に包まれた無䯣神経線維，および造血細胞と 思われる円形細胞が見られ，乙れらはすべて内皮細胞孔を通じて侵入する血漿にひたされ て存在する，脂肪摂取細胞は Disse 腔の常在性要素で，類洞面からは常に内皮細胞層によ ってへだてられ，基底膜を伴なわないので翏原線維と直接接しており，時に形質膜の陥凹 の中に膠原線維を抱く。乙の細胞の細胞質突起は肝細胞の微綫毛と交錯する。乙の細胞と 
肝細胞との間の平滑面による密接な接能が時に認められる。

脂肪楞取細胞は，よく発達したゴルジ装置，双中心子，少数の小さい系粒体，よく発達 した粗面小胞体，小さいリゾゾームとグリコゲン顆粒をむつ。また時に双中心子の一方の

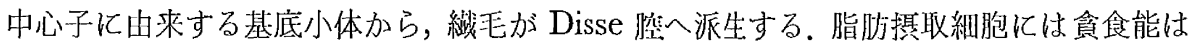
見られないが，邽盛な胞飲作用を示す多くの小胞と北質膜の陷凹が認められ，少数の屯の は “coated”である。ヒトの脂肪㩒取縕胞の恒常的，特異な包含体は約 $2 \mu$ 大の数㑑の脂 肪滴である。乙れらは薄弱な限界膜をもち，互に融合して大做とならない。しかし，時

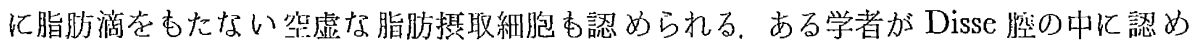
た“pericytes”は扔そらくこの架虚な脂肪摄取綝胞に相当する。

脂肪掑取細胞の機能的意義は次の 4 項目に要約される。1) 脂肪合成拉よび脂昉榈形成，

2) 脂肪滴および脂溶性ビタミンA の䝪哉，3）朋小䐑内線維刓成への関与，4）内皮下突起 の派出による類洞内皮細胞層の補強。

\section{References}

Aterman, K.: The structure of the liver sinusoids and the sinusoidal cells. In: (ed. by) Gh. Rouiller: The liver. Morphology, biochemistry, physiology. New York, Academic Press, 1963. (Vol.1, p. 61-136).

Bennett, H. S., J. H. Luft and J. G. Hampton: Morphological classification of vertebrate blood capillaries. Amer. J. Physiol. 196:381-390 (1959).

Bronfenmajer, S., F. Schaffner and H. Popper: Fat-storing cells (lipocytes) in human liver. Arch. Pathol. $82: 447-453$ (1966).

Büttner, D. W. and E. Horstmann: Das Sphaeridion, eine weit verbreitete Differenzierung des Karyoplasma. Z. Zellforsch. 77 :589-605 (1967).

Gallahan, W. P., R. L. Hackett and E. Lorincz: New observations by light microscopy on liver histology in the Hurler's syndrome. Arch. Pathol. 83 :507-512 (1967).

Cossel, L.: Elektronenmikroskopische Befunde an Lebersinusoiden und -epithelien bei verschiedenen Funktionszuständen der Leber. Verh. Deut. Ges. Pathol. 43 : 204-208 (1959a).

- : Beitrag zur Ultrastruktur der Blutgewebegrenze in der Leber. Beitr. pathol. Anat. allg. Pathol. $120: 153-158$ (1959b).

: Elektronenmikroskopische Untersuchungen zur Frage des Disseschen Raumes in der Leber. Klin. Wochenschr. $37: 743-753$ (1959c).

: Über den submikroskopischen Zusammenhang der interzellulären Räume und Sinusoide in der Leber. Z. Zellforsch. $58: 76-93$ (1962).

Fawcett, D. W.: Observation on the cytology and electron microscopy of hepatic cells. J. Nat. Gancer Inst. 15 : 1475-1512 (1955).

Hampton, J. G.: An electron microscopic study of the hepatic uptake and excretion of submicroscopic particles injected into the blood stream and into the bile duct. Acta anat. $32: 262-291$ (1958).

Hashimoto, M., T. Onoe and S. Tutumi : Electron microscopic studies on the hepatic sinusoid of the mouse (Japanese text). Electron microscopy $6: 109-111$ (1958).

Honjin, R., A. Takahashi and Y. Tasaki: Electron microscopic studies of nerve endings in the mucous membrane of the human intestine. Fol. anat. jap. $40: 409-427$ (1965).

Horiuchi, T.: Electron microscopic observation on the sinusoid of the normal rabbit liver. Kobe J. med. Sci. 6:185-210 (1960).

Ito, T. und M. Nemoto : Über die Kupfferschen Sternzellen und die "Fettspeicherungszellen" ("fat- 
storing cells") in der Blutkapillarenwand der menschlichen Leber. Fol. anat. jap. 24 : 243-258 (1952).

Ito, T., T. Okonogi, S. Satsuki, M. Nemoto und K. Kano: Studien über die "Fettspeicherungszellen" der Leber bei verschiedenen Krankheiten (Japanese text with German abstract). Arch. bistol. jap. 4 : 103-120 (1952).

Ito, T., S. Satsuki und R. Tahira: Über die Beziehung der Fettspeicherungszellen und der Gitterfasern in der Leber (Japanese text with German abstract). Arch. histol. jap. 5 : 477-484 (1953).

Ito, T., R. Tahira und K. Tsunoda : Über das Vorkommen des Glykogens in den "Fettspeicherungszellen" (fat-storing cells) der normalen Kaninchenleber (Japanese text with German abstract). Arch. histol. jap. 5:541-554 (1953).

Ito, T., Y. Tanaka und M. Nemoto: Histogenetische Untersuchungen über die Leber des Hühnchens während der Brütung und'nach der Ausbrütung mit besonderer Berücksichtigung der Fettspeicherungszellen (fat-storing cells) und der Mitochondrien der Leberzellen (Japanese text with German abstract). Arch. histol. jap. 19:565-565 (1960).

Ito, T. und S. Shibasaki : Morphologische Studien über die Lunge bei der Fledermaus : Elektronenmikropische Beobachtung der Alveolarwand (Japanese text with German abstract). Arch. histol. jap. $25: 491-531$ (1965).

Kajikawa, K.: Studies on the formation of the collagen fiber (Japanese text). Juzen-Igakukai-Zasshi $62: 465-475$ (1959).

Kuhn, N. O. and M. L. Olivier: Ultrastructure of the hepatic sinusoid of the goat Capra hircus. J. Cell Biol. 26 : 977-979 (1965).

Lindberg, O., J. de Pierre, E. Rylander and B. A. Afzelius : Studies of the mitochondrial energytransfer system of brown adipose tissue. J. Cell. Biol. 34:293-310 (1967).

Matsuo, U.: Electron microscope studies on the reticuloendothelial system of the normal rabbit's liver and formation of epitheloid tubercle. Kobe Igaku Kiyo $15: 265-276$ (1959).

Nakane, P. K. : Ito's fat-storing cell of the mouse liver. Anat. Rec. 145 : 265-266 (1963).

Nicolescu, P. and Ch. Rouiller: Beziehungen zwischen den Endothelzellen der Lebersinusoide und den von Kupfferschen Sternzellen. Elektronenmikroskopische Untersuchung. Z. Zellforsch. 76 : 313-338 (1967).

Novikoff, A. B. and E. Essner: The liver cell (a review). Some new approach to its study. Amer. J. Med. $29: 102-131$ (1960).

Odhiambo, T. R.: The fine structure and histochemistry of the fat body in the locust, Schistocerca gregaria. J. Cell Sci. $2: 235-242$ (1967).

Parks, H. F.: The hepatic sinusoidal endothelial cell and its histological relationships. Electron microscopy. Proc. Stockholm Conference, Sept. 1956 (cited by Wassermann, 1958).

Picard, D., F. Tasso and G. Cotte: Aspect ultrastructural de la lipogénèse dans le tissu adipeux brun. Z. Zellforsch. 69:260-273 (1966).

Popper, H.: Distribution of vitamin A in tissue as visualized by fluorescence microscopy. Physiol. Rev. 24 : 205-224 (1944).

Rouiller, Ch. and A. -M. Jézéquel: Electron microscopy of the liver. In: (ed. by) Ch. Rouiller: The liver. Morphology, biochemistry, physiology. New York, Academic Press, 1963. (Vol. 1, p. 195-264).

Rüttner, J. R. und A. Vogel: Elektronenmikroskopische Untersuchungen an der Lebersinusoidwand. Verh. Deut. Ges. Pathol. 41 : 314-320 (1957).

Safran, A. P. and F. Schaffner: Ghronic passive congestion of the liver in man. Electron microscopic study of cell atrophy and intraloblar fibrosis. Amer. J. Pathol. 50 : 447-463 (1967).

Satsuki, S. : Über die Veränderung der Leber- und der Fettspeicherungszellen (fat-storing cells) in der Leber bei den Hungerkaninchen (Japanese text with German abstract). Arch. histol. jap. $6: 33-48$ (1953).

Schmidt, F. C.: Elektronenmikroskopische Untersuchungen an den Sinusoidwandzellen (Kupfferschen Sternzellen) der weißen Maus. Anat. Anz. $108: 376-387$ (1960). 
Schnack, H., L. Stockinger und Wewalka : Die Bindegewebszellen des Disseschen Raumes in der menschlichen Leber bei Normalfällen und pathologischen Zuständen. Wien. klin. Wochenschr. $78: 715-724$ (1966).

Steiner, J. W.: Investigations of allergic liver injury. I. Light, fluorescent and electron microscopic study of the effects of soluble immune aggregated. Amer. J. Pathol. 38:411-436 (1961).

Tahira, R.: Histogenetische Untersuchungen über die Leber bei Menschenfoeten mit besonderer Berücksichtigung der Fettspeicherungszellen (fat-storing cells) (Japanese text with German abstract). Arch. histol. jap. 14:495-544 (1958).

Tanikawa, K., K. Yoshimura and Sh. Gohara: Fine structure of reticuloendothelial cells in the normal rat liver: Morphological classification. Kurume med. J. 13 : 139-147 (1965).

Tsunoda, K.: Über das Vorkommen des Glykogens in den Fettspeicherungszellen (fat-storing cells) der menschlichen Leber (Japanese text with German abstract). Arch. histol. jap. $7: 565-572$ (1955).

Wassermann, F.: The structure of the wall of the hepatic sinusoids in the electron microscope. $\mathrm{Z}$. Zellforsch. 49:13-32 (1958).

Wood, R. L.: Evidence of species difference in the ultrastructure of the hepatic sinusoid. Z. Zellforsch. 58 : 679-692 (1963).

Wood, E. M.: An ordered complex of filaments surrounding the lipid droplets in developing adipose cells. Anat. Rec. $157: 437-448$ (1967).

Yamada, E.: Some observations on the nerve terminal on the liver parenchymal cell of the mouse as revealed by electron microscopy. Fol. anat. jap. 40 : 663-677 (1965).

Yamagishi, M.: Electron microscope studies on the fine structure of the sinusoidal wall and fatstoring cells of rabbit livers (Japanese text with English abstract). Arch. histol. jap. 18:223261 (1959).

- : Untersuchungen über die embryonale und postnatale Histogenese der Kaninchenleber mit besonderer Berücksichtigung der Entwicklung der Fettspeicherungszellen (fat-storing cells) (Japanese text with German abstract). Arch. histol. jap. 15 : 25-68 (1958). 